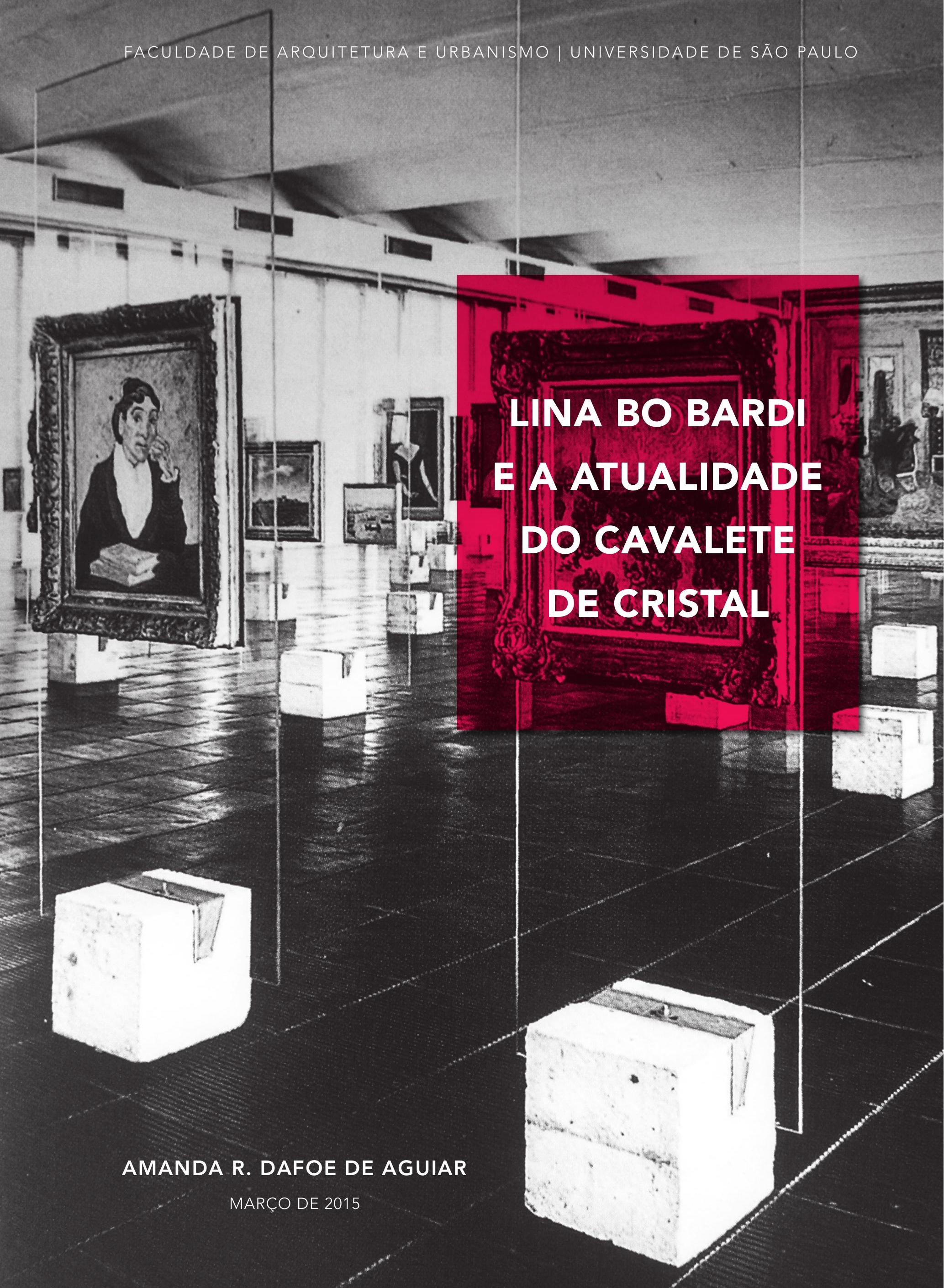




\section{LINA BO BARDI}

E A ATUALIDADE DO CAVALETE DE CRISTAL

Dissertação apresentada à Faculdade de Arquitetura e Urbanismo da

Universidade de São Paulo para a obtenção do título de Mestre na área de concentração Design e Arquitetura.

AMANDA RUTH DAFOE DE AGUIAR

Orientadora

PROF a DRA. CLICE DE TOLEDO SANJAR MAZZILLI 
AUTORIZO A REPRODUÇÃO E DIVULGAÇÃO TOTAL OU PARCIAL DESTE TRABALHO, POR QUALQUER MEIO CONVENCIONAL OU ELETRÔNICO,

PARA FINS DE ESTUDO E PESQUISA, DESDE QUE CITADA A FONTE.

E-MAIL DA AUTORA: amanda.dafoe@gmail.com

Aguiar, Amanda Ruth Dafoe de

A282L Lina Bo Bardi e a Atualidade do Cavalete de Cristal / Amanda Ruth Dafoe de Aguiar. São Paulo, 2015.

$$
142 \text { p. : il. }
$$

Dissertação (Mestrado - Área de Concentração: Design e

$$
\text { Arquitetura) - FAUUSP. }
$$

Orientadora: Clice de Toledo Sanjar Mazzilli

1.Museografia 2.Museus de arte 3.Design 4.Instituições culturais 5.Curadoria 6.Identidade cultural 7.Bardi, Lina Bo, 1914-1992 I.Título

CDU 7:069.02 
ISc

The. 3.

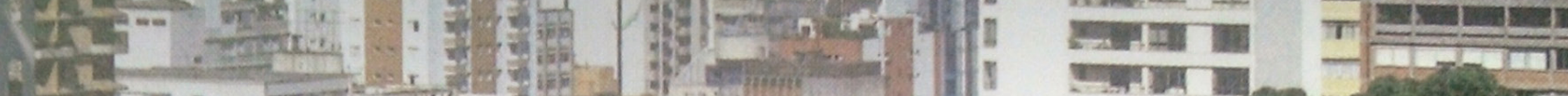
는:

Agradeço a Adriano Pedrosa, André Vainer, Guilherme Wisnik, Luís Antonio Jorge, Marcelo Suzuki, Martin Corullon, Olivia de Oliveira e Renato Anelli, pelos generosos diálogos que muito acrescentaram a essa pesquisa. Ao querido André Stolarski - in memorian -, culpado pelos caminhos profissionais que escolhi trilhar. À minha orientadora Clice Mazzilli, pela confiança que depositou em mim. À querida Luiza Proença, pelas importantes pontes estabelecidas. Agradeço, também, aos amigos Ana Chun, Ana Montag, Leila Shöntag, Maria Catarina Duncan, Marcello Dantas, Melina Valente, Renata Moura, Rodrigo Vilella, Tissa Kimoto, Tobi Maier e Vitor Mizael pelo apoio oferecido das mais variadas formas durante esse processo. À minha mais-que-mãe, Ruth, e meu irmão querido, Alexandre - obrigada sempre e por tudo! E Fernando Oliva - sem você ao meu lado, isso não teria sido possível. 


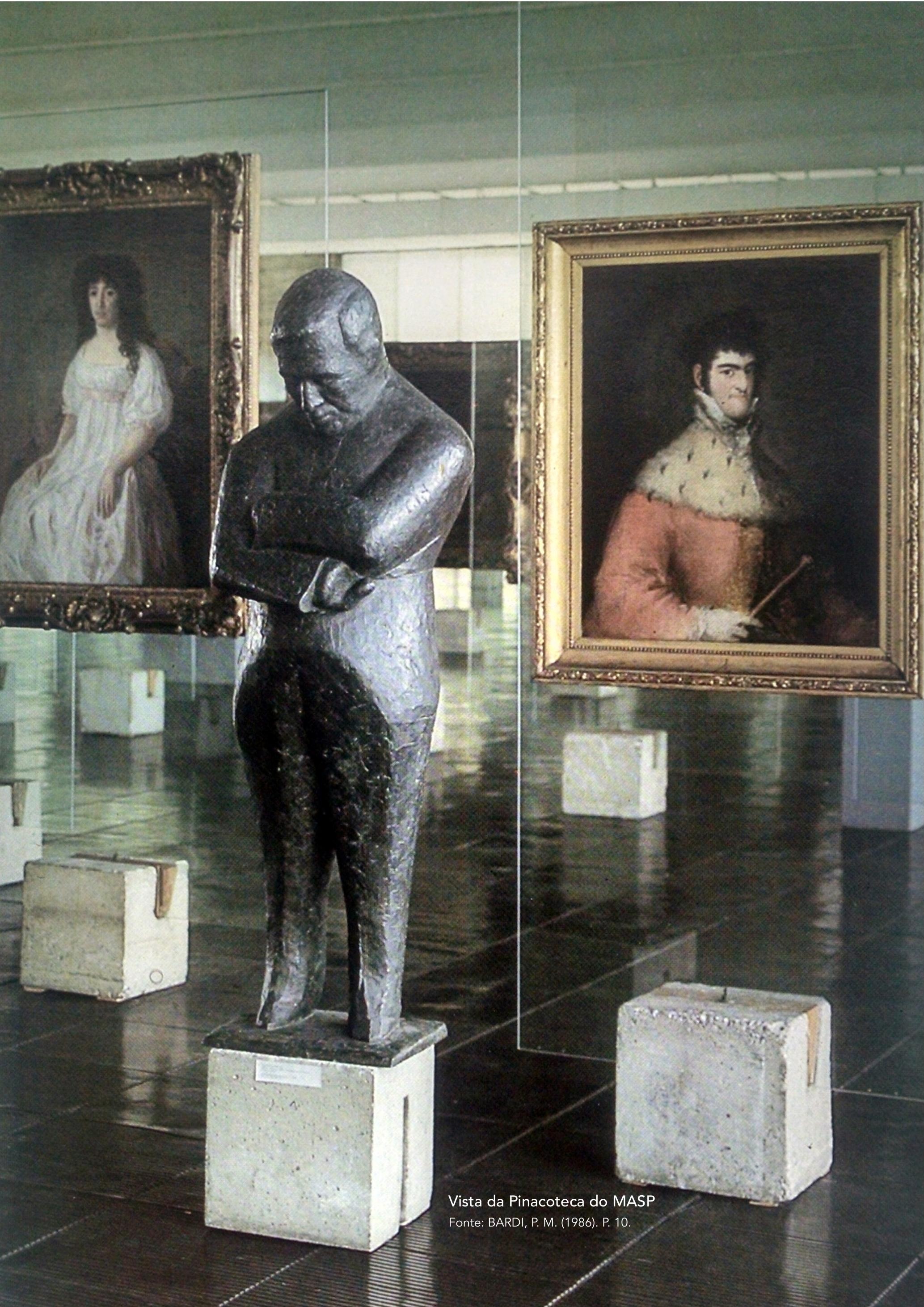

\section{RESUMO}

Este projeto busca analisar o Cavalete de Cristal, aparato expositivo criado no fim da década de 1950 pela arquiteta ítalo-brasileira Lina Bo Bardi para ser a peça central da composição da expografia do Museu de Arte de São Paulo, o MASP. A pesquisa evidenciará que o design dessa peça - a partir da solução espacial para a qual foi planejada e do discurso curatorial nela embutido - criou uma gramática expográfica singular que, mesmo após sua extinção em 1996 ainda reverbera de maneira potente em discussões internacionais sobre os desafios da apresentação da arte em museus na atualidade. Esta pesquisa reflete a necessidade de se voltar o olhar para a proposta de Lina Bo Bardi, evidenciando a validade de uma retomada do projeto original desse museu como forma de recuperar um espaço de vivência cultural fundamental da cidade de São Paulo - que, como poucos, nasceu de um profundo entendimento das especificidades da cultura brasileira.

Palavas-chave: museografia; museus de arte; design; instituições culturais; curadoria; identidade cultural; Bardi, Lina Bo. 


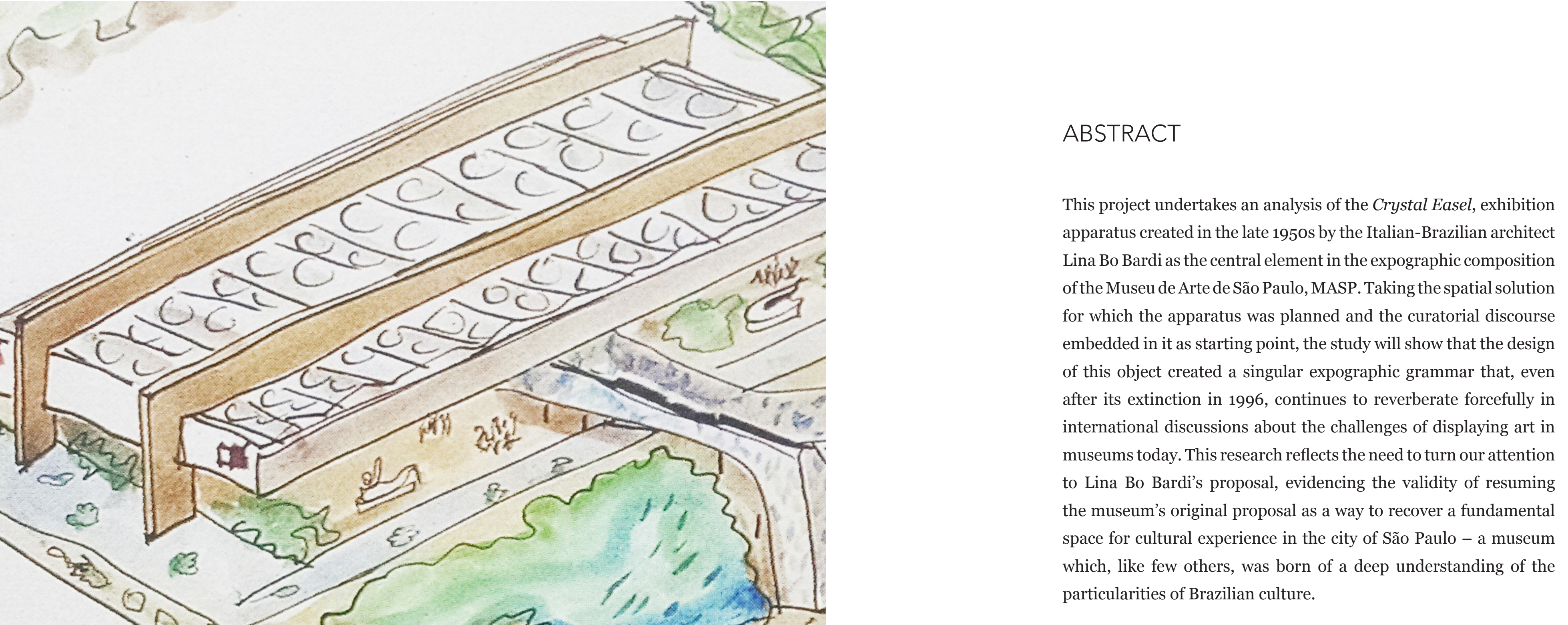
of the Museu de Arte de São Paulo, MASP. Taking the spatial solution which the apparatus was planned and the curatorial discourse in study will show that the desig international discussions about the challenges of displaying art in museums today. This research reflects the need to turn our attention Bo Bardi's proposal, evidencing the validity of resuming particularities of Brazilian culture.

Keywords: museography; art museums; design; cultural institutions; curatorship; cultural identity; Bardi, Lina Bo. 
1. DA ITÁLIA PARA O BRASIL -

A BAGAGEM DE LINA BO BARDI

1.1. A Guerra como escola:

contextualização histórica

1.2. Allestimento Archittetonico:

o princípio do design de exposições

2. AS ORIGENS DO MASP - CHATÔ E A "MAIOR GALERIA DE ARTE DO MUNDO"

2.1. Definições da vocação do museu:

a primeira sede do MASP

2.2 Residência definitiva / projeto definidor:

MASP na Avenida Paulista

3. UMA NOVA FORMA

DE SE RELACIONAR COM ARTE

3.1 O cubo branco e a pretensa

neutralidade dos espaços expositivos

3.2 O Cavalete de Cristal: design de uma

nova forma de ver e entender arte

3.3 Frente e verso: proposta curatorial

transformada em display

3.4 Um museu que passa a negar a si mesmo:

a supressão da transparência

4. O USO CONTEMPORÂNEO

\section{DO CAVALETE DE CRISTAL}

4.1 Levantamento de projetos atuais que revisitam o display

4.2 Deslocamentos do cavalete:

o que fica pelo caminho

5. O RETORNO DOS CAVALETES: UM FUTURO QUE DEPENDE DO PASSADO 
manda daqueles que foram privados de vivenciar uma experiência única. Felizmente, ao final de 2014, para surpresa de todos, pouco antes do fechamento desta dissertação, o MASP anunciou grande reformulação de sua equipe, o que incluiu a entrada do empresário e ex-presidente da Fundação Bienal, Heitor Martins, como presidente, e a vinda de Adriano Pedrosa, que assumiu o cargo de diretor artístico. Em sua primeira declaração pública, Pedrosa sinalizou que a proposta para esse novo momento é fazer com que o MASP recupere sua vocação original e que os cavaletes voltem a ocupar a pinacoteca.

O projeto de pesquisa inicialmente apresentado para este mestrado era intitulado "Design de exposição como plataforma discursiva: negociações entre curadores e designers", e propunha uma discussão acerca de questões ligadas ao design de exposições de arte a partir não de um viés especificamente formal ou estético, mas, sim, buscando entender a maneira como essas soluções visuais surgem e se articulam em relação às propostas curatoriais a que elas estão vinculadas. O objetivo era discutir um histórico descompasso entre design e curadoria - que, muitas vezes, acabam sendo trabalhados de maneira isolada, sem uma preocupação concreta em buscar uma construção de linguagem e objetivos comuns -, e apontar para o começo de uma percepção mais afinada, por parte de ambos os circuitos, de que não há mais sentido em se pensar numa solução visual para uma exposição que não esteja integrada ao seu próprio discurso.

As reflexões passavam por exposições como a $24^{\mathrm{a}}$ Bienal de Arte de São Paulo, ocorrida no ano de 1998, que teve como curadores Adriano Pedrosa e Paulo Herkenhoff, projeto museográfico de Paulo Mendes da Rocha e comunicação visual de Raul Loureiro e Rodrigo Cerviño Lopez. Escolhemos essa Bienal por ela representar um divisor de águas dentro das histórias das bienais de São Paulo: propôs uma grande mudança na organização interna da curadoria, buscando um partido menos eurocentrista - padrão da maioria das bienais do mundo até aquele momento. Trouxe, também, para o centro da discussão o conceito de Antropofagia, do escritor paulista Oswald de Andrade, como recurso para tratar a exposição a partir de questões legitimamente brasileiras, de uma maneira mais flexível e aberta - e menos historicista, e isso precisava ser traduzido no projeto expográfico. À medida que o estudo foi se desenvolvendo, percebeu-se a necessidade de se promover um afunilamento do tema para dar conta de sua complexidade. Estava claro que o interesse principal era a relação do design dos diplays - aparatos nos quais as obras são apoiadas, assentadas ou penduradas - com o pensamento curatorial, e a importância de haver um alinhamento entre essas partes. Assim, entre muitas exposições e museus estudados, chegou-se à conclusão que o cavalete de cristal sintetiza o desejo do estudo de maneira precisa: é uma peça desenhada para dispor obras e que articula, com limpidez, um partido curatorial a partir de sua própria configuração. Além disso, o cavalete reverbera de forma vibrante, ainda hoje, como raro exemplo de uma expografia pensada com mais liberdade e consciente de seu espaço de atuação. 


\section{DA ITÁLIA PARA O BRASIL - \\ A BAGAGEM DE LINA BO BARDI}

1.1. A Guerra como escola: contextualização histórica

Lina Bo Bardi ocupa um lugar único na história da arquitetura brasileira e seu trabalho é, cada vez mais, debatido nacional e internacionalmente. Para entendermos as razões que levaram à singularidade e potência de sua obra e pensamento, é importante conhecermos sua origem e percurso, além do significativo contexto histórico do qual ela faz parte. Sua arquitetura atemporal parte de um momento histórico de profunda transformação da arquitetura do próprio ocidente.

Achillina Bo nasceu em Roma, Itália, em 1914 - ano em que teve início a Primeira Guerra Mundial, que modificou enormemente a geografia da Europa, decretando o fim de quatro impérios e levando muitos países a severas crises econômicas e sociais. Lina cresce num cenário de incertezas políticas e econômicas, em uma Itália que tenta encontrar maneiras de se reerguer e que acaba por ser transformada em uma ditadura fascista em 1935

Após estudar Desenho no Liceu Artístico, Lina Bo recebe, em 1940, durante a Segunda Guerra Mundial, seu diploma de graduação pela Faculdade de Arquitetura de Roma. Era uma escola tradicionalista, com claras orientações fascistas - linha dominante nessa cidade - e que não condizia com o pensamento da arquiteta. Por essas razões, muda-se para Milão, onde passa a trabalhar com Gio Ponti, arquiteto que liderava um movimento pela valorização do artesanatoitaliano, além de ser diretor da importante revista Domus. 
O trabalho no escritório de Gio Ponti introduz Lina num ambiente intelectual e artístico de vanguarda, em meio ao movimento racionalista da arquitetura, ao nascimento do cinema neorrealista, à literatura de resistência, aos artistas surrealistas, aos dadaístas... Além de Ponti, ela convive com Pagano, De Chirico, Elio Vitorini, Bruno Zevi e Roberto Rosselini, entre outros. Torna-se, assim, filha legítima das vanguardas históricas europeias, que tinham em seu ideário a ruptura como palavra de ordem. Ruptura com os valores do passado, com as tradições, com a própria história, numa incansável busca do novo. Em várias ocasiões, até sua morte, em 1992, Lina dirá que "a verdadeira vanguarda do início do século 20, aquela russa, francesa, [...] internacional, não havia ainda perdido a metáfora. ${ }^{1}$

Um dos reflexos da crise do pós-guerra foi o pouco espaço que os arquitetos tiveram para exercer sua profissão. Na impossibilidade de atuar como arquiteta, Lina começa a se dedicar a atividades alternativas. Desenvolve ilustrações para diversas publicações, escreve matérias que ensinavam a transformar embalagens descartáveis em objetos de uso cotidiano e discute a otimização e funcionalidade dos espaços habitacionais. Sua relação pessoal com a ideia de artesanato tem origem nesse momento. A vivência de todas essas situações de carência iriam reverberar no que que ela encontraria no nordeste do Brasil anos depois.

Em tempo de guerra, uma ano corresponde a 50 anos, e o julgamento dos homens é um julgamento de pósteros. Entre bombas e metralhadoras, fiz um ponto da situação: importante era sobreviver, de preferência incólume, mas como? Senti que o único caminho era o da objetividade e da racionalidade, um caminho terrivelmente dificil quando a maioria opta pelo "desencanto" literário e nostálgico. Senti que o mundo podia ser salvo, mudado para melhor, e que esta era a única tarefa digna de ser vivida, o ponto de partida para poder sobreviver. ${ }^{2}$

FERRAZ, M. Lina Bo Bardi e a Tropicália. Projeto Design. 337 ed.. 2008 2 BARDI, Lina Bo. Curriculum literário. In: BO BARDI, Lina. Lina Bo Bardi. São Paulo: Instituto
Lina Bo e P. M. Bardi, 1993.
Lina se envolveu cada vez mais com a reflexão e produção de textos que discutiam a especificidade daquele momento histórico, oferecendo uma visão crítica sobre o comportamento da sociedade, assim como sobre o que deveria mudar a partir do ainda fresco ideário moderno.

Em pouco tempo ela própria passa a dirigir a revista e a atuar politicamente, integrando a resistência à ocupação alemã durante a Segunda Guerra Mundial (1939-1945) e colaborando com o Partido Comunista Italiano (PCI), então clandestino. ${ }^{3}$

Ainda em Milão, fundou, em parceria com o crítico Bruno Zevi, a revista A-Cultura della Vita e escreveu artigos que se tornariam referência em defesa de uma visão contemporânea sobre a forma de habitar as cidades.

Havia, na Itália da época, uma procura pela simplicidade em estudos sobre a arquitetura "espontânea", uma busca do abrigo universal, indicada muitas vezes na arquitetura feita pelo homem simples, do campo, como produto 'natural' ao longo dos tempos. O país manifestava com vigor essa característica modernista de construir um modelo que unisse tradição histórica e identidade nacional. ${ }^{\star}$

Nesse momento pós-guerra, os museus começam a ganhar um novo papel dentro da necessária renovação das cidades. O desejo é o de desenvolver museus coerentes com seu tempo e lugar, e capazes de gerar movimento e interesse por parte da população, numa tentativa de restabelecer a autoestima coletiva. Em 1946, Lina Bo casa-se com Pietro Maria Bardi, um crítico e historiador da arte e arquitetura moderna na Itália. Juntos, no ano seguinte, decidem viajar para o Brasil. Lina se naturaliza brasileira, sua "pátria de escolha” ${ }^{5}$, em 1951.

http://enciclopedia.itaucultural.org.br/pessoa1646/lina-bo-bard

LATORRACA, G. Maneiras de Expor. http://www.vitruvius.com.br/revistas/read/arquitextos/15.173/5335

5 "Quando a gente nasce, não escolhe nada, nasce por acaso. Eu não nasci aqui, escolhi esse lugar para viver. Por isso, o Brasil é meu país duas vezes, é minha 'Pátria de Escolha', e eu me

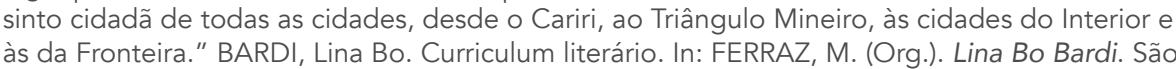
Paulo: Instituto Lina Bo P. M. Bardi, 1993. p. 12. 
Juntos, eles formavam um casal arrojado e que costumava não dar atenção a qualquer tipo de barreira conservadora. Ao desembarcar no Brasil, vindos de uma Europa abatida, deparam-se com um país em transformação e se abrindo a inovações. Era um novo período que o Brasil vivia, com uma crescente e influente classe de intelectuais e um movimento de abertura política. Àquela época, a arquiteta declara que "aqui estavam as condições ideais para se construir um país moderno” (FERRAZ, 1993, p. 35).

Chegada ao Rio de Janeiro de navio, em outubro. Deslumbre. Para quem chegava pelo mar, o Ministério da Educação e Saúde avançava como um grande navio branco e azul contra o céu. Primeira mensagem de paz após o dilúvio da 2a Guerra Mundial. Me sent num país inimaginável, onde tudo era possível. Me senti feliz, e no Rio não tinha ruínas. ${ }^{6}$

Um ano após se estabelecer, a convite do empresário paraibano, Francisco Assis Chateaubriand - a quem conheceu no período em que morava no Rio de Janeiro -, o casal se engaja na idealização do Museu de Arte Moderna de São Paulo, o MASP. As atividades se iniciaram em 1947, num edifício localizado à Rua Sete de Abril no centro da cidade, e que mais tarde se mudaria para o atual edifício, situado à avenida Paulista. Pietro foi convocado para ajudar a compor e definir os rumos da então incipiente coleção de Chateaubriand, coleção esta que deve sua viabilização ao momento econômico prolífico que São Paulo vivenciava, no auge da cultura cafeeira e, simultaneamente, à profunda crise enfrentada pela Europa pósguerra - que fez com que colecionadores e galeristas se desfizessem de obras de peso a preços muito abaixo do mercado. Lina Bo Bardi ficou incumbida por Chateaubriand de criar as condições ideais de fruição da coleção no espaço.

Desde o início da idealização do MASP, o casal viu nesse trabalho a oportunidade para desenvolver um modelo de museu que levasse em conta a função social e educativa que esse tipo de instituição deveria exercer, além de aproveitar o fato de que não havia no Brasil, até aquele momento, nenhuma coleção capaz de sintetizar as linhas mestras da história da arte como aquela que começava a se delinear.

Entre os anos 1950 e 1965, Lina foi responsável pela edição da revista Habitat, que teve nomes importantes em sua direção, além dela própria: Flávio Motta, Pietro Maria Bardi e Geraldo N. Serra. Nessa publicação, dava-se destaque para temas como arte popular, arquitetura, inovações, teatro, música e cinema. Além disso, apresentava sempre ensaios que propunham um ilhar mais aprofundado sobre a cultura brasileira, ressaltando a importância de não criar uma separação entre antigo e moderno, e incentivando um olhar mais amplo da história. No primeiro número da revista, Lina publica o artigo "Função social dos Museus". "Nele, afirma os mesmos pressupostos do living museum atuando para 'formar uma mentalidade para a compreensão da arte', contra as atividades de um 'mausoléu inteltectual', preocupado apenas com a conservação do acervo.”

Em 1958, Lina foi convidada pelo então governador Juracy Magalhães para lecionar na Faculdade de Arquitetura da Bahia e lá permaneceu por cinco anos. Durante esse período, assumiu a direção do Museu de Arte Moderna da Bahia, o MAMBA, em Salvador, e restaurou o Solar do Unhão - um edifício histórico datado de 1690 que se tornaria, através de seu projeto, um museu dedicado exclusivamente à arte popular. Lina promoveu experiências museográficas importantes nesse espaço, que serviriam de base para o desenvolvimento da solução de display $^{8}$ e expografia para o MASP.

Foi durante esse período no nordeste do país que Lina aprofundou seu grande interesse pelas manifestações de arte popular e artesa-

MIYOSHI, Alex. Arquitetura em Suspensão - O Edifício do Museu de Arte de São Paulo. São Paulo: Armazém do lpê, 2011.

A palavra diss á é um termo amplamente usado em discussões sobre museografia e será utilizada nessa dissertação para designar um "aparato expositivo", ou seja, a maneira como uma
obra é inserida no espaço da exposição. 
nato. Passou a trabalhar em prol de um novo conceito de construção de identidade cultural, que deveria levar em conta as especificidades regionais. A vivência em Salvador modificou de maneira definitiva seu processo de pensamento e projeto no âmbito da arquitetura e expografia. Foi um momento divisor de águas:

[...] Ela, que já havia se naturalizado brasileira em 1951, torna-se agora brasileiríssima de alma. Foi pioneira ao mergulhar fundo na produção popular dos objetos do dia a dia. Redescobre o Brasil para os brasileiros, ao resgatar e trazer a público a produção artesanal, ou pré-artesanal, como fazia questão de diferenciar. Lina via nisso uma condição excepcionalmente favorável ao desenvolvimento de um design autóctone, original, moldado na medida do homem brasileiro para atender suas necessidades. ${ }^{9}$

No final da década de 1970, a arquiteta é convidada para projetar uma de suas obras mais paradigmáticas: o SESC Pompeia. O terreno de $16.000 \mathrm{~m}^{2}$ ocupado por uma fábrica abandonada de tambores de metal construída no final da década de 1930 foi convertido com êxito num pulsante e democrático centro de lazer e cultura - sem perder a aspereza de seu caráter industrial original. É hoje, ainda, um marco que impressiona quem visita o lugar pela primeira vez: um espaço de comunhão, que abraça todos os perfis sociais, e que é generoso de maneira a reunir todos em atividades gregárias. Representa um marco inaugural num momento em que novas teorias sobre lazer estavam sendo desenvolvidas, em especial pelo sociólogo francês Joffre Dumazedier.

O objetivo não é o de uma mundana "inclusividade", mas um confronto entre eventos de matriz e carga expressiva heterogêneos. Apesar dos pressupostos ideológicos de uma estética de choque, emerge "um equilíbrio quase perfeito". ${ }^{10}$

9 FERRAZ, M. A Poesia Vital de Lina Bo Bardi. Folha de S. Paulo, São Paulo, 8 dez. 1996.

10 ZEVI, B. A Fábrica dos Signos. In Cidadela da Liberdade - Lina Bo Bardi e o SESC Pompeia
O projeto se tornou uma importante referência para a história da arquitetura na segunda metade do século XX.

Lina manteve intensa produção cultural até o fim da vida, em 1992, em São Paulo. O seu legado tem sido, cada vez mais, reconhecido e a efeméride de seus cem anos, em 2014, propiciaram uma maior exposição de sua experiência profissional e humana.

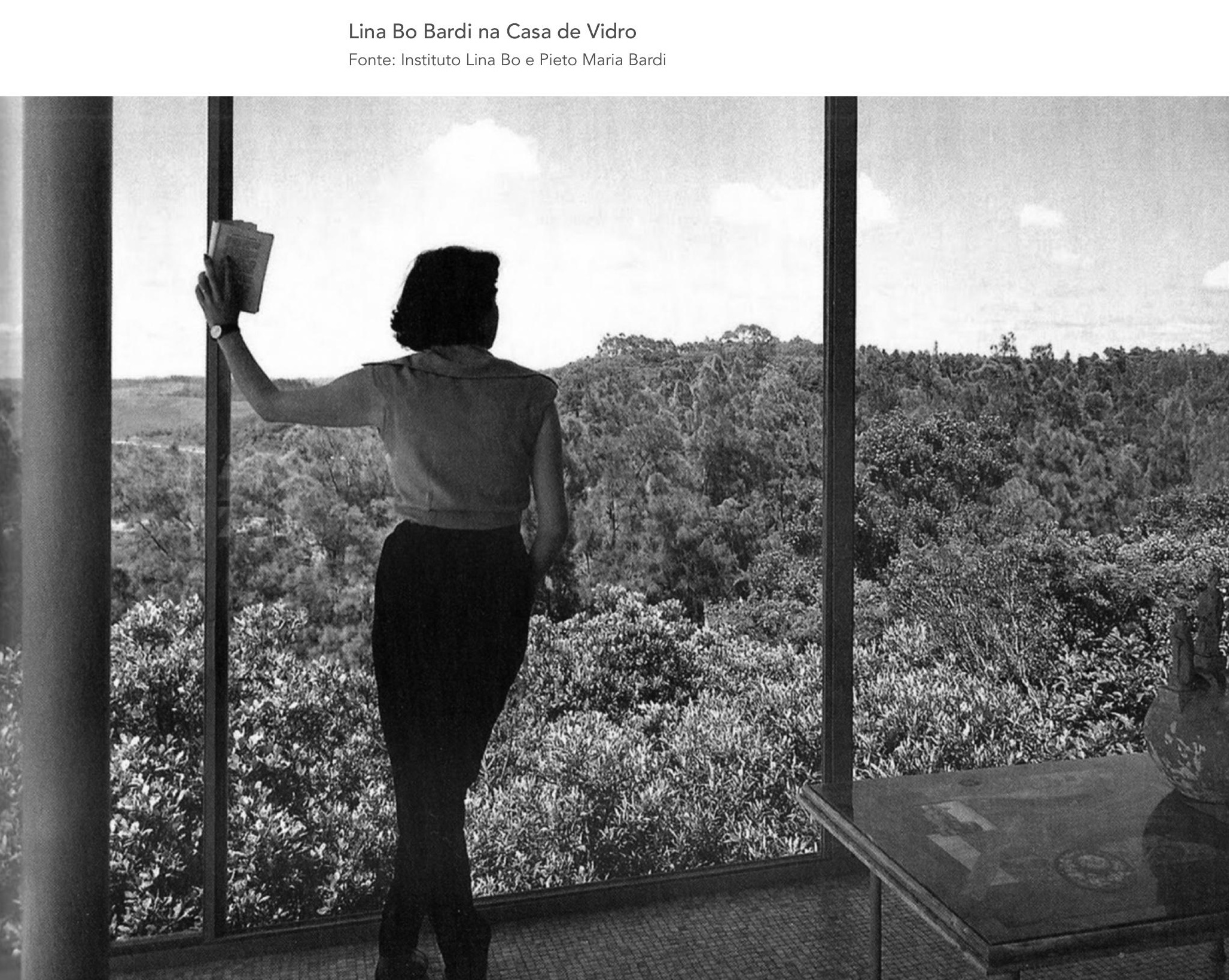


sições deveriam embutir em seu escopo frente ao contexto pós-guerra - se transformou em uma excelente oportunidade de propor e experimentar novas maneiras de vivenciar esses espaços a partir dos preceitos modernos, encarando os edifícios não só como um patrimônio, mas também como um espaço de criação onde o novo poderia se fazer presente. E é dessa forma que nasce o allestimento arquittonico.

Na Itália, reformar e adaptar edificios para o uso de museus foi uma solução constante em quase todo o século XX. Os fatores particulares da arte, das coleç̃es e do patrimônio italianos conduziram ao desenvolvimento de uma arquitetura interna, atenta às particularidades das obras de arte e edificios históricos. Embora tal prática de adaptação de prédios ao uso museal não tenha se restringido à Itália (ocorreu também com o MoMA de Nova Iorque e com o primeiro MASP, da rua 7 de abril, entre outros), foi lá que o "museu interno" obteve resultados extremamente diversificados e surpreendentes. ${ }^{13}$

Essa nova disciplina visava a gestão e organização de exposições temporárias, eventos e exposições de museus dentro de espaços arquitetônicos já consolidados. Ela difere da arquitetura de interiores porque está relacionada com um entendimento das obras de arte que serão expostas e depende da construção de um pensamento sobre como o público irá se relacionar com esse espaço planejado para a sua fruição. O que buscava-se, em última instância, era a criação de um ambiente expositivo que favorecesse o entendimento dos ideais modernos. O allestimento tornou-se, assim, campo experimental para arquitetos e artistas italianos.

No entreguerras, a liberdade dos projetos para as mostras temporárias foi maior que a das exposições permanentes dos museus. Apesar da crescente difusão dos princípios museológicos educativos, a Itália não se abriu a eles facilmente. Assim, a exposição temporária foi o terreno fértil às experimentações expositivas. Mas as experi-

\footnotetext{
13 MIYOSHI, A. Expografias Italianas do Pós-Guerra, o Masp na Rua Sete de Abril e na Avenida camp, v. 1, 2007
}

ências só eram viáveis quando não envolviam coleções antigas de pintura e escultura: foi o que ocorreu com as propostas de Edoardo Persico e Marcello Nizzolli para a Sala da Medalha de Ouro, a de Giuseppe Pagano para a Sala de Ícaro, do escultor Marcello Mascherini, ambas em 1934 na mostra da Aeronáutica no Palazzo d’Arte em Milão, e para a mostra de Ourivesaria Antiga, de Franco Albini, em 1936, para a VI Trienalle de Milão. ${ }^{14}$

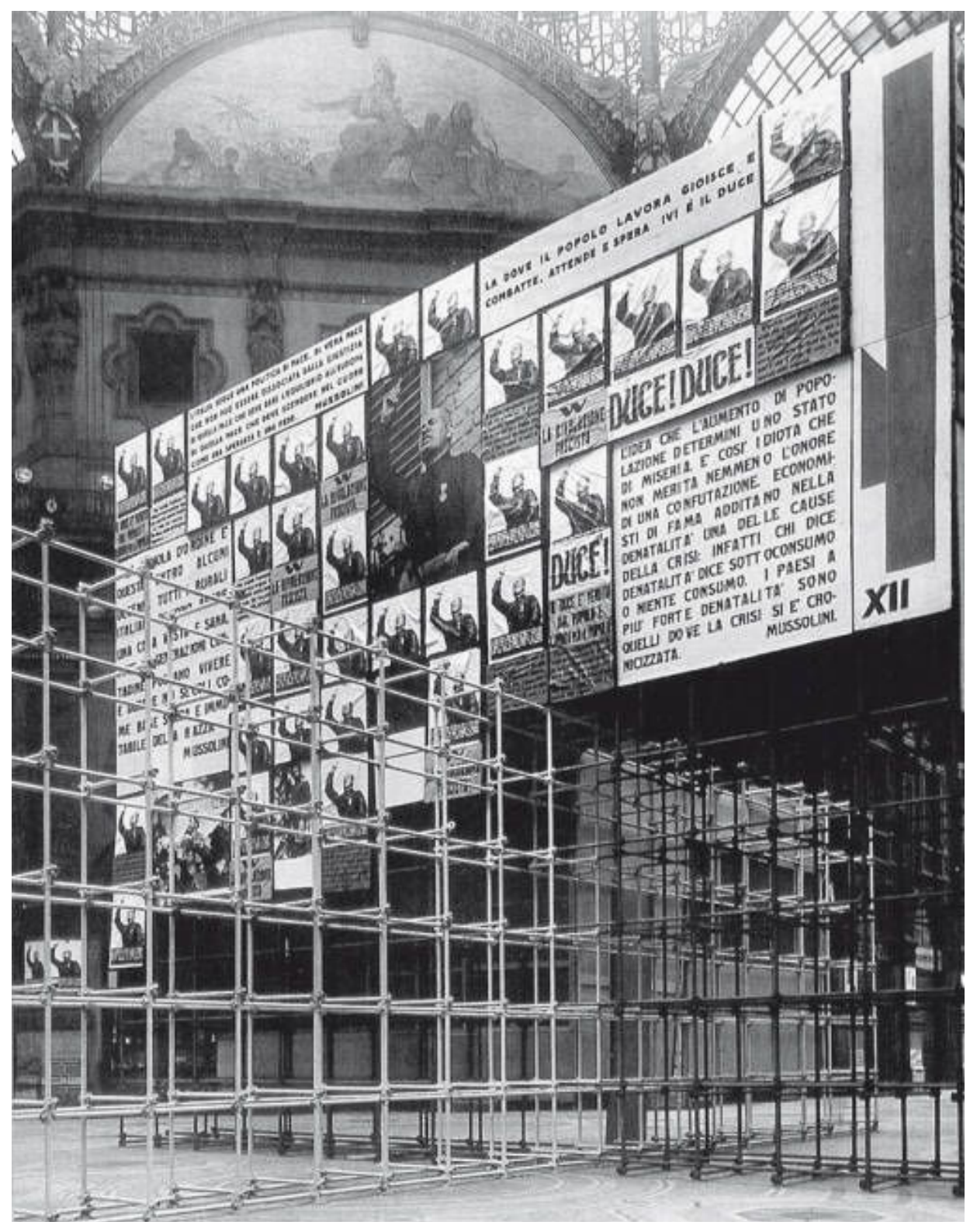

Instalação para o plebiscito de 1934 na Galleria Vittorio Emanuele II, em Milão. Eduardo Persico e Marcello Nizzoli. Fonte: http://www.ilgiornaledellarchitettura.com/articoli/2012/5/113147.html

$14 \mathrm{Id}$ 


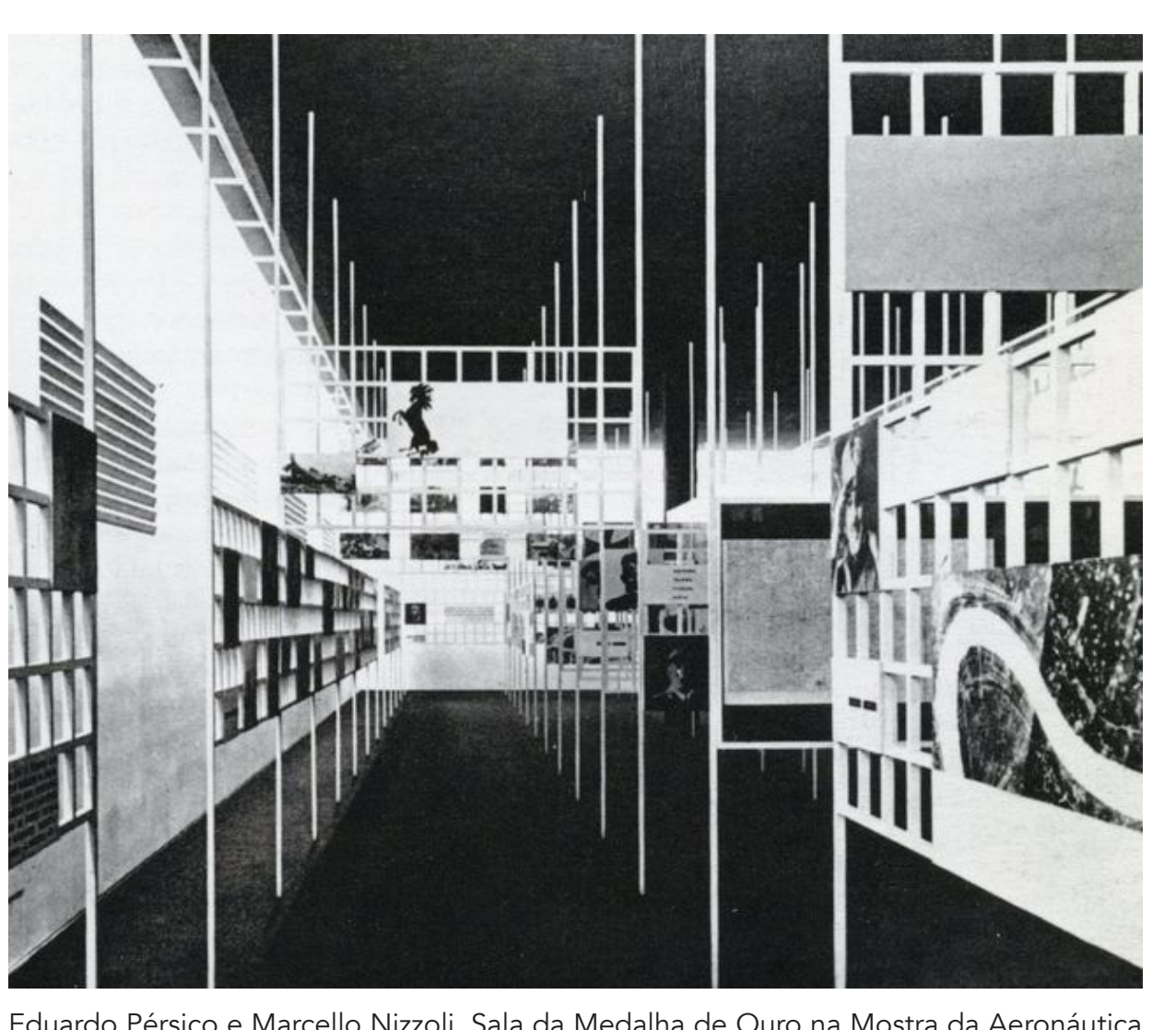

Eduardo Pérsico e Marcello Nizzoli, Sala da Medalha de Ouro na Mostra da Aeronáutica Italiana, Milão, 1934. Fonte: http://www.wall|paper.com/gallery/art/framing-modernism -london/17051075\#3552

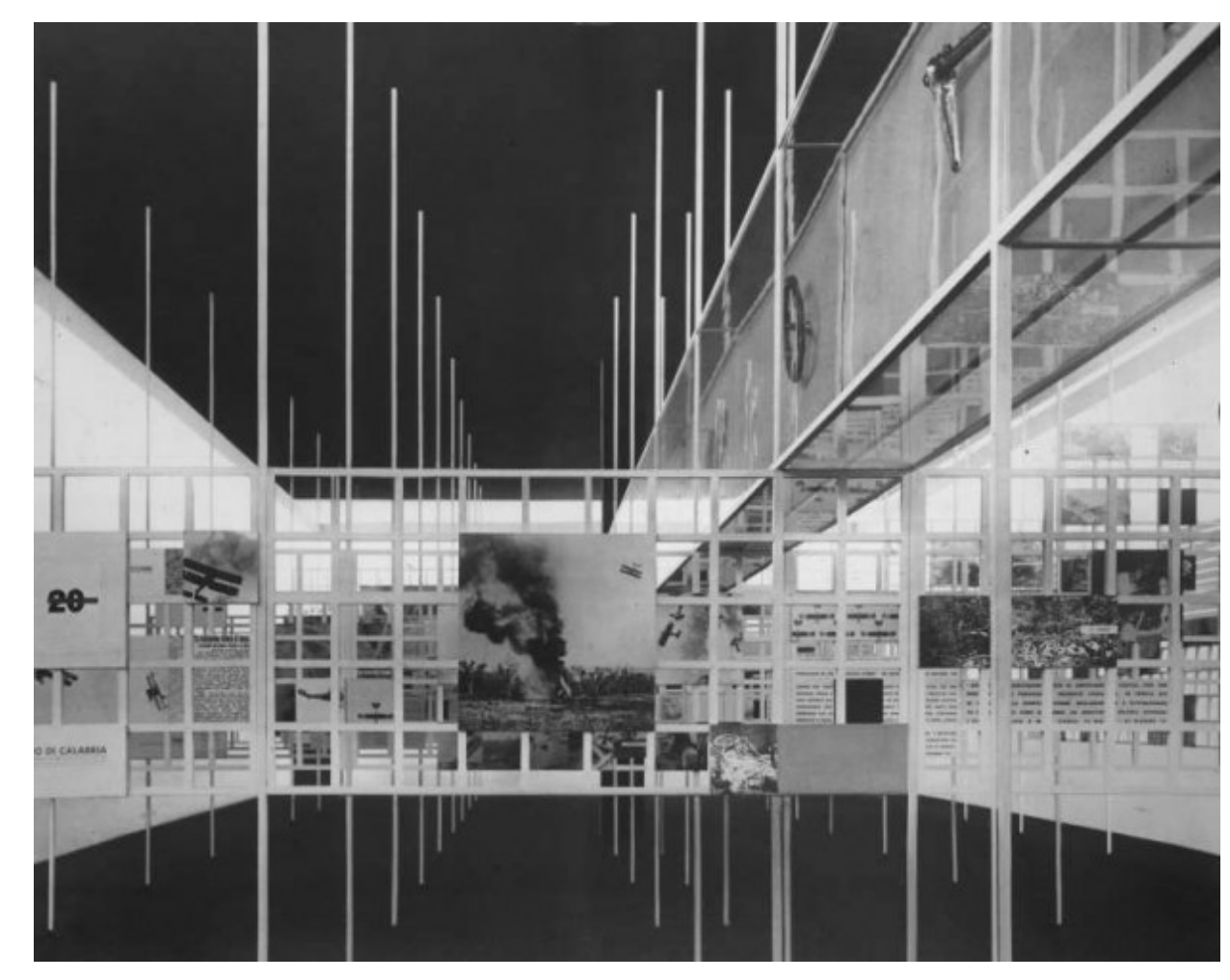

Eduardo Pérsico e Marcello Nizzoli, Sala da Medalha de Ouro na Mostra da Aeronáutica Italiana, Milão, 1934. Fonte: http://www.wallpaper.com/gallery/art/framing-modernism -london/17051075\#3552

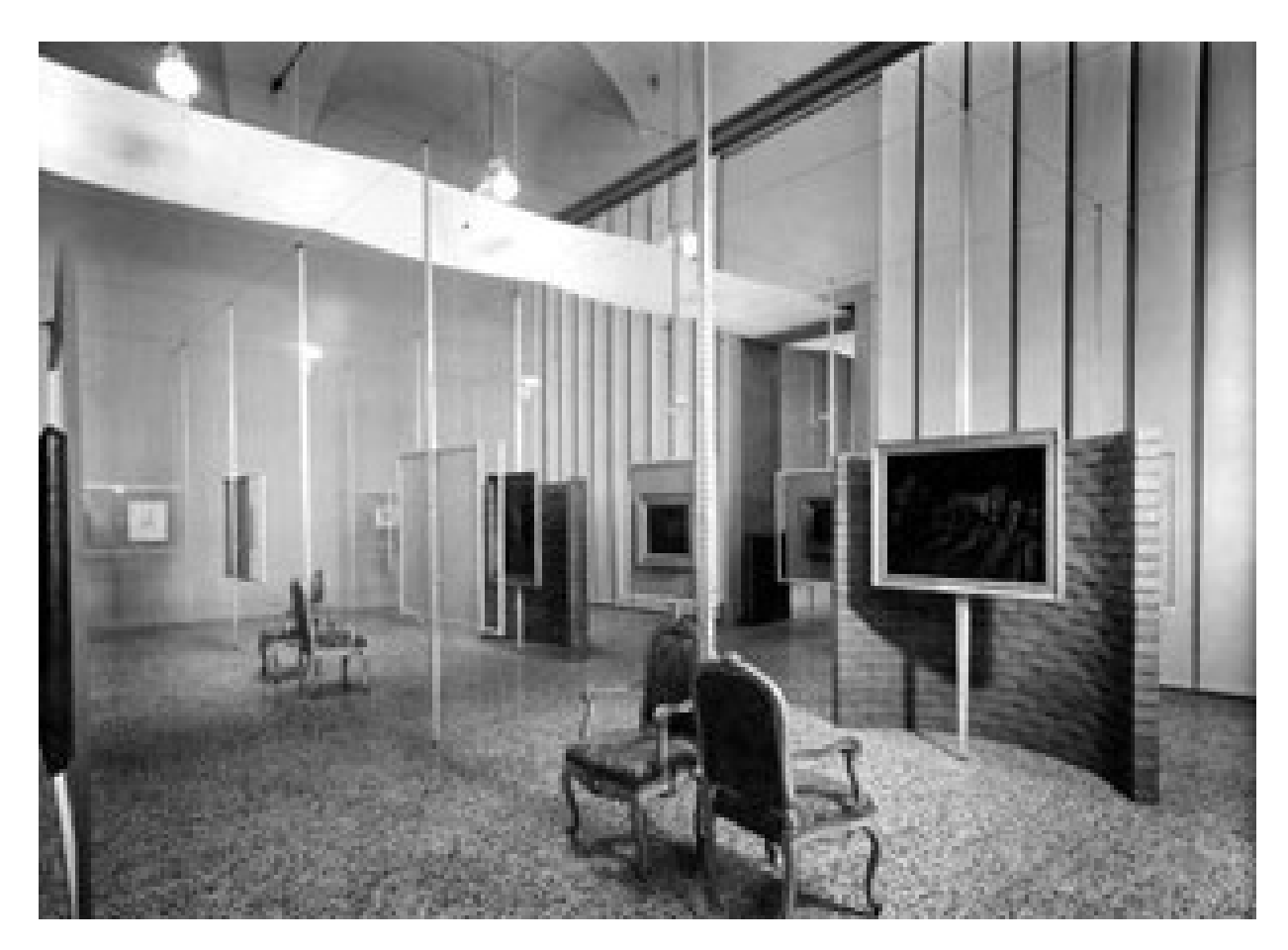

Exposição Il Scipione de Franco Albini, 1941. Fonte: Fondazione Franco Albini

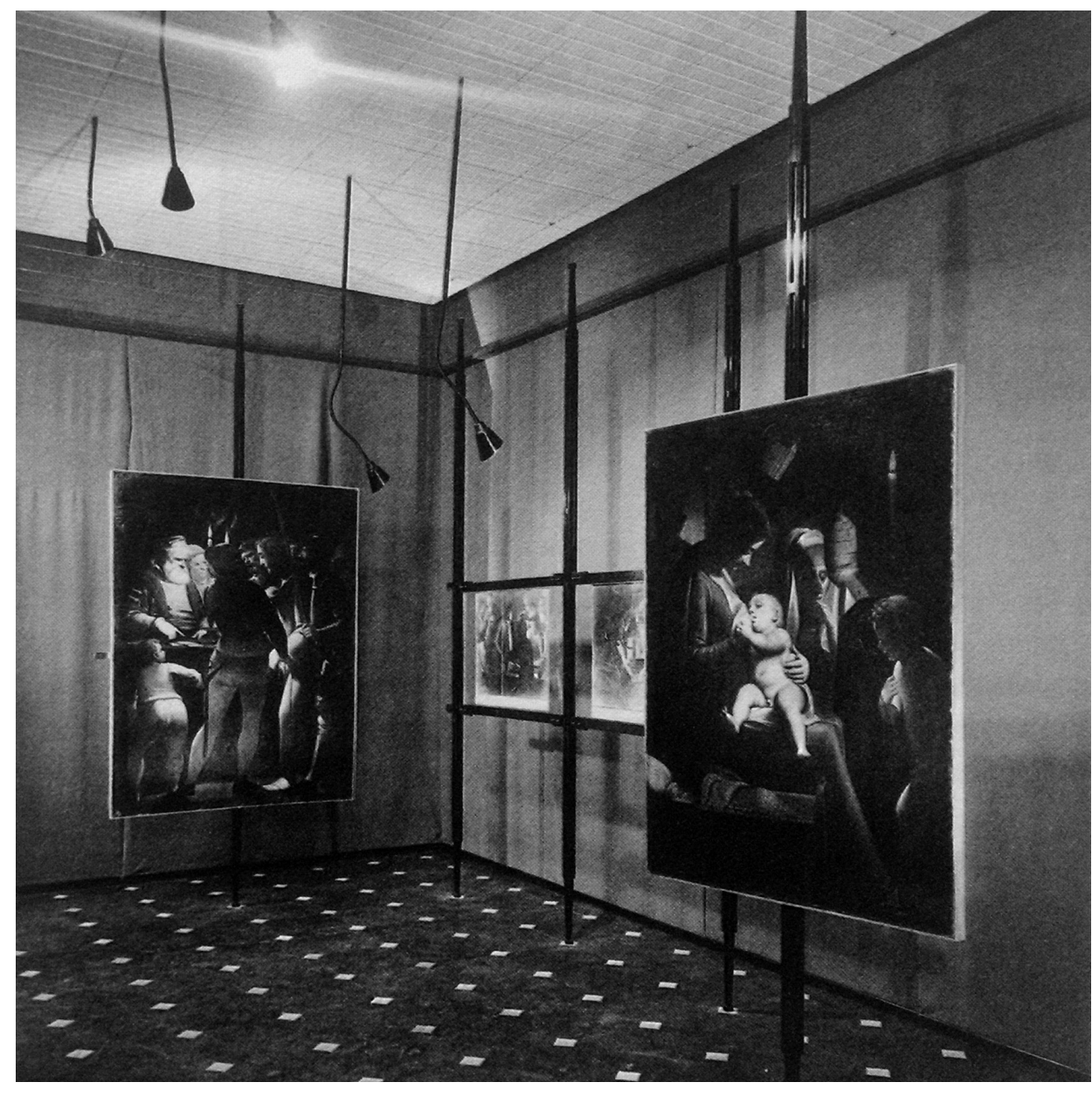

Museu do Palazzo Bianco, de Franco Albini. 1950/51. Fonte: Fondazione Franco Albini 
As exposições dos arquitetos já evidenciavam elementos que viriam a ser marcos nas museografias de Lina Bo Bardi, como tubulações aparentes, estruturas de metal sem acabamento fino, flutuação das peças no espaço e descolamento entre museografia e arquitetura. Além disso, existia um caráter educativo nessas exposições, que criavam percursos e discursos pautados pelas novas premissas da vida moderna. Era intenção dos arquitetos desse período inocular os ideais modernos na população, e os museus se tornaram bons veículos para isso. Isso também seria incorporado à bagagem que Lina levaria para o Brasil.

Com sua chegada ao território brasileiro, a arquiteta não demora a se sensibilizar pela potência, singularidade cultural e inventividade que encontra aqui, tendo especial importância o período de cinco anos em que viveu e trabalhou em Salvador, experiência essa considerada fundamental no desenvolvimento do MASP e de todos os seus projetos subsequentes. Em contato com a cultura nordestina, Bo Bardi rapidamente percebe que o pensamento moderno cultivado durante seus estudos na Itália - e voltado à ideia de uma cultura global e unificada, atenta a criar canais de comunicação com o público a fim de gerar um entendimento acerca do conceito de moderno - não faria sentido se não sofresse adaptações que permitissem o englobamento dessas especificidades culturais, atingindo e estimulando o grande público, além de criar um lugar de cultura legítima - mas, ao mesmo tempo, preparado e receptivo às grandes modernizações que ocorriam.

A arquiteta ítalo-brasileira de formação racionalista e socialista que mergulhou no universo do popular ainda na Itália, ao lado da elite arquitetônica de seu país de origem, trouxe na bagagem um olhar peculiar sobre a formação de uma cultura genuinamente moderna e amalgamada aos homens. [...] Uma postura para a formação de um gosto pelo ambiente moderno, simples, racionalizado e funcional que partisse de referências das raízes culturais e não de uma ação imposta e externa..$^{15}$
Lina percebeu na Bahia um tipo de simplicidade, que ela identificava como sendo a razão para uma maior abertura por parte da população para se relacionar com a arte. Em um documentário produzido em $1993^{16}$ sobre sua obra, a arquiteta arrisca definir essa característica como uma certa ingenuidade ou pureza, algo que já não existiria mais em São Paulo e no Rio de Janeiro, metrópoles que já haviam perdido a maior parte de seu contato com o que podemos chamar de primitivo. Ela enxergava no povo do nordeste possibilidades imensas para a população baiana por conta dessa característica.

Na linha do que Pierre Verger indica como uma capacidade do estrangeiro de perceber coisas que o povo local já não percebe mais, Caetano Veloso, no mesmo documentário, afirma que "Dona Lina - como era comumente chamada por lá - é fundadora da civilização baiana, que nós humildemente representamos, com muito orgulho." 


\section{AS ORIGENS DO MASP - CHATÔ E A "MAIOR GALERIA DE ARTE DO MUNDO"}

Ainda sem planos concretos em relação a ficar em definitivo no país, Lina e Pietro fixaram-se, primeiramente, no Rio de Janeiro ao desembarcarem no Brasil. Foi lá, durante uma exposição de arte italiana que Bardi organizou para vender algumas peças de sua própria coleção, que conheceram um personagem que definiria o rumo do casal. Assis Chateaubriand, dono de um gigantesco conglomerado de mídia, foi uma personalidade que atuou de forma marcante no campo da política e da cultura brasileira entre os anos de 1910 e 1960. Em 1946, possuía uma criteriosa coleção de arte, porém, segundo ele próprio, insuficiente até mesmo para decorar uma casa inteira. ${ }^{17}$ Neste ano, no Rio de Janeiro, conheceu o casal Bardi e não titubeou em propor para não dizer impor - que ambos se engajassem no que ele afirmava que seria "uma das maiores galerias de arte do mundo". Pietro Maria Bardi deveria ser o responsável pela tarefa de definir os rumos da coleção, pautando as novas aquisições, além de assumir a direção da galeria. Lina ficaria encarregada do projeto do espaço - que, naquele primeiro momento, seria instalado em um andar do edifício dos Diários Associados, no centro de São Paulo, do qual Chateaubriand era dono e que encontrava-se em fase final de construção. Pietro e Lina que, até então, não estavam certos se ficariam em definitivo no Brasil, decidem encarar essa empreitada. Pietro, rapidamente, deixa de utilizar o termo "galeria" e passa a empregar "museu", explicando que a separação entre arte antiga e moderna, que Chateaubriand costumava usar para definir o teor de sua futura coleção, já era ultrapassada.

Essa seria, aos olhos do casal, uma grande oportunidade de semear o olhar moderno no Brasil.

17 MORAIS, F. Chatô:o rei do Brasil. São Paulo: Companhia das Letras, 2013. 
Como já citado no capítulo anterior, o período do pós-guerra havia mergulhado grande parte da Europa em uma profunda crise. A situação só começaria a mostrar sinais de melhora após a assinatura do Plano Marshall, em julho de 1947 - um programa apoiado pelos Estados Unidos que visava a recuperação europeia, auxiliando na reconstrução dos países aliados que foram devastados pela Segunda Guerra. Assis Chateaubriand entendeu que o momento da crise era ideal para adquirir obras-primas a preços mais acessíveis. De fato, foi aproveitando esse momento de fragilidade da Europa que conseguiram obras como Retrato de Zborowski, de Modigliani, Negros Scipião, de Cézanne, Cardeal Cristóforo Madruzzo, de Ticiano, entre tantas outras. O dinheiro para as compras vinha, na maioria das vezes, diretamente de doadores da elite intelectual, cafeeira e industrial brasileira. O grande período de aquisições, que formou o corpo principal da coleção do MASP, seguiu a todo vapor até 1957.

Após as compras mais ousadas que fizemos no exterior, a situação financeira do museu, e também do País, não permitiu investimentos de maior porte e nada mais foi comprado. A coleção se enriqueceu somente com obras doadas espontaneamente por particulares, entre os quais eu me incluo. ${ }^{18}$

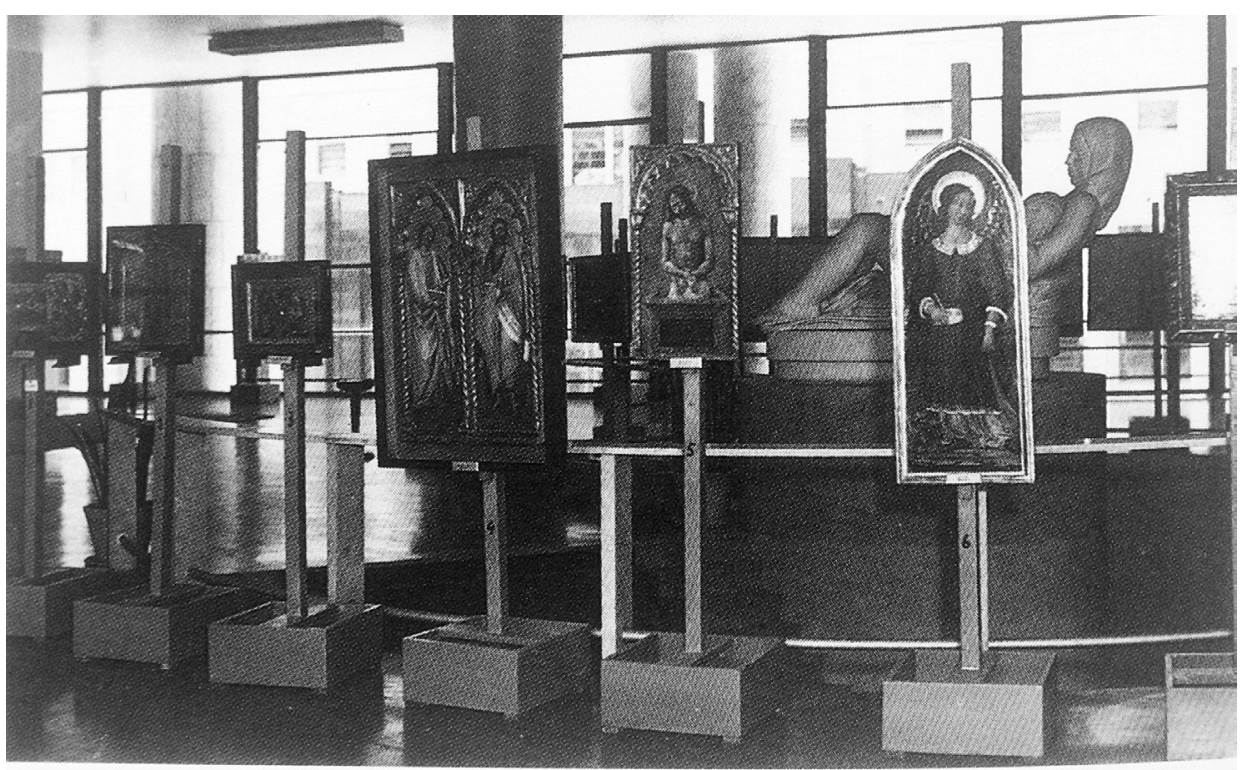

Exposição de Pintura Italiana Antiga, apresentada por Bardi no Rio de Janeiro, 1946. Fonte: BARDI, Pietro Maria. História do MASP. São Paulo: Instituto Quadrante, 1992.

18 BARDI, P. M. História do MASP. São Paulo: Instituto Quadrante, 1992

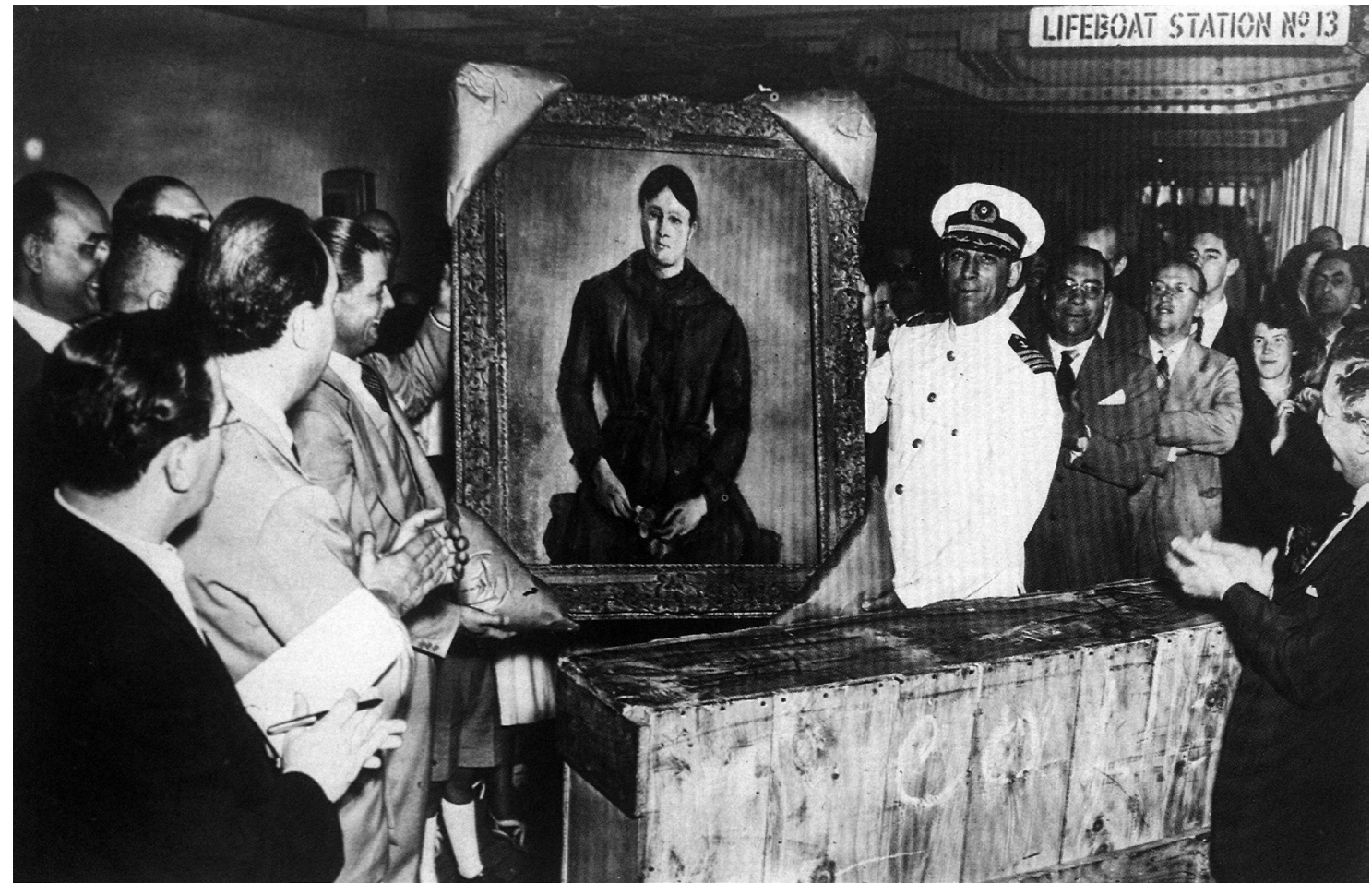

O quadro "Madame Cézanne em vermelho", de Paul Cézanne, desembarcando no Porto de Santos, em 1949. Fonte: BARDI, P. M. (1992). P. 72

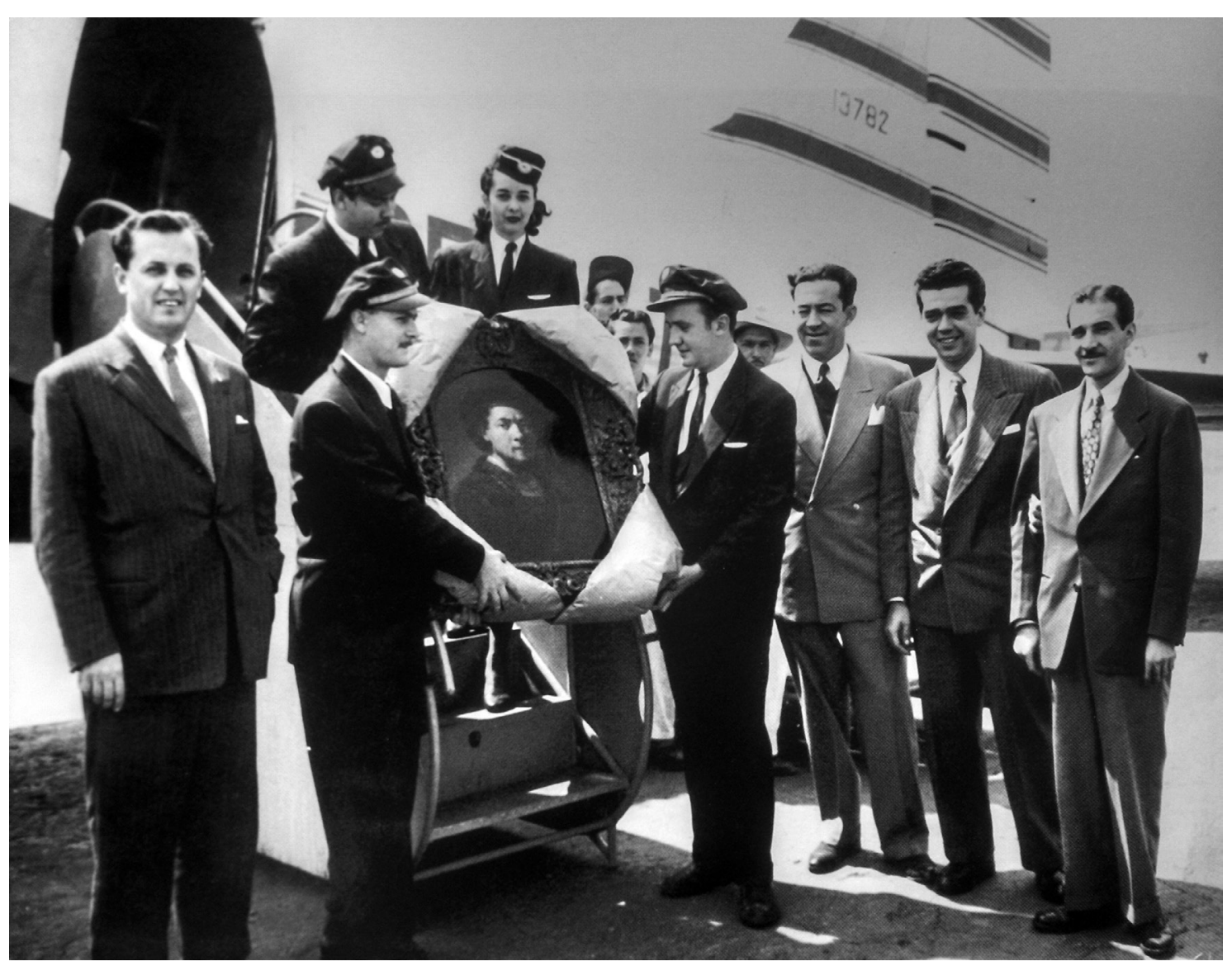

Chegada do quadro "Retrato de Jovem com Corrente de Ouro", de Rembrandt, no aeroporto de Congonhas, em 1949. Fonte: GOUVÊA, R. (2008). P. 28 
2.1 Definições da vocação do museu:

a primeira sede do MASP

A primeira sede do MASP - o prédio do Diários Associados, projetado pelo arquiteto Jaques Pilon, localizado à Rua Sete de Abril, no centro de São Paulo - não havia sido planejada para abrigar uma galeria, e muito menos um museu. Lina teria pela frente um grande desafio para adaptar aquele espaço para esse fim. Além do que, por conta do espaço exíguo e da inicial pouca quantidade de obras, a equipe julgou que seria mais adequado para aquele momento transformar o espaço não em um museu propriamente dito, mas num espaço de cultura e aprendizagem.

Naqueles anos, o museu constituiu-se em polo de um audacioso projeto cultural moderno em uma cidade ainda provinciana, mas que rapidamente se tornava o maior e mais poderoso centro industrial da América do Sul: museu de arte - o Masp -, revista de arte, arquitetura e cultura (Habitat), escola de arte e desenho industrial (Instituto de Arte Contemporânea - IAC), presença contundente na mídia (o jornal Diários Associados e a primeira televisão brasileira -TV Tupi) e projetos arquitetônicos provocadores - a começar pelo museu e pela transparência da sua própria residência no Morumbi - compunham a estratégia do casal Bardi para ultrapassar os limites conservadores da época. ${ }^{19}$

Lina providenciou adaptações na arquitetura do andar de $1000 \mathrm{~m}^{2}$ para que ele pudesse receber, além da crescente pinacoteca e das salas de exposições temporárias, auditórios e salas de aula. Lá, começou a desenvolver projetos expográficos e displays que discutiam a potencialização do caráter educativo do acervo. Os desenhos indicam, claramente, as referências da arquiteta no design de exposições italiano do entre e pós-guerra, além de carregar indícios da futura solução expográfica que seria desenvolvida para o MASP da Avenida Paulista.

19 http://www.vitruvius.com.br/revistas/read/arquitextos/10.112/22
À medida que a primeira sede do MASP foi desenvolvida dentro de um espaço não projetado para receber um museu, podemos construir um paralelo entre essa adequação e os projetos museográficos que aconteciam naquele momento na Itália - onde o que se fornecia aos arquitetos era um prédio que antes, provavelmente, se encontrava em ruínas e que, naquele momento, reformado a mando do governo, necessitava "adquirir" uma função museológica. Era uma casca sem função que, pelas mãos dos arquitetos, deveria passar a abrigar museus. Essa situação peculiar de trabalho fez com que os arquitetos italianos desenvolvessem estruturas e displays descolados física e esteticamente dos edifícios, gerando, muitas vezes, um estado de flutuação em todo o conteúdo. Era também uma forma de começar a construir uma consciência sobre os preceitos estéticos do moderno, ainda que fossem dentro de "caixas" neoclássicas. Foi de certa forma o que aconteceu no MASP da Sete de Abril - apesar de, diferente dos casos italianos, esse edifício já ter sido construído numa linguagem moderna. Tendo em mãos um andar pronto, não pensado para a função de museu, Lina criou recursos para lidar com as limitações do espaço, construindo uma linguagem visual que tinha muito a dizer. O resultado funcional e estético remete a projetos de alguns de seus conterrâneos, como podemos ver nas imagens apresentadas no capítulo anterior.

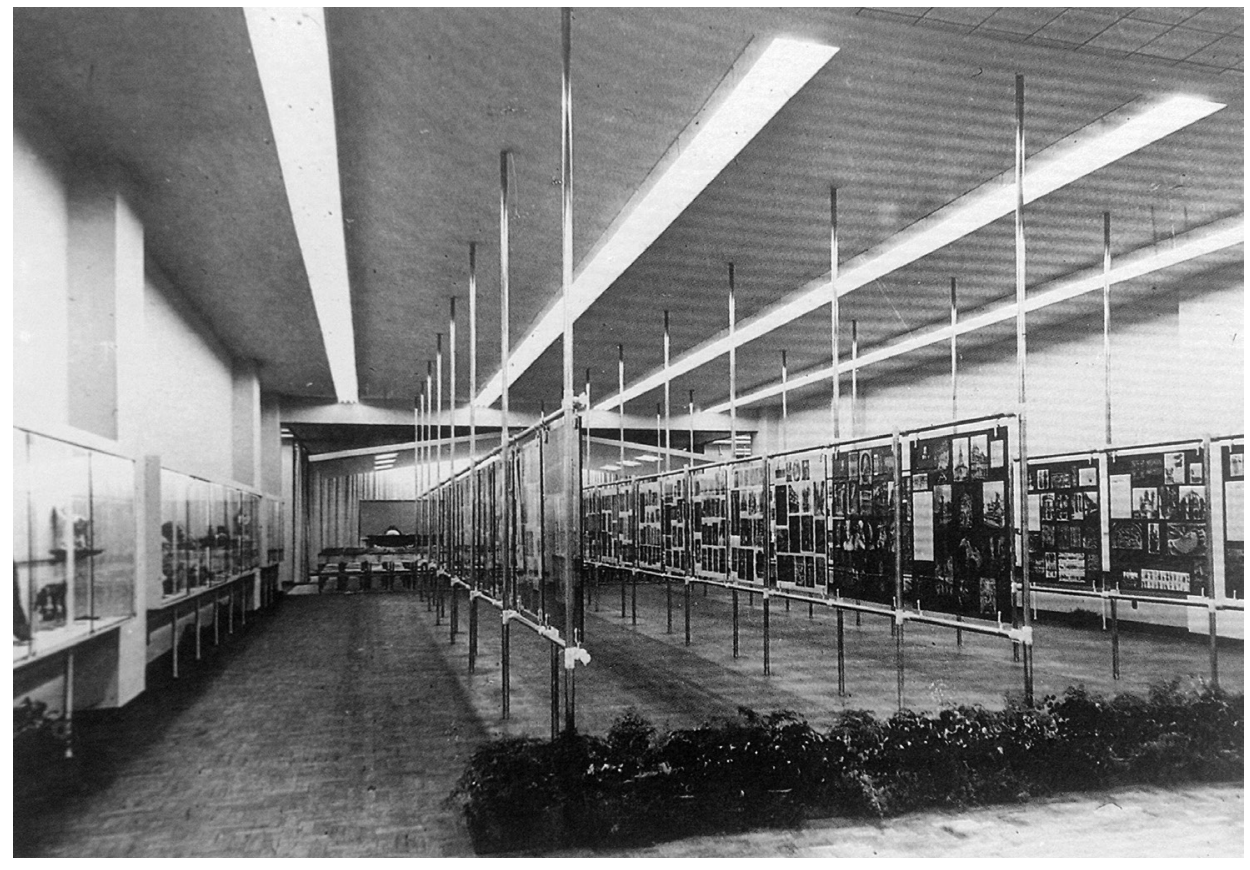

Exposição didática de História da Arte, 1947. Fonte: BARDI, P. M. (1992). P. 63. 


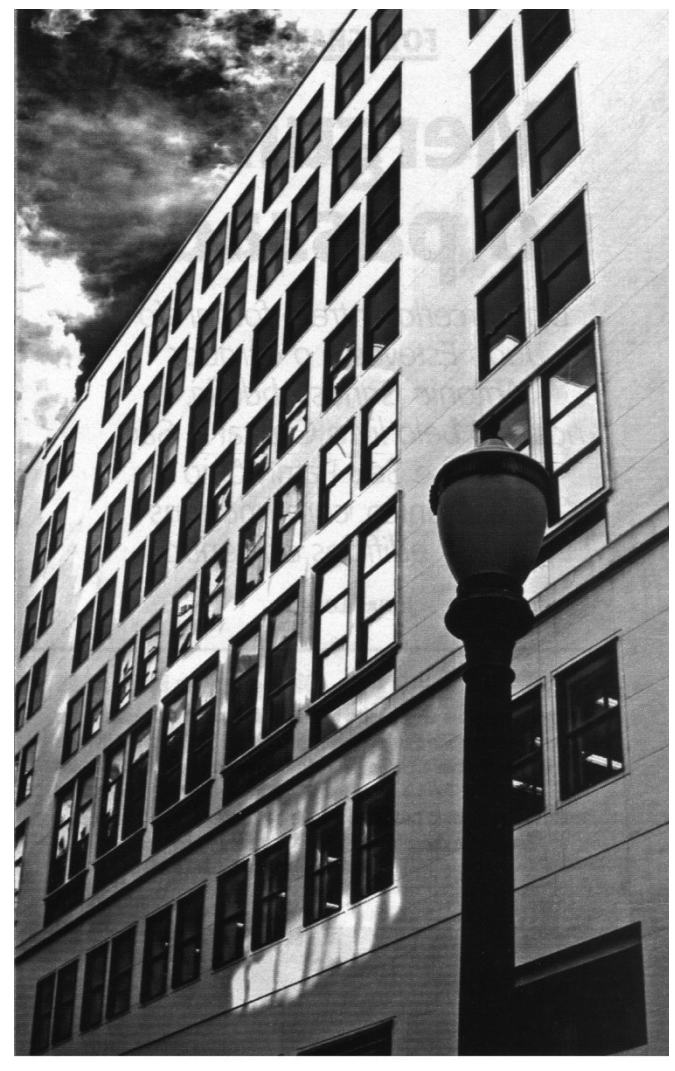

Fachada do Edifício Diários Associados, em 1948. Fonte: Veja São Paulo, Fev. 201

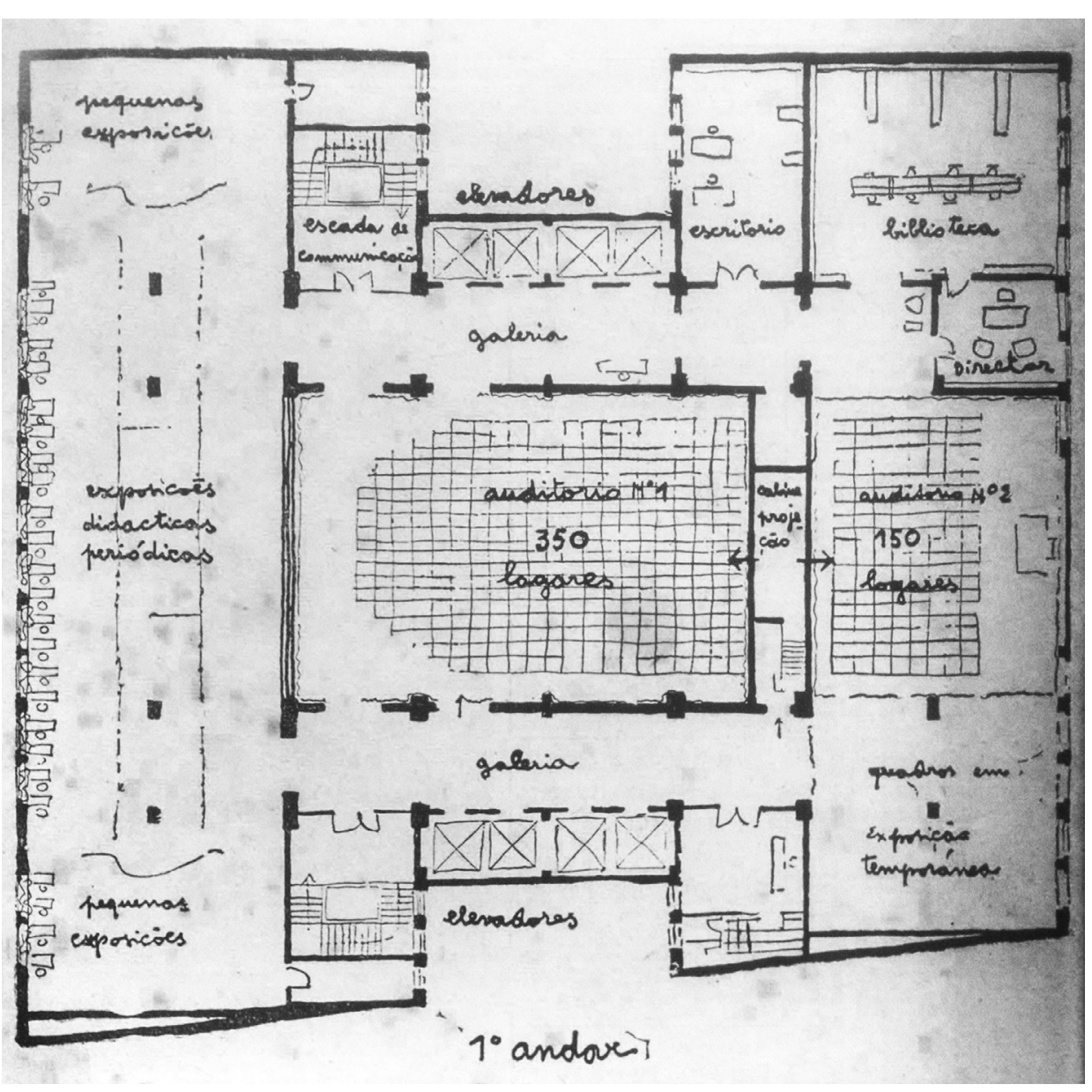

Esboço da planta de adaptação do $1^{\circ}$ andar do edifício para implantação do museu. Fonte: BARDI, P. M. (1986).P. 78

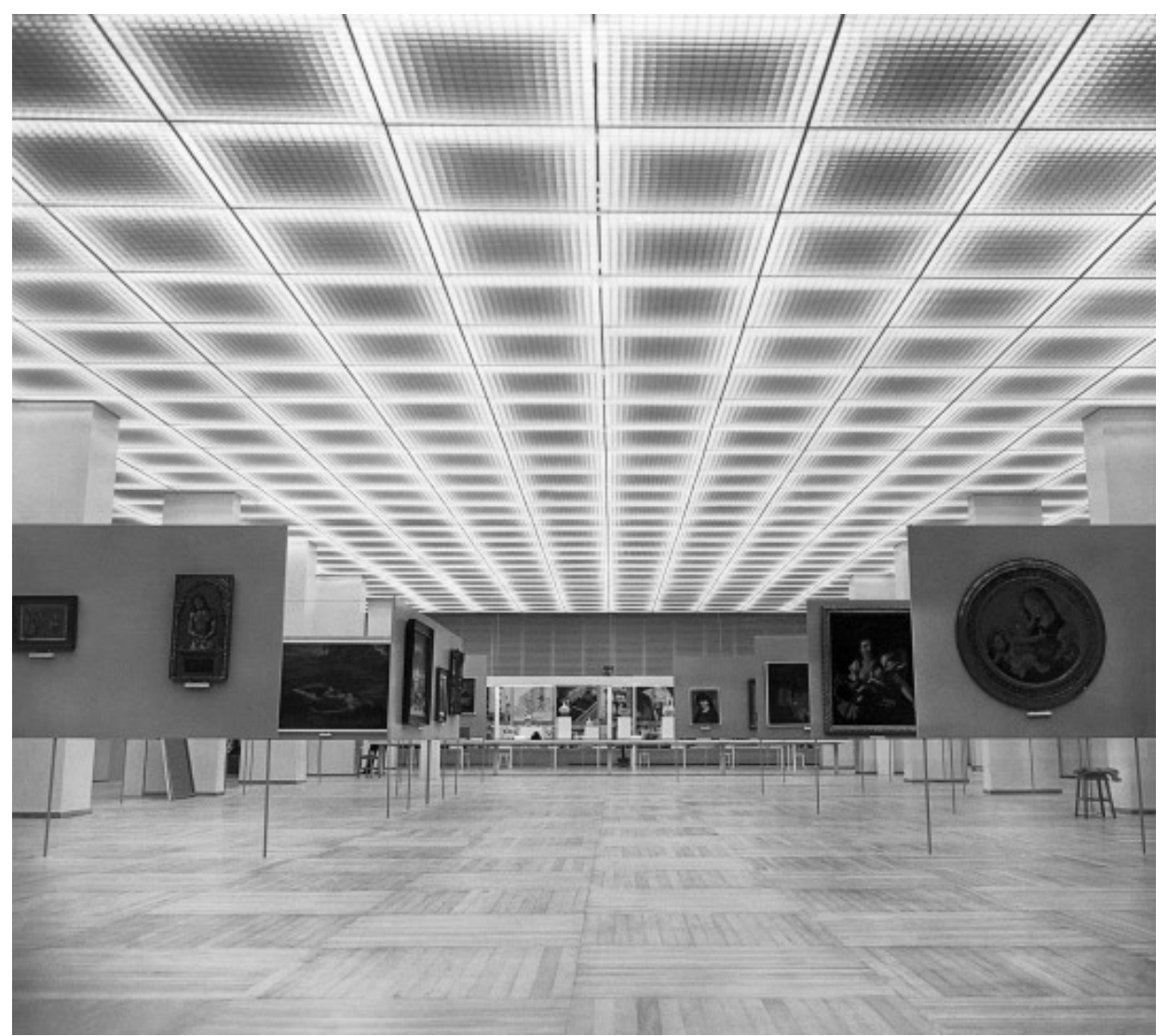

A Pinacoteca do Museu de Arte de São Paulo em 1950, logo após reforma e ampliação Foto: Coleção do Acervo Jornal Estado de Minas/O Cruzeiro/Roberto Maia

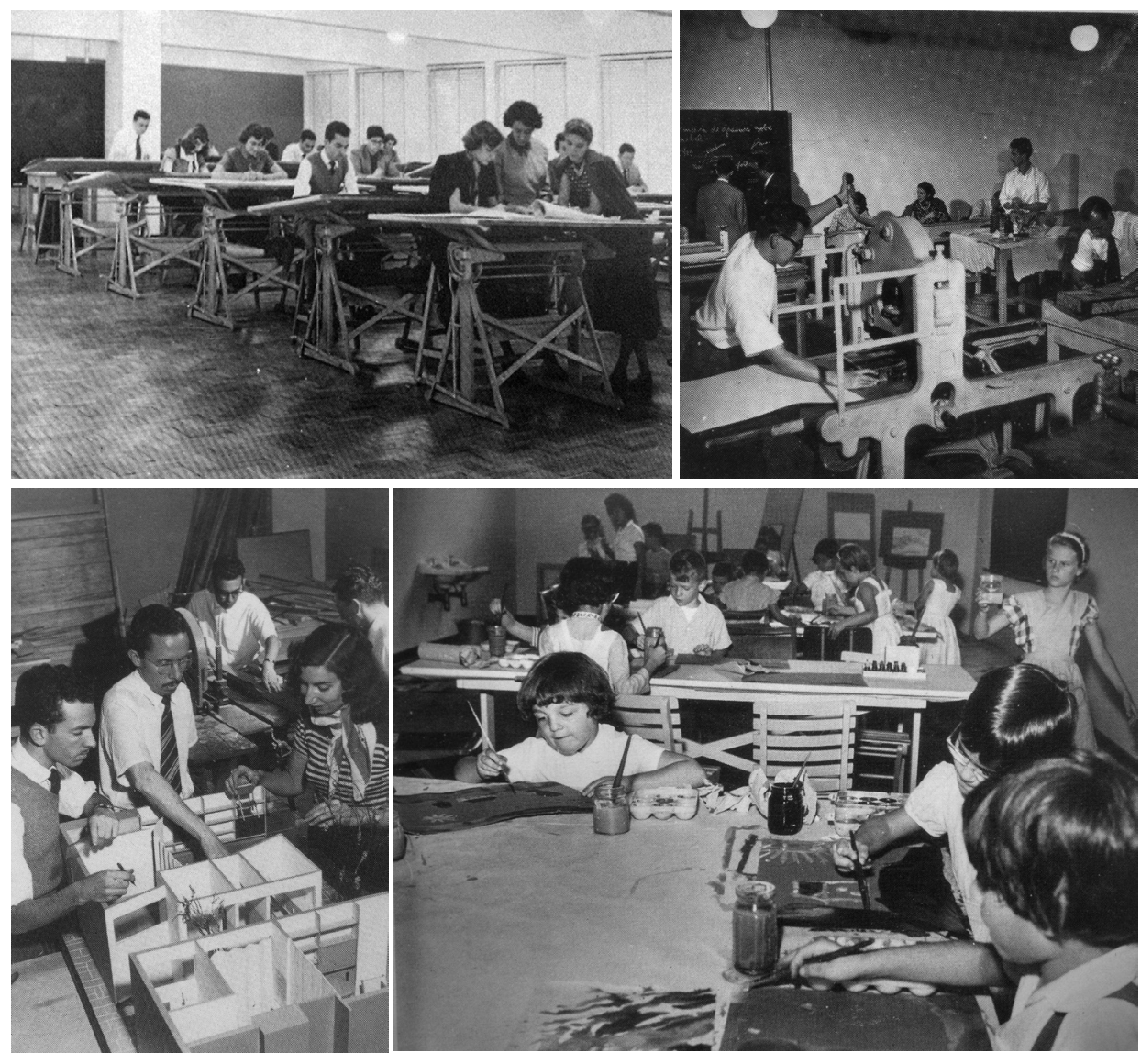

Imagens dos cursos oferecidos pelo MASP. Fonte: BARDI, P. M. (1986) p. 45. 
Na primeira adaptação do espaço promovida por Lina, os $1000 \mathrm{~m}^{2}$ disponíveis precisaram ser bastante segmentados para dar conta de todas as funcionalidades desejadas. Uma grande área foi planejada para ser ocupada por exposições didáticas, a mais importante iniciativa do Museu naquele momento - e que tinha como objetivo atrair jovens para visitar a pinacoteca, que ganhava corpo continuamente. O desejo de Lina era que o museu se constituísse a partir de uma planta livre, o que nesse momento era bastante complicado já que eram previstas atividades demais para metros quadrados de menos.

Nas palavras de Lina Bo Bardi sobre o sentido da organização dos espaços e da proposta de percurso para o MASP Sete de Abril:

O fim do museu é o de formar uma atmosfera, uma conduta apta a criar no visitante a forma mental adaptada à compreensão da obra de arte, e nesse sentido não se faz distinção entre a obra antiga e uma obra de arte moderna. No mesmo objetivo a obra de arte não é localizada segundo um critério cronológico, mas apresentada quase propositadamente no sentido de produzir um choque que desperte reações de curiosidade e de investigação.

E continua:

Encaminhando o visitante para a pinacoteca, que se formou num sistema misto, em que se reúnem quadros, esculturas e objetos, a exposição didática apresenta em uma síntese de fotografias, reproduções em cores e documentos, o panorama histórico do desenvolvimento da arte nos diversos países, ou trata de períodos ou movimentos particularizados.

As exposições didáticas iniciaram o trabalho de Lina e Pietro no sentido de "formar" um público preparado para fruir a coleção que seria apresentada. Importa ressaltar que, nesse primeiro momento, o desenho de Lina propõe uma ruptura com os padrões museográficos brasileiros. A arquiteta adota estruturas tubulares para construir um percurso linear de forma que o visitante possa acopanhar o desenvolvimento do pensamento proposto nos painéis. Não havia, nessa proposta, muitas outras maneiras de se relacionar com o conteúdo a não ser completando a volta em torno dessa estrutura, e isso tinha a ver com o caráter educativo proposto para tal. $\mathrm{E}$ isso, claro, criava uma possibilidade de controle maior por parte de Lina da fruição que o visitante teria desse espaço. Ao mesmo tempo, a arquiteta já apontava para um desejo de flutuação no ambiente: os painéis - que não tocavam o chão ou o teto, a não ser pelas finas estruturas tubulares davam a sensação de um espaço mais amplo e interconectado.

Na foto da próxima página, podemos ver a sala da Pinacoteca montada para a inauguração do museu, em 1947. Conforme explica Pietro Maria Bardi em seu livro “40 Anos de MASP”, as pinturas foram fixadas em tubos de alumínio para afastá-las das paredes por causa da umidade, pois o edifício ainda encontrava-se em construção. A solução - muito similar à adotada por Franco Albini em sua exposição "Il Scipione", em 1941 - parece funcionar, nesse caso, somente para criar essa necessária distância da parede, e não para construir um efeito visual específico de flutuação, que veremos mais à frente no MASP da Paulista. Os quadros nessa primeira situação encontram-se quase colados às paredes, da maneira como costumamos ver em museus tradicionais - porém fixados em barras metálicas. O recurso, curiosamente, é usado também quando os quadros circundam os pilares, provavelmente no intuito de fazer o melhor aproveitamento do exíguo espaço disponível. Alguns poucos quadros ganhavam o espaço e se apresentavam soltos, distanciados de pilares ou paredes, podendo ser circulados. Assim, o recurso da haste parece não ter um discurso tão afirmativo de descolamento das paredes quanto outras soluções que Lina desenvolveria em breve.

Mesmo considerando que o percurso criado pela configuração dos espaços não eram totalmente inovadores se olharmos para o que estava sendo produzido como linguagem na Itália,, a transparência gerada entre os quadros - principalmente nos posicionados no meio da sala - davam a sensação de ampliação do salão, ajudando a amenizar as limitações produzidas pelo espaço exíguo. Apesar de ser uma espécie de revisitação ao desenho de display de Eduardo 


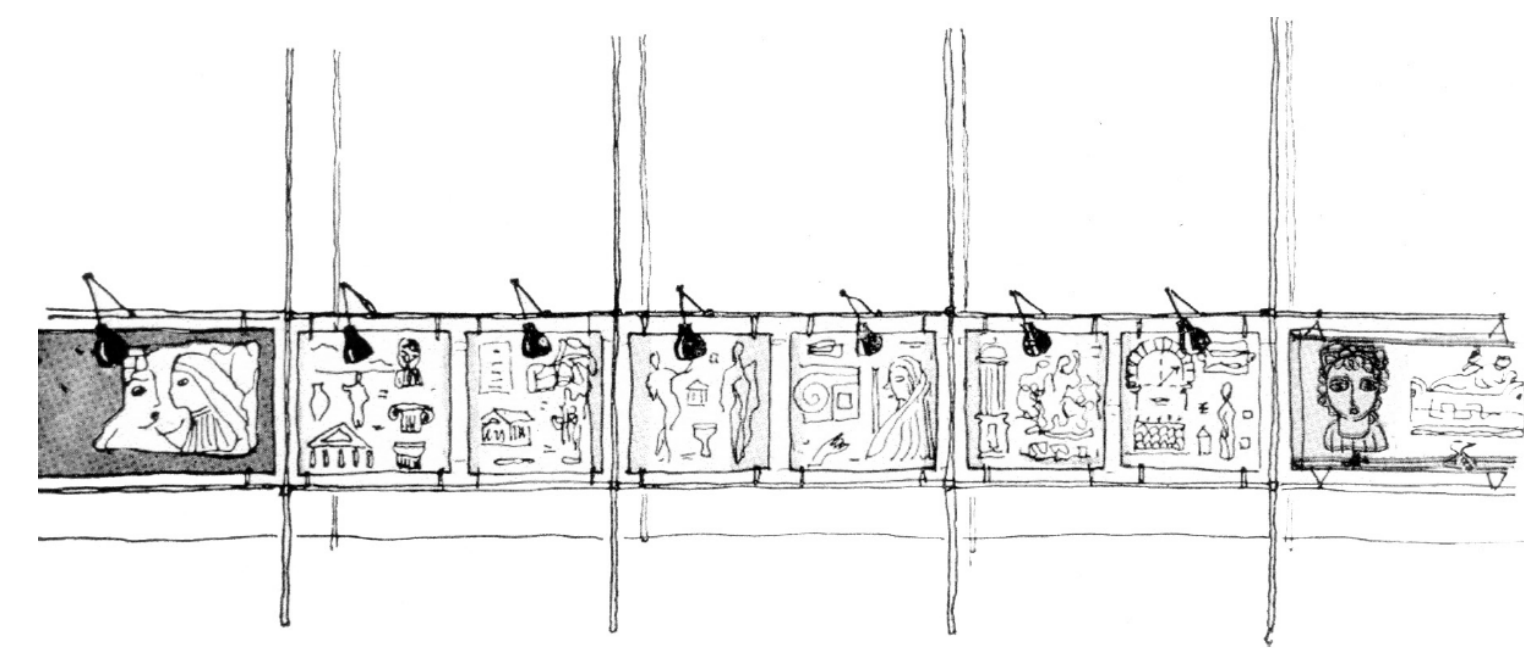

Desenho do sistema projetado por Lina Bo Bardi para as mostras didáticas,

possibilitando a organização por módulos. Fonte: SCHINCARIOL, Zuleica. Através do

na 7 de Abril, p. 59.

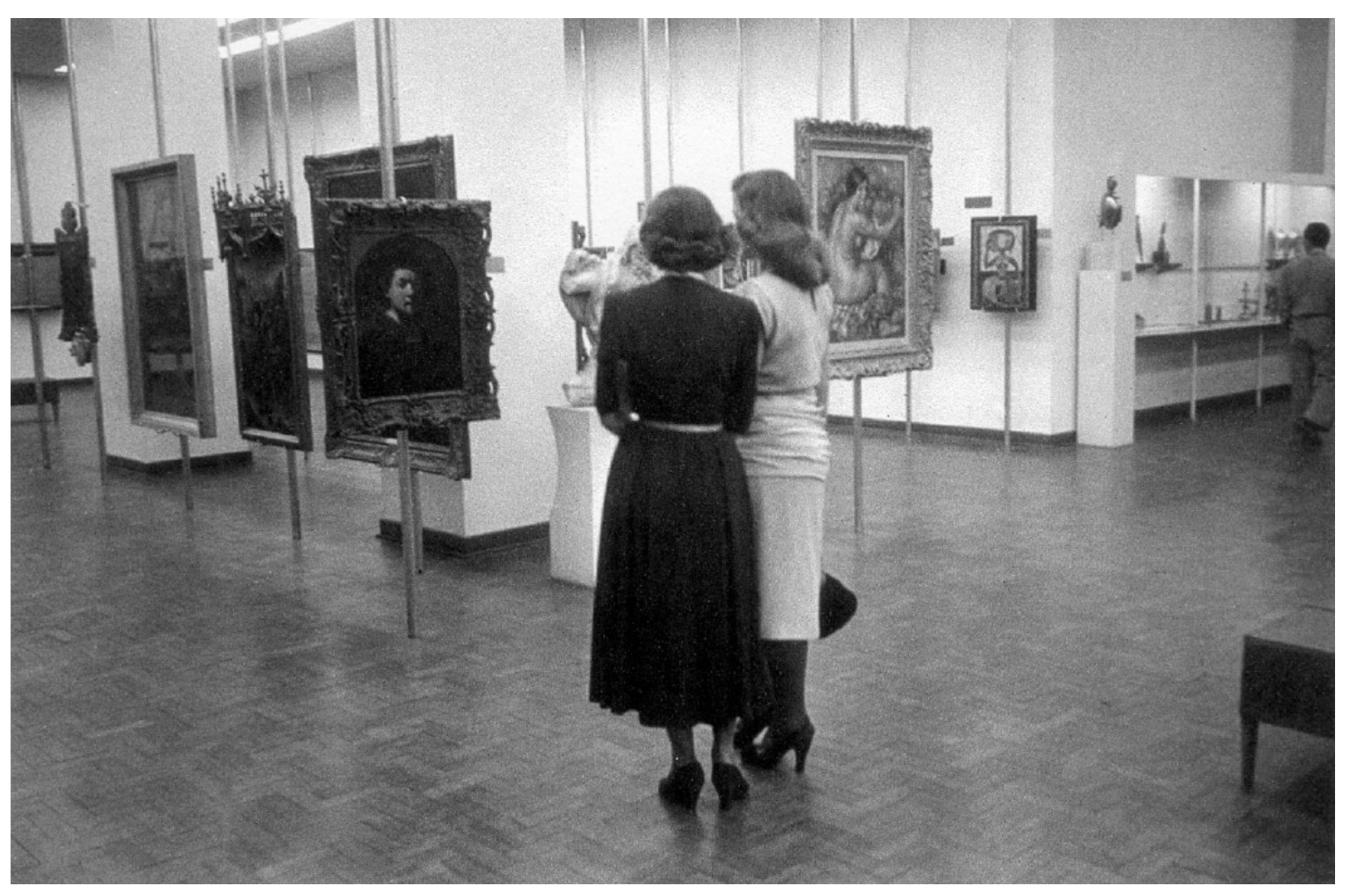

A configuração da pinacoteca na época de sua inauguração. Fonte: BARDI, P. M. (1992).
P. 98 .
Pérsico, de 1941, o sistema já era bastante ousado para os padrões conservadores do Brasil.

Rapidamente, o MASP foi se tornando referência e contava com um número cada vez maior de visitantes. Por conta do grande público interessado nos cursos e do crescimento do acervo, três anos após sua inauguração, o MASP fecha as portas para uma ampliação. É, então, reinaugurado em 1950 com cinco andares. O terceiro andar era inteiramente dedicado à pinacoteca e não contava com paredes divisórias. Nesse espaço, os quadros da coleção eram fixados em placas sustentadas por cabos de aço atirantados e equilibradas no solo por finíssimos pés fixados nas extremidades de cada placa. Houve nesse momento uma grande evolução na qualidade de iluminação do ambiente. Agora a instituição também contava com ateliers mais bem equipados e uma biblioteca com título de peso. Houve, nesse momento, uma grande evolução na qualidade de iluminação do ambiente. Desde então, o museu começa a abrir as portas para obras de arte contemporâneas.

Apesar de o pensamento por trás desse tipo de display ter uma raiz facilmente identificável na arquitetura moderna italiana, o conceito de museu didático, pedagógico e dinâmico nasce nos Estados Unidos a partir de 1930

O MoMA - Museu of Modern Art - vinha, há algum tempo, desenvolvendo experiências que trabalhavam com o caráter didático das exposições.

O modelo adotado pelo MoMA definiu a orientação de grande parte das novas instituições voltadas para a arte moderna criadas no pós-guerra, impulsionando a criação de vários museus e institutos com orientação educativa e formadora para as práticas artísticas modernas. ${ }^{20}$

Vários outros sistemas de displays foram desenvolvidos ao longo dos anos no MASP da Sete de Abril, e a criação de cada um deles 

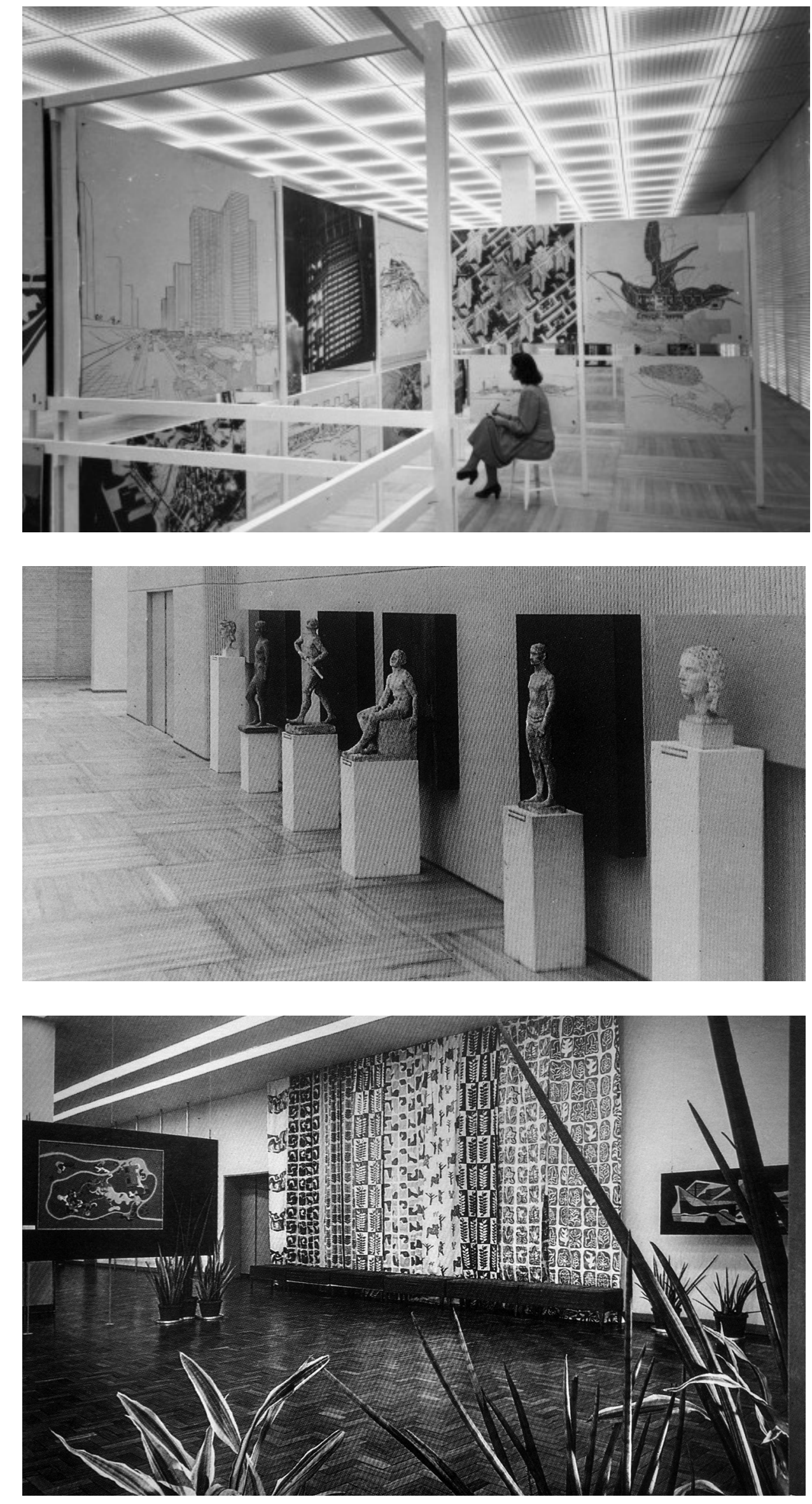

De cima para baixo: Exposição de Le Corbusier (1950), Ernesto Fiori (1947) e Roberto Burle Marx (1952). Fonte: BARDI, P. M. (1992). P. 94. estava ligada a especificidades de cada nova exposição. O MASP estava sempre financeiramente limitado, portanto as soluções precisavam ser simples e não onerosas. As contribuições de Lina, nesse sentido, são visíveis, visto que desenvolvia sistemas replicáveis e adaptáveis às mais variadas situações.

O critério que informou a arquitetura interna do Museu restringiuse às soluções de 'flexibilidade', à possibilidade de transformação do ambiente, unidos à estrita economia que é própria de nosso tempo). ${ }^{27}$
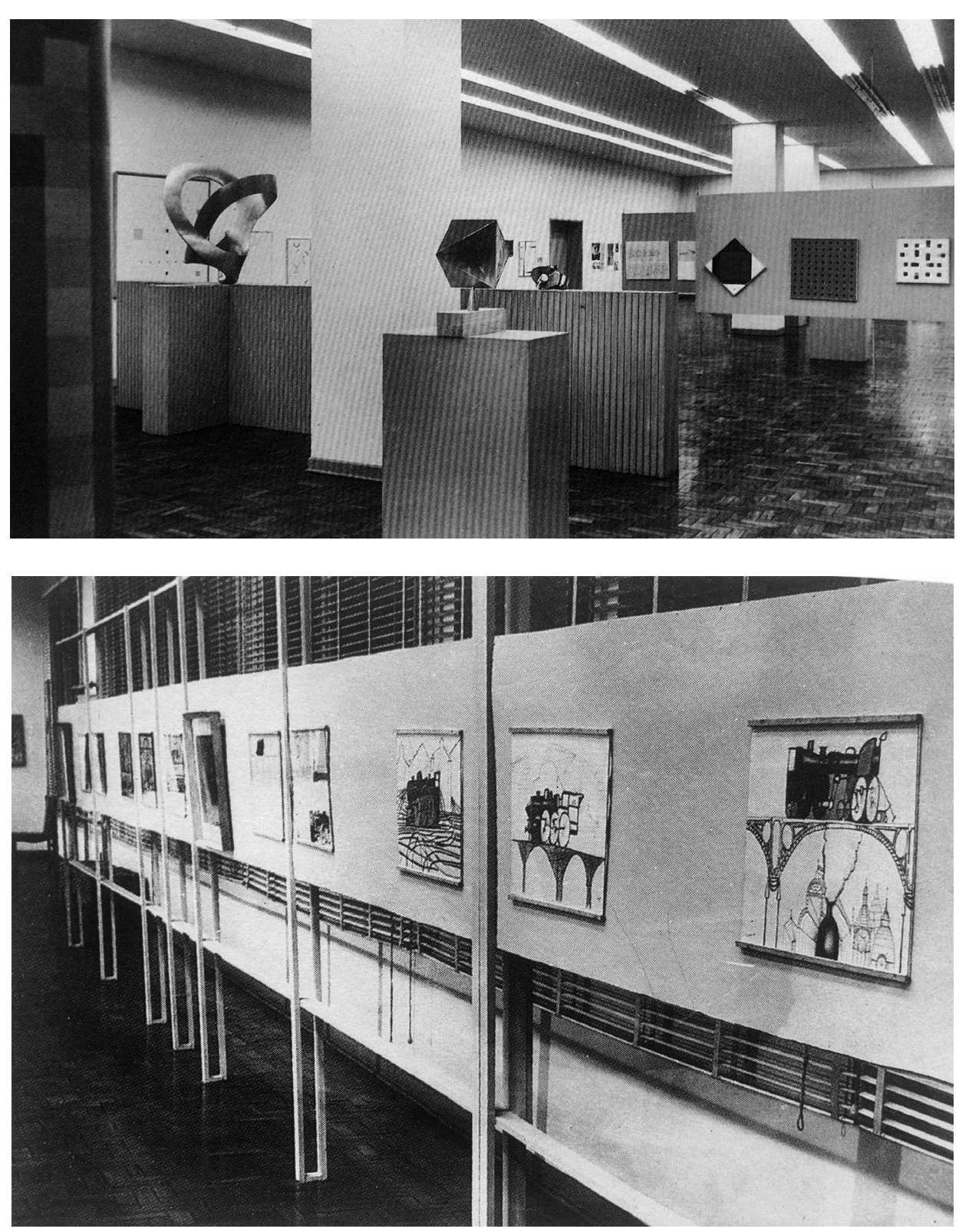

Exposições de Max Bill (1951) e Saul Steinberg (1952). Fonte: BARDI, P. M. (1992). P. 93.

21 FERRAZ, Marcelo (coord.). Lina Bo Bardi. São Paulo: Empresa das Artes, 1993. Pg. 46 


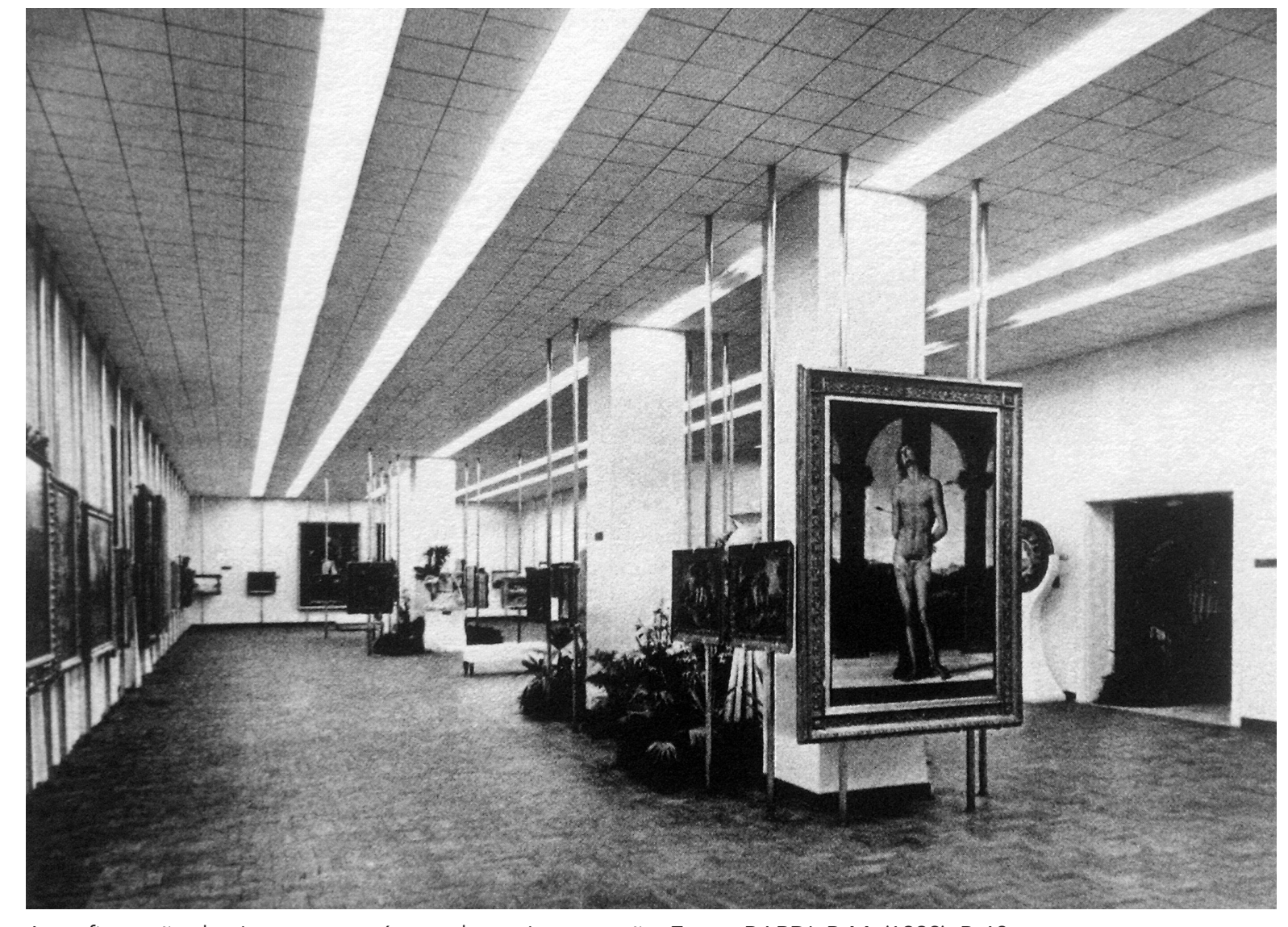

A configuração da pinacoteca na época de sua inauguração. Fonte: BARDI, P. M. (1992). P. 60.

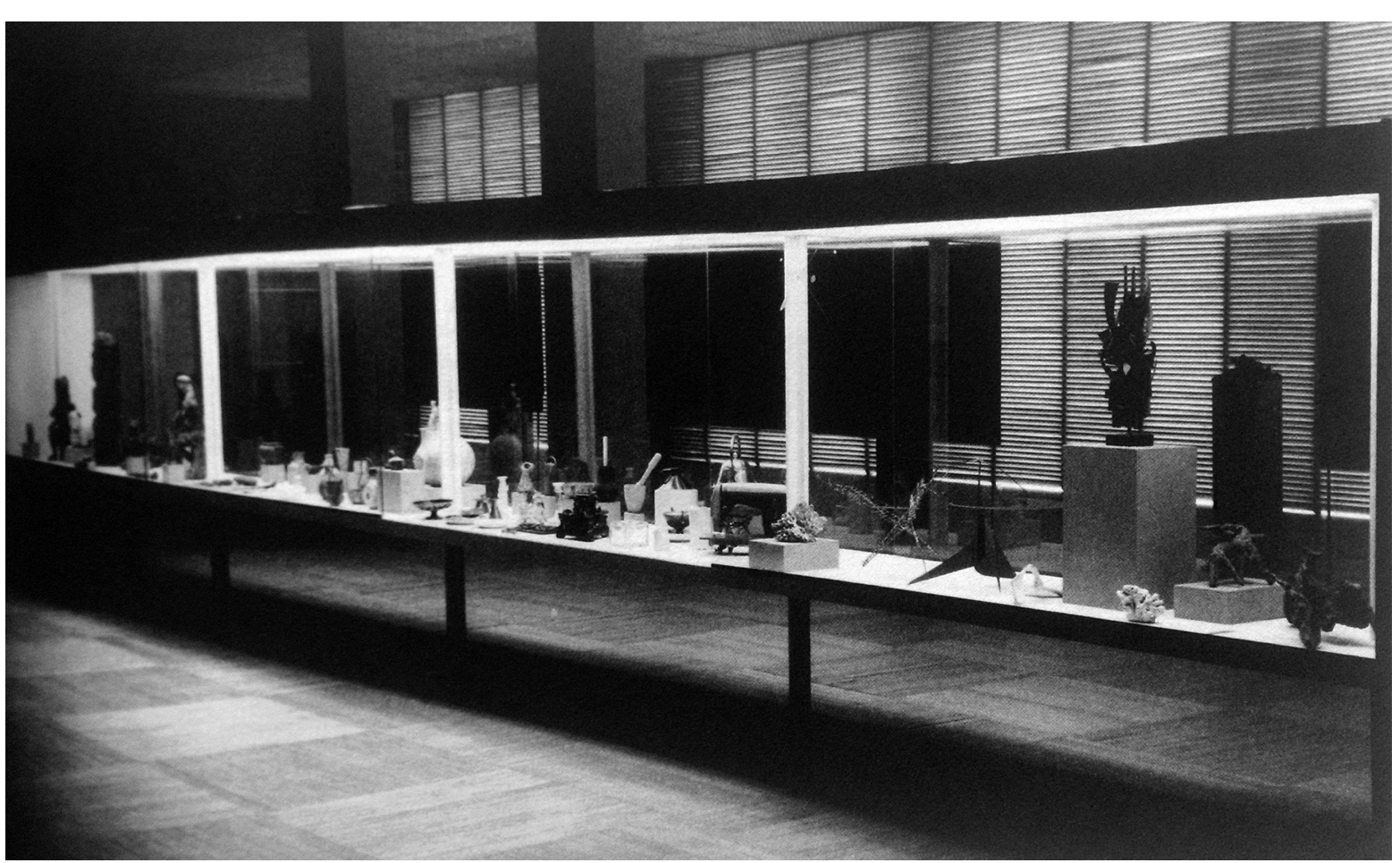

Vitrine das formas: display desenvolvido para exibir peças de diversas culturas e períodos

no mesmo espaço. Fonte: LATORRACA, G. (2014). P. 43.
Em 1957, quando o espaço da Sete de Abril, mesmo ampliado, já não dava mais conta da coleção nem da crescente demanda de cursos, Pietro Maria Bardi teve a ideia de negociar uma parceria com a recém-inaugurada Fundação Armando Alvares Penteado, a FAAP no bairro do Pacaembu. Sua proposta era que eles abrigassem a coleção do MASP e incorporassem a ela as obras da coleção da própria universidade. Como a estrutura dessa instituição já estava montada e contava com espaço adequado e amplo para ensino, todos os cursos do IAC foram, junto com a coleção, também remanejados para lá. O que se passou foi um episódio confuso que Bardi (1992) descreve a seguir:

Nossas obras chegaram a ser colocadas para uma experiência, nas salas da Fundação, porém a qualidade de algumas peças a serem incorporadas à coleção era questionável. Perturbado pelas dúvidas, observei que assim não se poderia fazer o convênio e tomei uma decisão imediata: rocambolescamente voltei com tudo para a Rua Sete de Abril com a aprovação de Edmundo. Este episódio teve como única consequência a permanência dos cursos criados pelo Museu na FAAP.

Antes dessa breve ida da coleção para a FAAP, Lina já havia começado a esboçar ideias de uma sede construída do zero, antevendo a saturação do espaço atual, principalmente, por conta dos cursos. Porém, com esse movimento de retorno da coleção para a Sete de Abril e a permanência dos cursos na FAAP, acabou-se liberando um espaço considerável no MASP, o que freou o início imediatoda construção da nova sede. Lina, frustrada com a diminuição da marcha, deixou de participar ativamente das atividades do MASP e seguiu, a convite do governador Juracy Magalhães para a Bahia, onde permaneceu por cinco anos. Apesar disso, no fim desse mesmo ano, o início das obras do que seria o novo Museu é viabilizado, e Lina estabelece uma metodologia de trabalho que equilibra idas e vindas entre Salvador e São Paulo.

É fundamental destacar a importância que esse primeiro momento do MASP, na Sete de Abril, teve para o desenvolvimento do projeto 
de museu que Pietro Maria Bardi e Lina Bo Bardi almejavam. O pesquisador Adriano Tomitão Canas chama essa fase de "laboratório do moderno" ${ }^{2}$. Foi nesse espaço que Pietro Maria Bardi e Lina Bo Bardi deram corpo aos conceitos que vinham sendo debatidos internacionalmente sobre a função dos museus após as duas Grandes Guerras. Pietro destaca em vários de seus textos que o que eles pretendiam com o projeto do MASP era criar uma espécie de "antimuseu" - um museu que se descolasse da tradição consolidada na Europa, e que construísse novas camadas de compreensão e vivência da arte. E ao se juntar uma museografia arrojada com uma coleção de obras de peso a um amplo espectro de atividades educativas e formativas, o caráter do museu foi se desenhando.

Para Bardi, o museu deveria possuir um "caráter universal e didático", e se fazia necessário em um país novo como o Brasil, onde a fundação de museus estava no início, que a difusão da arte fosse compreendida como um todo, não seguindo os modelos dos museus europeus do séc. XVIII, assim como não se prendendo aos moldes dos museus de arte moderna. Portanto, o museu deveria considerar o "sentido da história e o respeito ao passado", suscitando discussões, novas interpretações e, assim, possibilitar novas experiências nos diversos campos da arte. ${ }^{23}$

isitante lê a legenda em um dos Fonte: LATORRACA, G. (2014). P. 8 . 1957. T, A. T. MASP. Museu Laboratório. Projeto de museu para a cidade: 1947 1957. Tese de Doutorado. São Paulo: FAU-USP, 2010.

23 http://www.vitruvius.com.br/revistas/read/arquitextos/13.150/4450

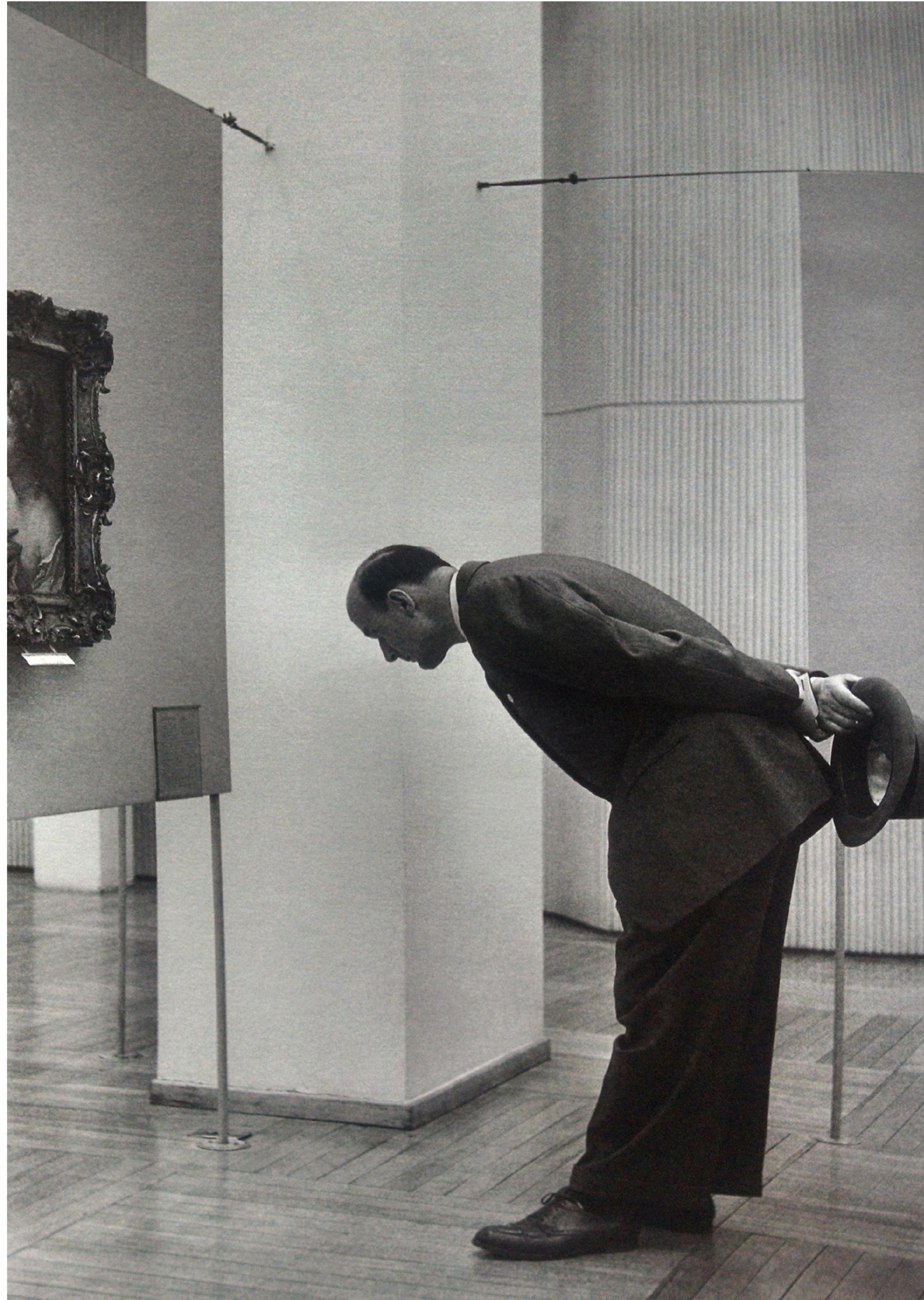


possibilidades de hierarquia de valores. O MASP se implanta, portanto, como um museu de caráter formativo, onde a explicação didática não significa uma doutrinação, mas sim uma formação de sujeitos capazes de elaborar um juízo de valor estético e cultural. ${ }^{25}$

A intenção do casal, conforme muitas de suas declarações à época, era a de formar um público para o museu diferente dos tradicionais e reduzidos círculos de apreciadores de arte. O trecho abaixo é categórico quanto a sua postura em relação à necessidade de uma visão evoluída sobre museus:

O que é um Museu? Correntemente, quando se quer designar uma pessoa, uma coisa, uma ideia antiquada, inútil, fora de uso, costuma-se dizer: é uma peça de museu. Querendo indicar com estas palavras que, no quadro da cultura contemporânea, o museu ocupa lugar poeirento e inútil. [...] O museu moderno tem que ser um museu didático, tem que juntar à conservação a capacidade de transmitir a mensagem que as obras devem ser postas em evidência que diríamos quase da função didática [...]. O complicado problema de um Museu tem que ser hoje enfrentado na base "didática" e "técnica". Não se pode prescindir dessas bases, para não cair em um museu petrificado, isto é, inteiramente inútil. ${ }^{26}$

O que os Bardi buscavam, em última instância, era equiparar o valor da arte antiga ao da produção de vanguarda. Dessa forma, eliminariam o que é conhecido como a "aura" do trabalho - que é o que acaba, muitas vezes, afastando o público não familiarizado de uma compreensão mais acessível do que seja a arte.

Todo esse contexto de pensamento somado à vivência de Lina na Bahia, além de sua forte orientação moderna, foram a base para o desenho do novo prédio. Concebido como uma grande caixa suspensa, de planta livre e fechada fisicamente por duas imensas cortinas

25 http://www.vitruvius.com.br/revistas/read/arquitextos/10.112/22

26 BO BARDI, Lina. Arte Industrial. In: RUBINO, S.; GRINOVER, M.(Orgs.) Lina por escrito. São Paulo: Cosac Naify, 2009, p.109. de vidro, o MASP é um museu transparente. Ele assume características importantes da arquitetura moderna e que são responsáveis por encaminhar o público a uma percepção total e unificada do espaço, compreendido pelo que está em seu interior - pessoas e obras - e o que se encontra fora - vegetação e cidade.

O edifício foi, desde o início, planejado para ser erguido no terreno do antigo Belvedere Trianon, de arquitetura neoclássica, localizado na Avenida Paulista. Era um local frequentado pela alta sociedade paulistana, na época áurea do café e que havia acabado de ser demolido. Lá aconteciam comícios e eventos importantes dentro desse circuito.

A negociação do terreno teve participação fundamental da própria arquiteta, que foi quem criou uma estratégia para convencer o então prefeito Adhemar de Barros a apoiar a construção: garantiu o apoio de todos os canais de mídia que eram de Chateaubriand para a sua candidatura à reeleição.

Junto com o acerto do destino do terreno, foi deixado claro que havia uma exigência: "O terreno era da Prefeitura de São Paulo e seu doador, Joaquim Eugênio de Lima, impusera uma exigência: qualquer construção ali realizada deveria manter a vista que se descortinava do centro da cidade.”(BARDI, 1992, p. 31)

Para esse projeto, Bo Bardi afirma ter procurado "uma arquitetura simples, um desenho que pudesse comunicar de imediato aquilo que, no passado, se chamou de 'monumental', isto é, o sentido do 'coletivo', da 'dignidade cívica"' (FERRAZ, 1993, p. 100). Segundo Lina, a objetividade e a racionalidade eram formas de superar a guerra de maneira não nostálgica. A ideia de simplicidade, além de estar vinculada a princípios modernos herdados da travessia pelas guerras - segundo os quais nenhuma arquitetura deveria conter qualquer elemento que não fosse absolutamente necessário - também está bastante ligada à vivência da arquiteta na Bahia, que observava na forma de produção da cultura do nordeste uma importante lição sobre a experiência de simplificação.

Aproveitei ao máximo a experiência de cinco anos passados no Nordeste, a lição da experiência popular, não como romantismo 


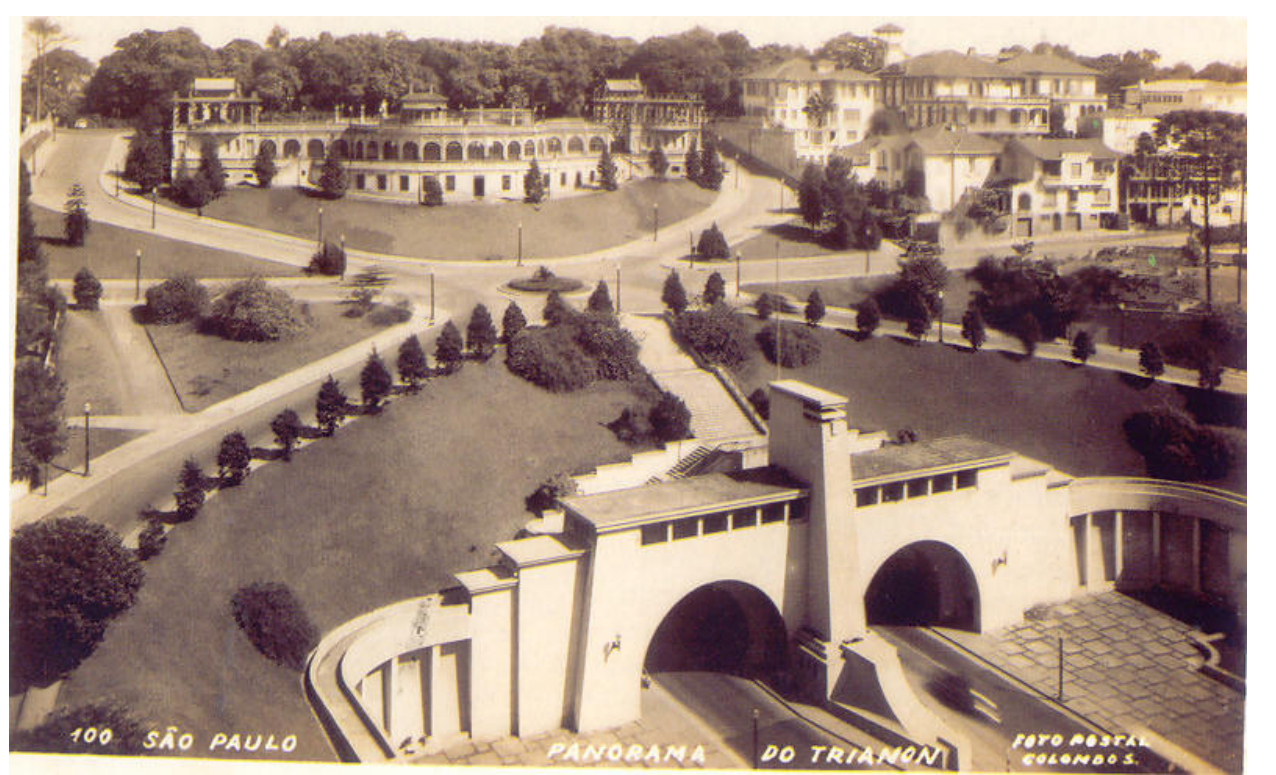

Vista do Belverere Trianon e Túnel 9 de Julho, Cartão postal, 1938. Fonte: São Paulo Antiga

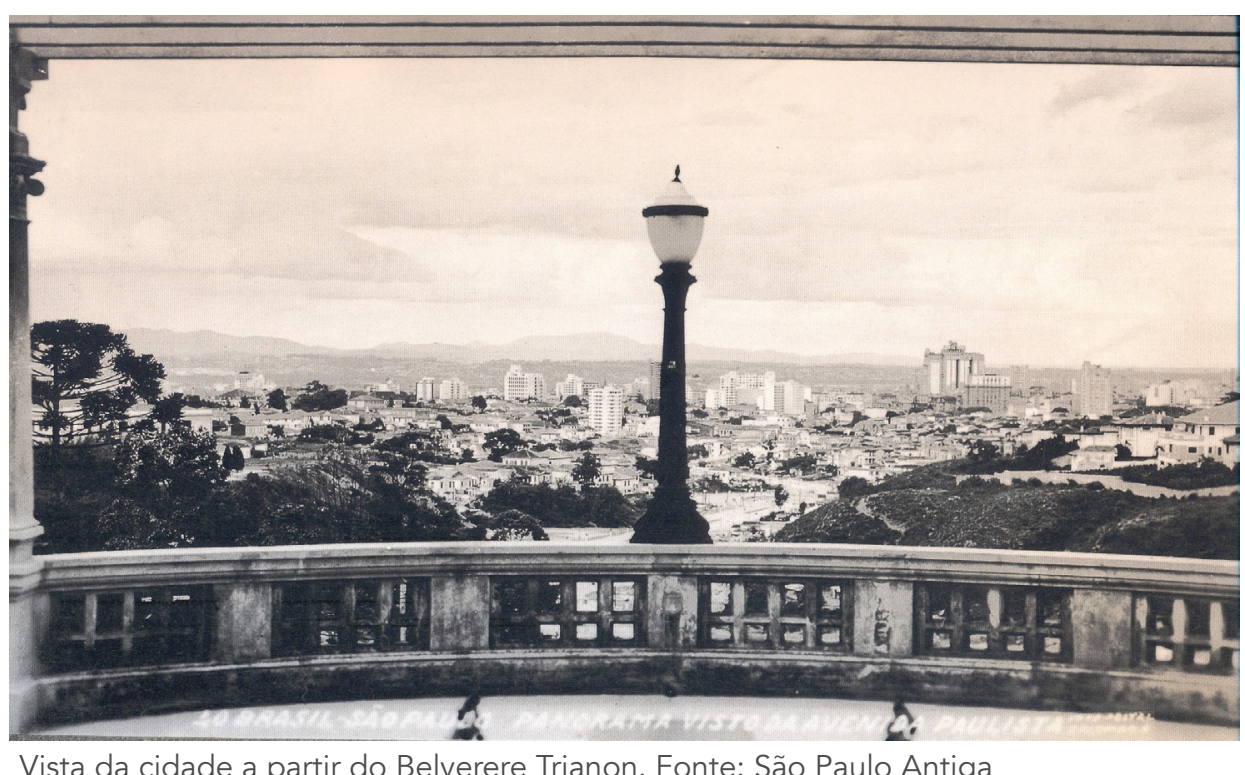

da cidade a partir do Belverere Trianon. Fonte: São Paulo Antiga

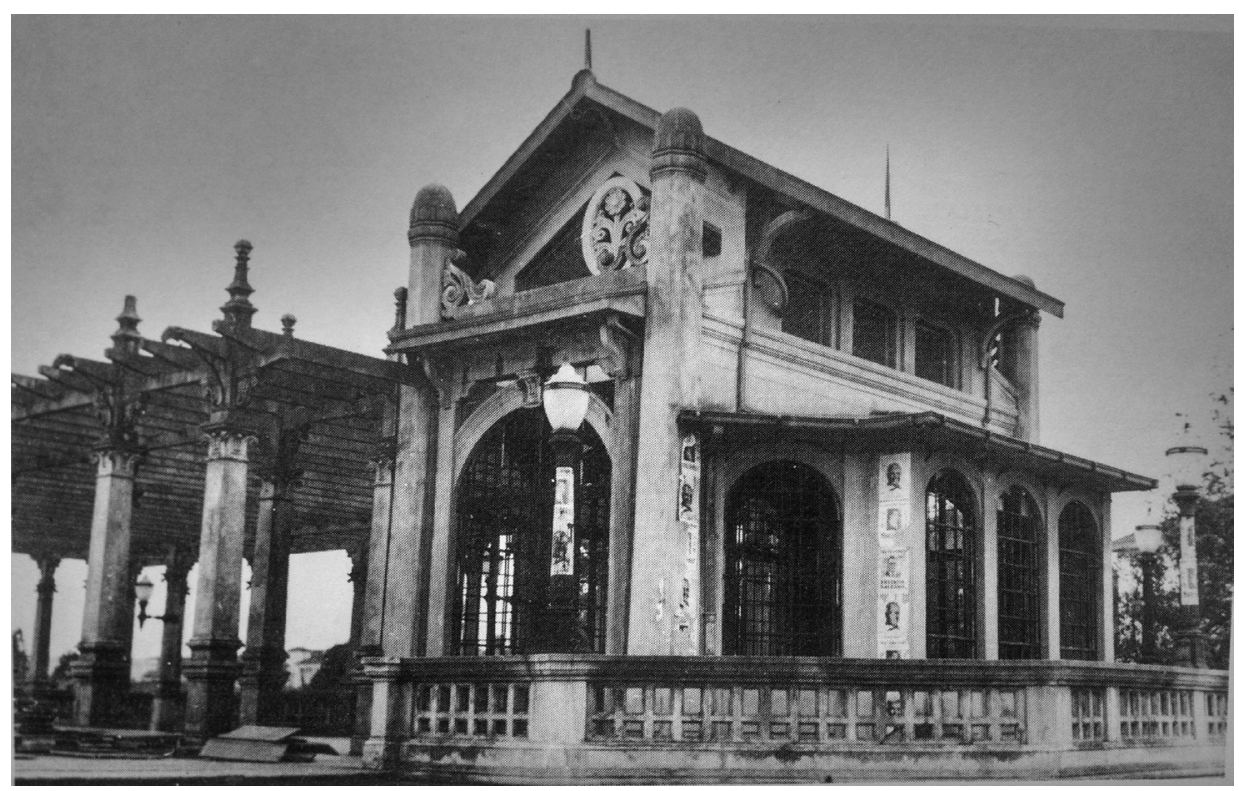

Belvedere Trianon. Fonte: BARDI, P. M. MASP 40 Anos. P. 127 folclórico mas como experiência de simplificação. Através de uma experiência popular cheguei àquilo que poderia chamar de Arquitetura Pobre. Insisto, não do ponto de vista ético. Acho que no Museu de Arte de São Paulo eliminei o esnobismo cultural tão querido pelos intelectuais (e os arquitetos de hoje), optando pelas soluções diretas, despidas" concluindo ainda, sem negar sua monumentalidade, que "o conjunto do Trianon vai repropor na sua simplicidade monumental, os temas hoje tão impopulares do racionalismo. ${ }^{27}$

Lina continua a detalhar o projeto durante os anos em que residiu na Bahia. A construção é iniciada ao final do mesmo ano de 1957 Mesmo sendo o seu primeiro projeto de grande porte a ser encaminhado para construção, a base inspiradora provém claramente de esboços desenvolvidos anteriormente para o Museu à Beira do Oceano, de 1951 - planejado para a cidade de São Vicente, porém nunca construído. Podemos identificar nesse projeto elementos que determinam a arquitetura do MASP: uma caixa retangular suspensa por pilares vermelhos - nesse caso, o número de pilares eram cinco e não dois.

A suspensão do bloco, no caso do Museu à Beira do Oceano havia sido adotada por conda de o projeto ter sido pensado para ser construído na areia, e iria sofrer todas as consequências da umidade e maresia presentes naquele local. Neste projeto era também evidente a importância que a arquiteta dava à relação entre espaço interno e externo - paisagem e arte - que também seriam componentes fundamentais na idealização do MASP. O fato de o terreno do novo MASP apresentar a demanda de conservar a vista desimpedida do antigo belvedere certamente foi uma das razões de Lina ter voltado a olhar para o Museu à Beira do Oceano como um partido em potencial. Estava já no discurso de Lina nesse primeiro momento também o desejo de inocular o olhar moderno no Brasil:

27 FERRAZ, Marcelo (coord.). Lina Bo Bardi. São Paulo: Empresa das Artes, 1993. Pg. 102. 

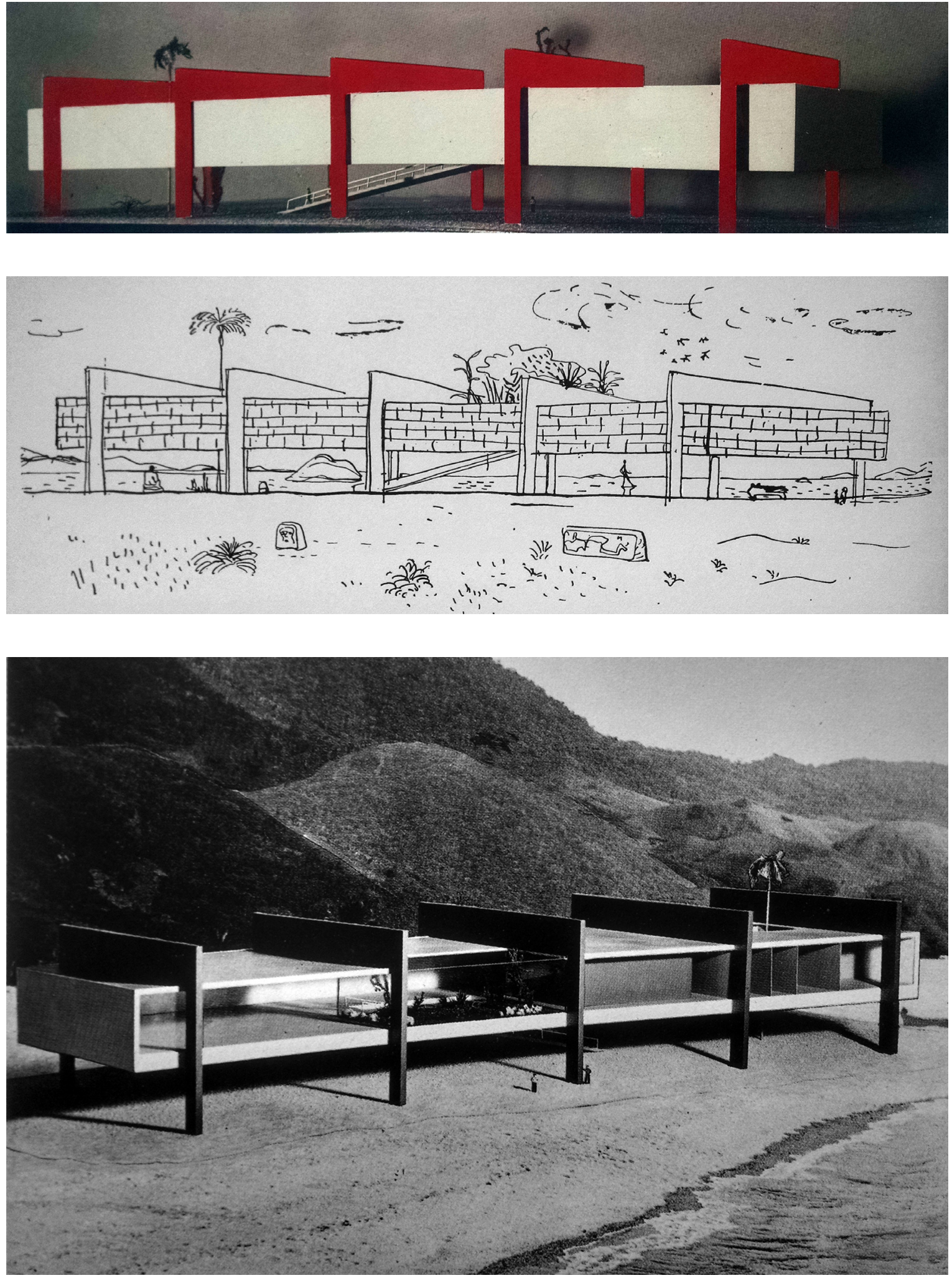

Maquete, desenho e montagem fotográfica para o Museu à Beira do Oceano, 1951. Fonte: SUZUKI, M. (1993). P. 90
“O museu de São Vicente deverá existir como um organismo através do qual o homem da cidade possa tornar-se, aos poucos, contemporâneo de todo o mundo moderno."${ }^{28}$

Além de uma grande similaridade projetual, podemos olhar para as colagens desenvolvidas por Lina - as quais ilustravam a desejada disposição das obras no interior do espaço - como uma clara referência a intenções para a elaboração da expografia do MASP da Avenida Paulista. Nessas simulações as obras flutuam, sem qualquer indicação de suporte. É como se não houvesse gravidade no espaço e cada peça assumisse o lugar que desejasse, sem rigidez ou estabilidade. De maneira interessante, essas colagens se assemelham muito a outras, feitas por Mies van der Rohe para o "Museu para uma cidade pequena”, de 1941.

Um dado interessante sobre esse projeto de Mies van der Rohe é que foi concebido como utópico, porém estava, de muitas maneiras, próximo a questões que inquietavam Lina:

Em 1943, a revista Architectural Forum encomendou uma série de projetos retratando o ideal de uma pequena cidade americana no pós-guerra. No interior desse museu, fotografias de folhagem e água numa faixa linear sugerem o perímetro de um espaço arquitetônico de outro modo ilimitado. Flutuando no espaço há três obras de arte: a pintura Guernica de Pablo Picasso (1937) emoldurada por duas esculturas de Aristide Maillol - Monumento a Paul Cézanne (1912-25, à esquerda) e Noite (1909, à direita). As obras de arte são elementos arquitetônicos, criando as divisões espaciai que organizam o vasto espaço do museu. Na frontalidade quase agressiva da cena, o espaço do museu é evocado exclusivamente pela orientação vertical desses elementos pictóricos planos na página. A narrativa inquietante de Guernica encena sua própria perturbação mais ao centro da imagem. ${ }^{29}$ 

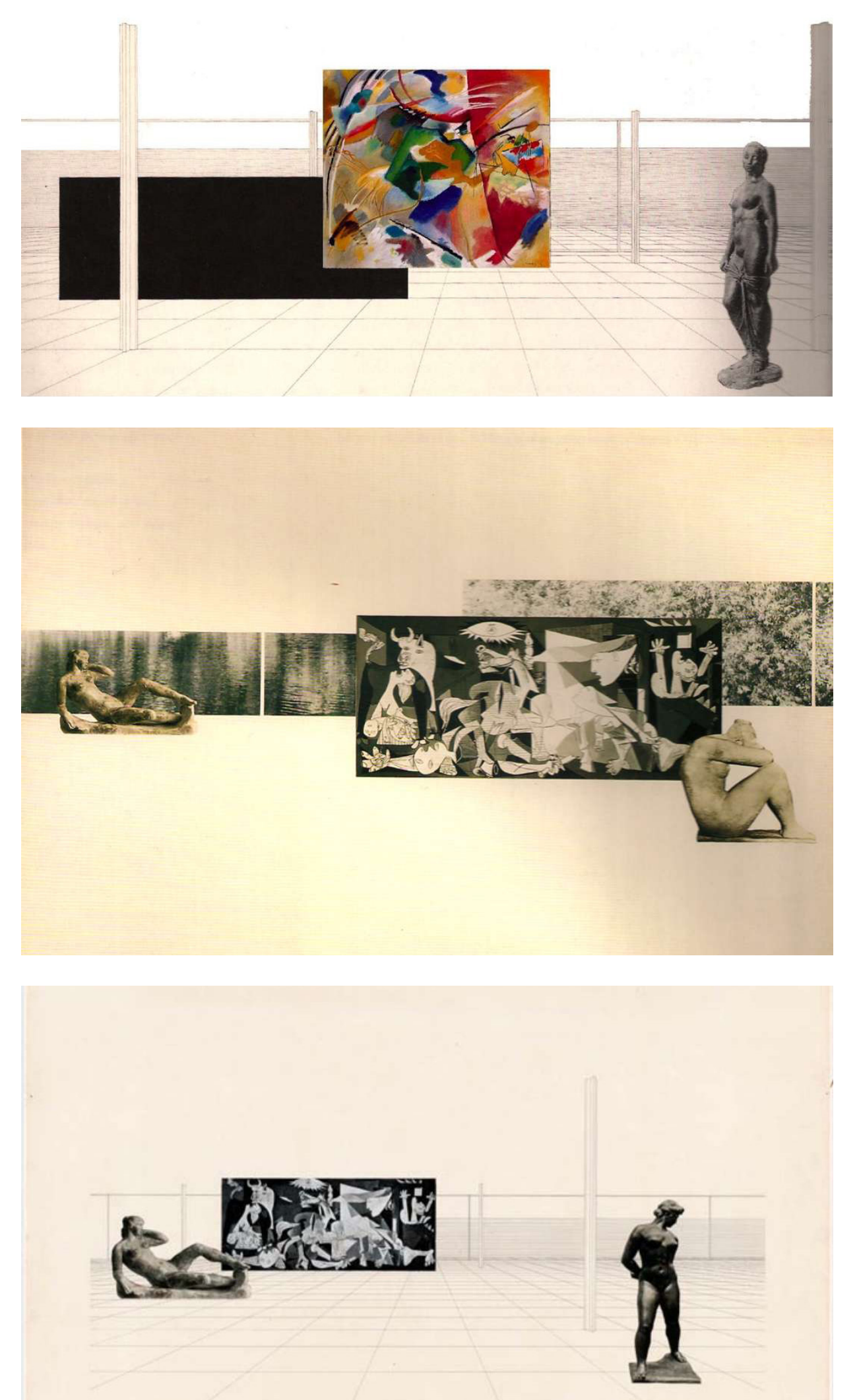
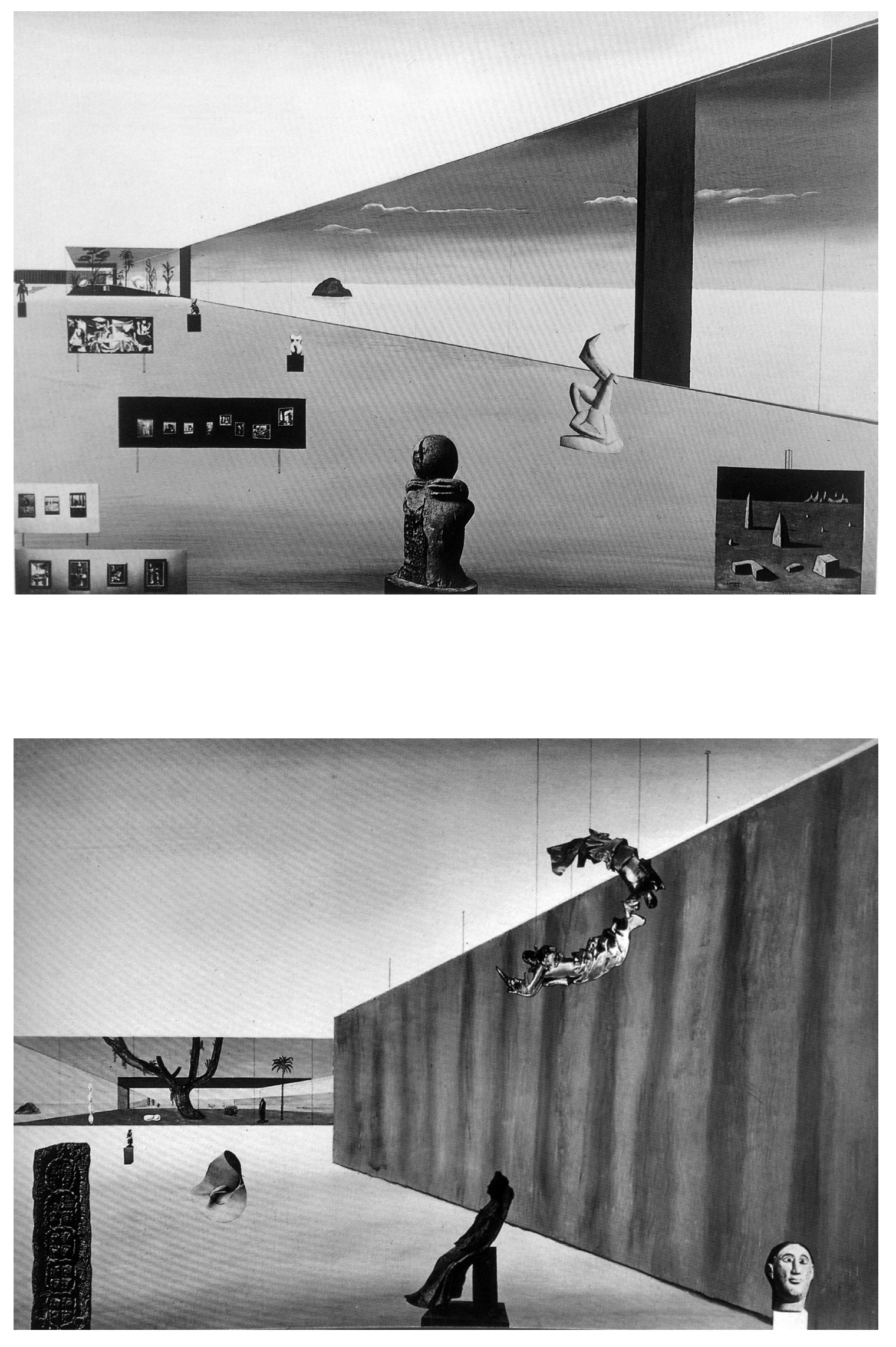

Colagens fotográficas - estudos para área de exposição do museu. Fonte: Fonte: SUZUKI, M. (1993). P. 92 
A problemática imposta pelo pós-guerra, a necessidade de se pensar uma nova forma de (re)construir as cidades, o desenho de uma nova maneira de se relacionar com a arte e a ideia do moderno como caminho para construir esse novo momento da história habitam os desejos tanto de Bo Bardi como de Van der Rohe. Na arquitetura de ambos, A objetividade e a racionalidade eram formas de superar a guerra de maneira não-nostálgica.

Nos desenhos do projeto do MASP, porém, podemos notar uma mudança grande em relação a como representar o espaço de exposição e de circulação do público. Ao contrário da limpeza e precisão adotadas por Mies van der Rohe, e pela prórpia Lina nesse primeiro momento, nos novos desenhos a arquitetura pulsava vida - a cor, a intensa presença humana e um movimento frenético agora assumiam o primeiro plano, deixando de lado a frieza e limpeza típicas das representações da arquitetura moderna. Lina afirmava com isso que estava menos interessada na perfeição, no acabamento, mas na situação de uso que o espaço poderia potencializar.

O edifício do MASP se consolida como uma caixa de luz que ocupa um espaço nobre da capital paulistana, e refresca o entorno cada vez mais saturado ao dar espaço para a transparência e o vazio. $\mathrm{E}$ são em grande medida a suspensão dessa caixa e o envidraçamento que criam essa poética.

\begin{abstract}
A solução de Lina é pujante: organiza o edifício em duas partes, uma totalmente elevada, aérea, cristalina, e outra semienterrada, rodeada de jardins e vegetação. Com essa atitude cria e qualifica o vazio, terceiro elemento que intercala as duas partes. Não só preserva a visão do Parque Trianon sobre a cidade, mas, principalmente, pronuncia essa visão, ao mesmo tempo em que a modifica no ato de emoldurá-la. A cidade vem acolhida nesse vazio, nesse exterior que, podemos dizer como Le Corbusier, é sempre um interior. OLIVEIRA, O. (2006) p. 259
\end{abstract}

As obras, iniciadas em 1957, foram finalizadas somente em 1968 Além de abrigar a coleção de Assis Chateaubriand, foram inaugu-

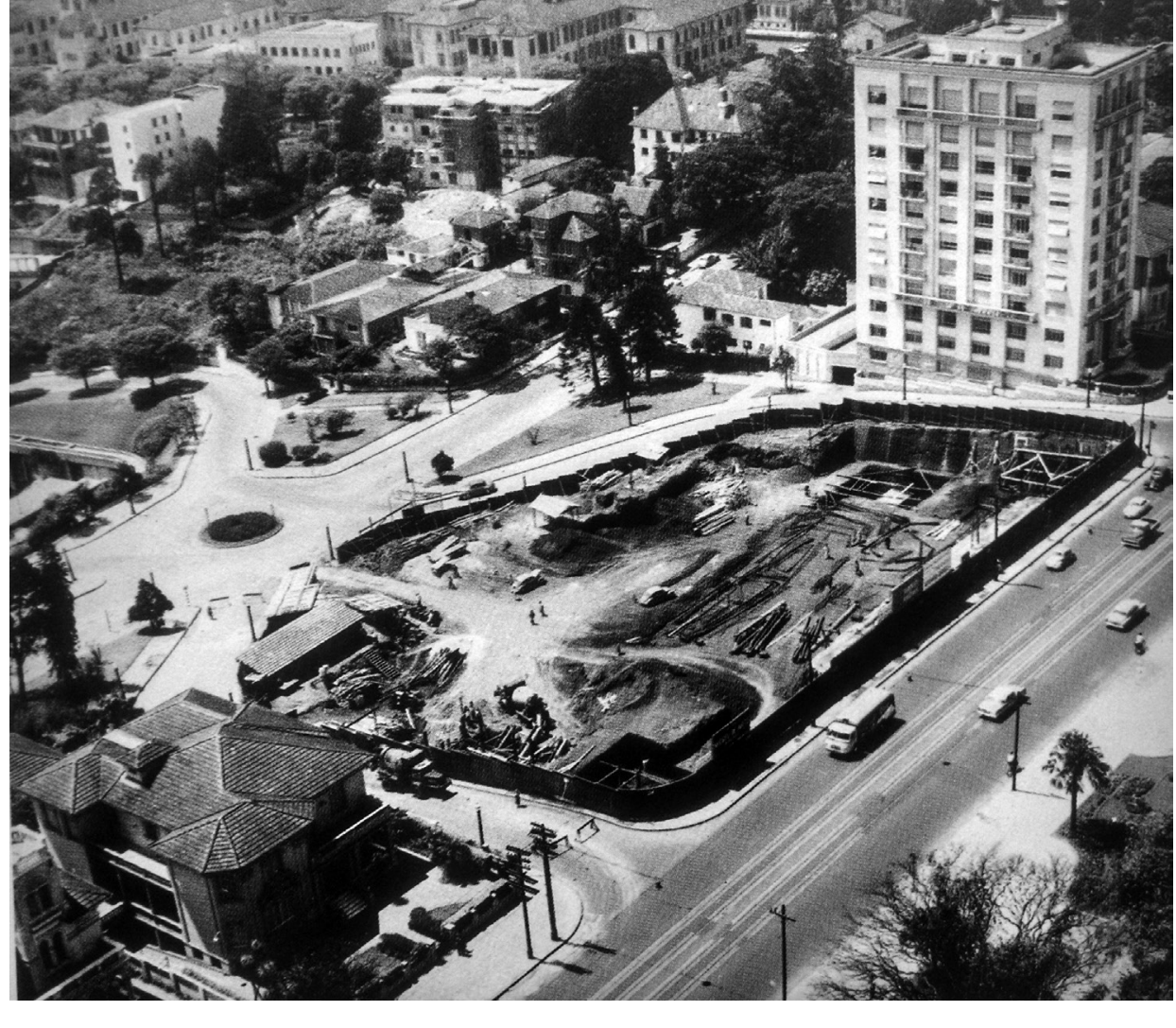

Década de 40: demolição do antigo Belvedere Trianon. Fonte: Fonte: SUZUKI, M. (1993). P. 102

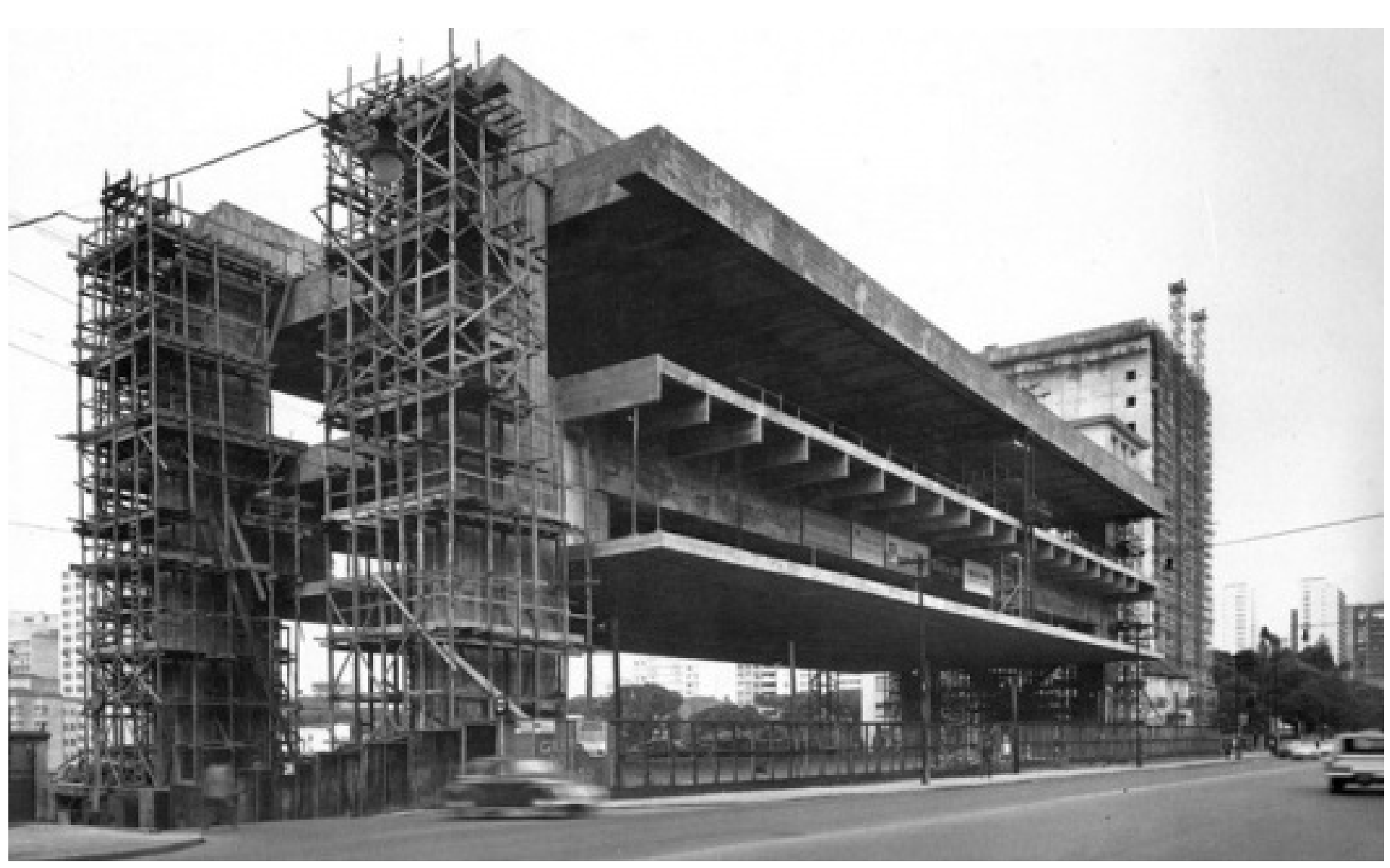

MASP em construção. Fonte: SUZUKI, M. (1993). P. 106 


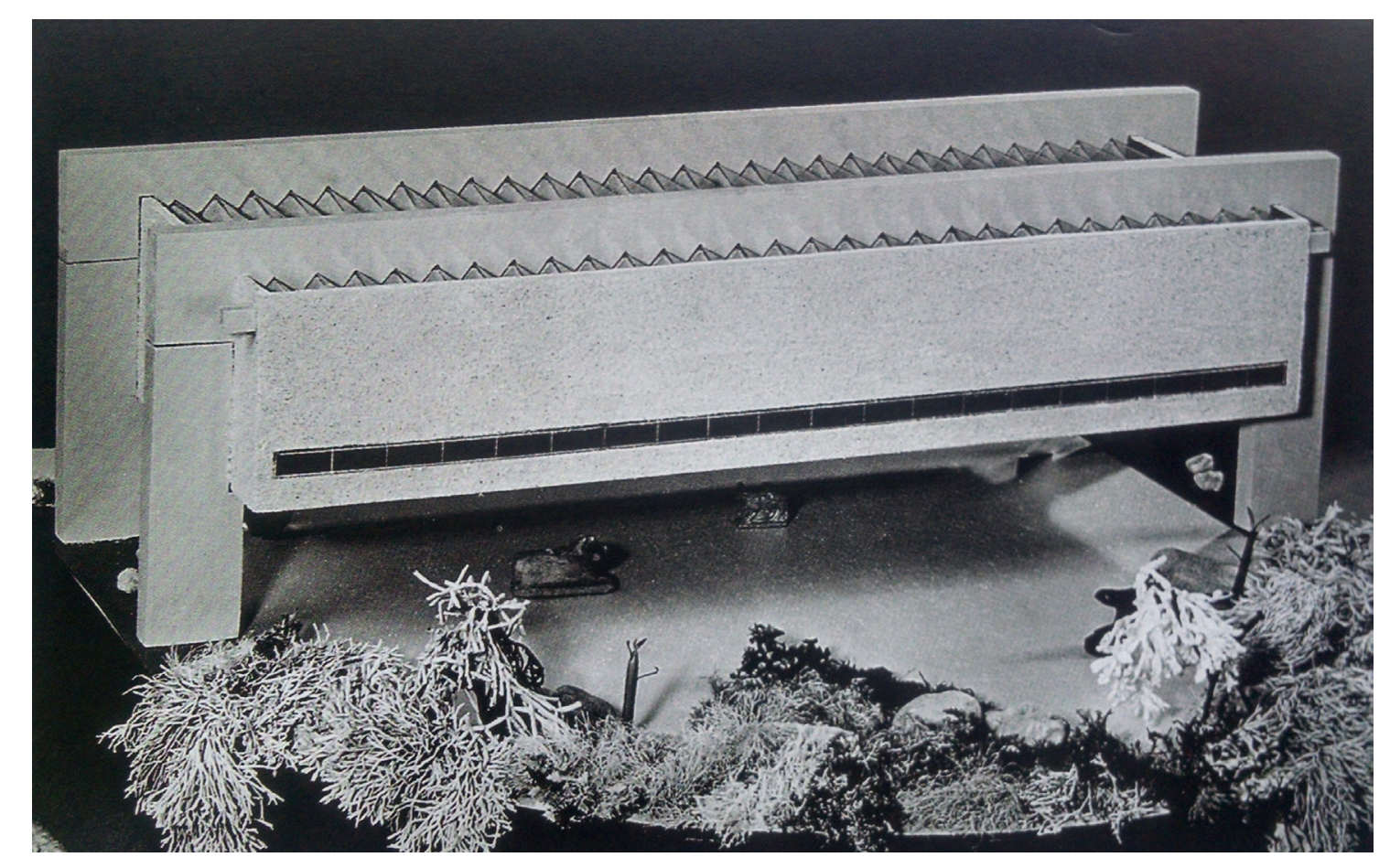

Estudo com a pinacoteca ainda iluminada por "sheds". Fonte: SUZUKI, M. (1993). P. 101.
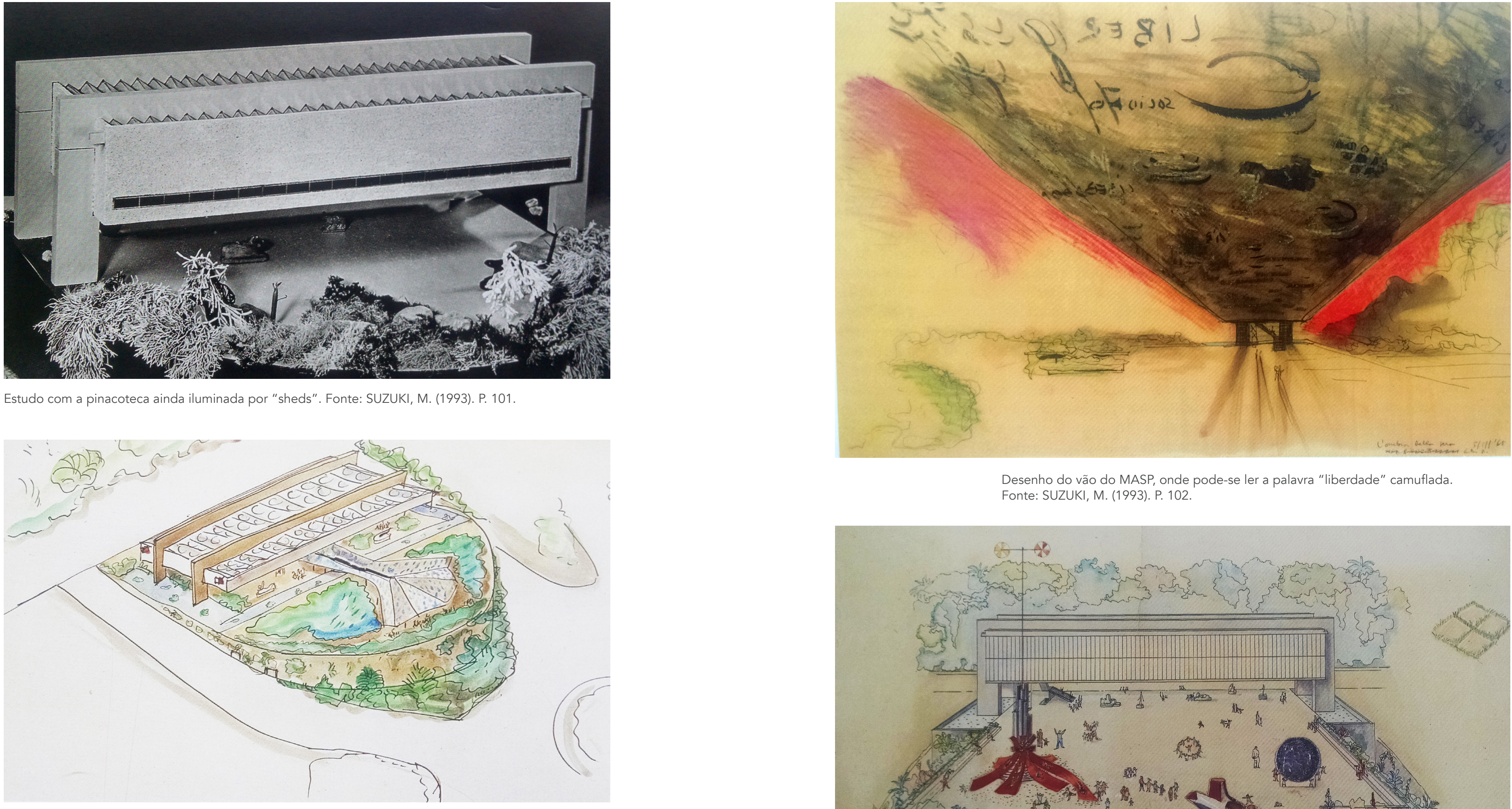

Fonte: SUZUKI, M. (1993). P. 102

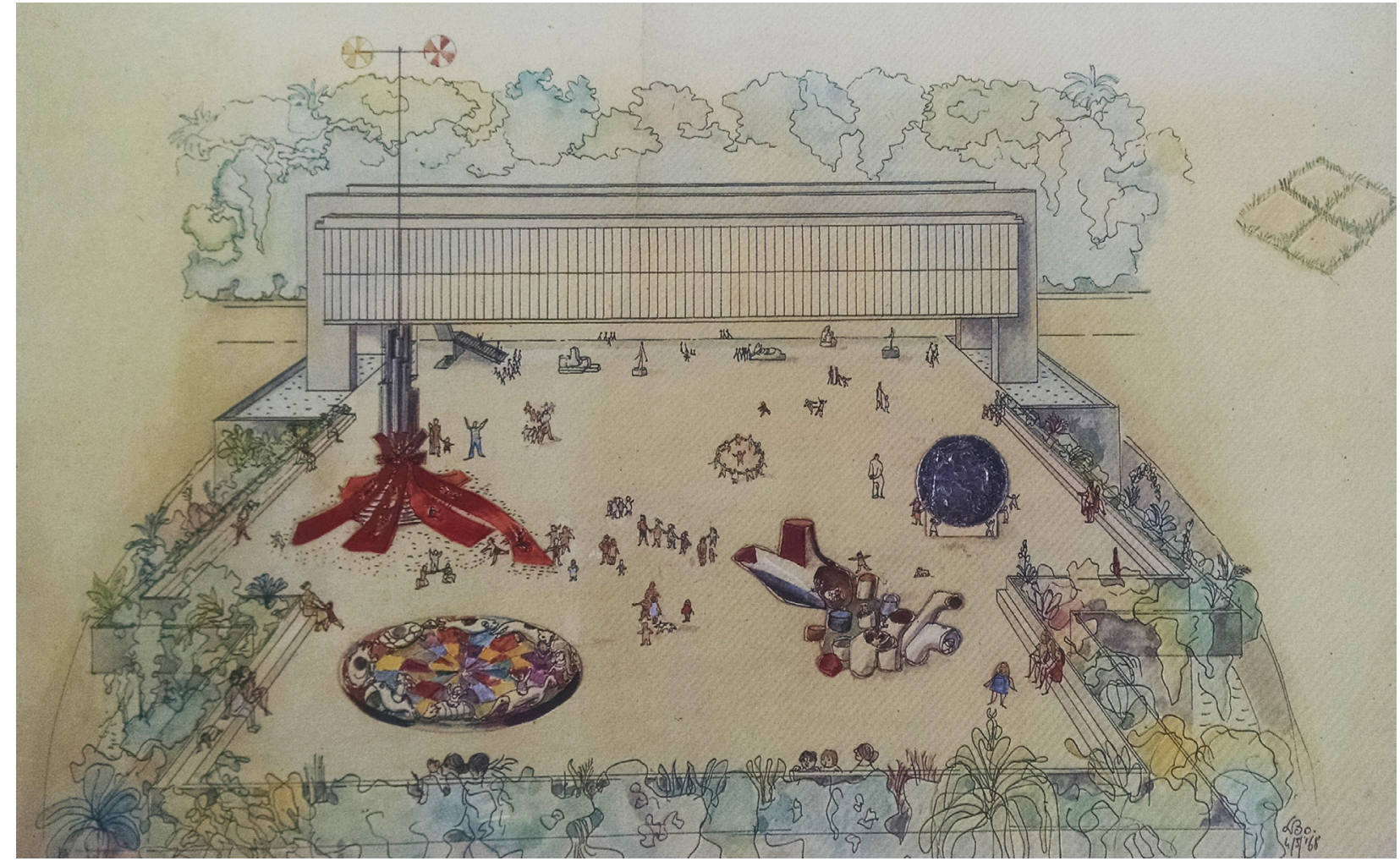
Desenho de Lina ilustrando possibilidades de uso do vão do MASP.
Fonte: SUZUKI, M. (1993). P. 111 . 


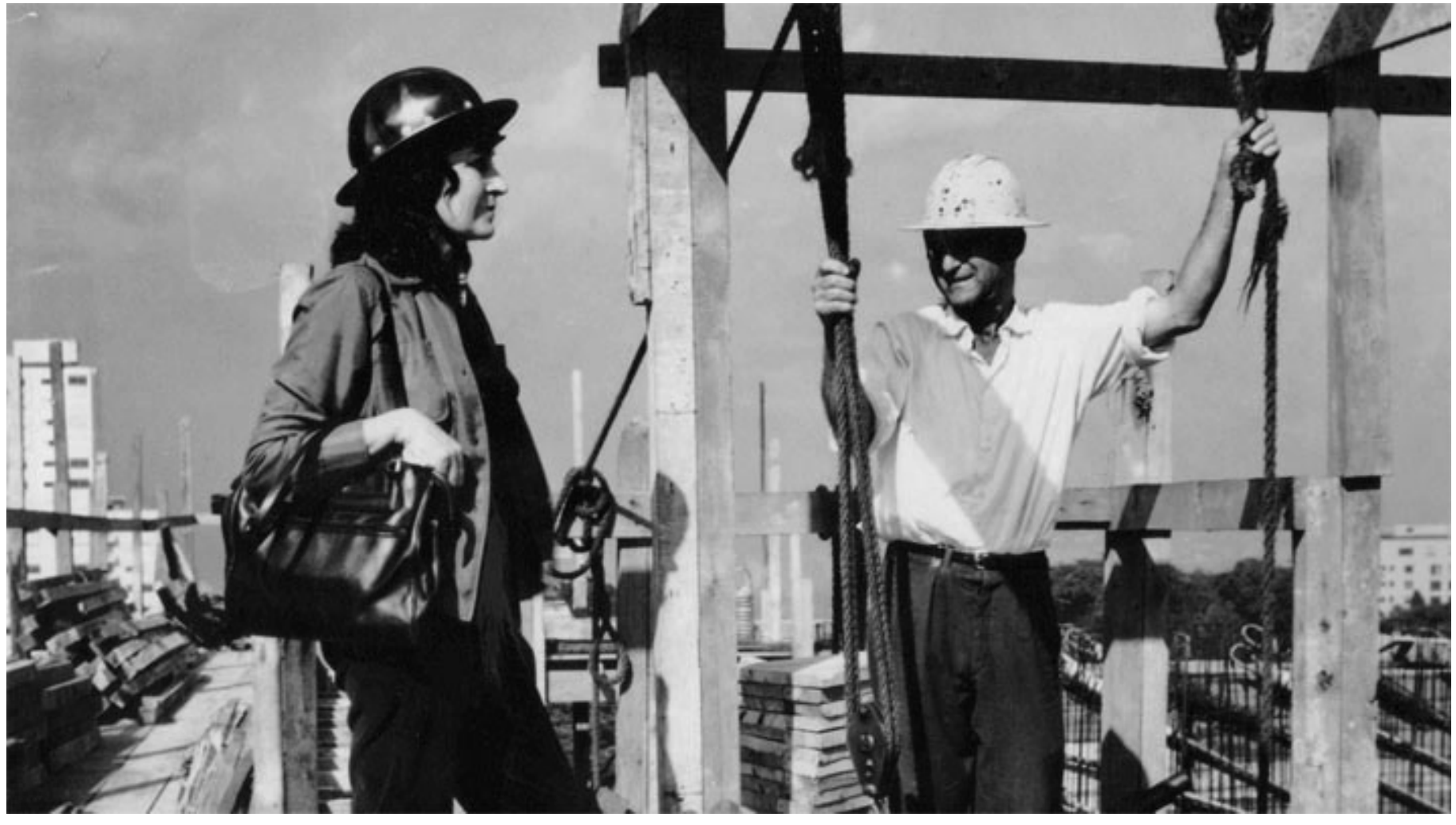

Lina acompanhando a obra. Fonte: FERRAZ, M. (1997). S/p.

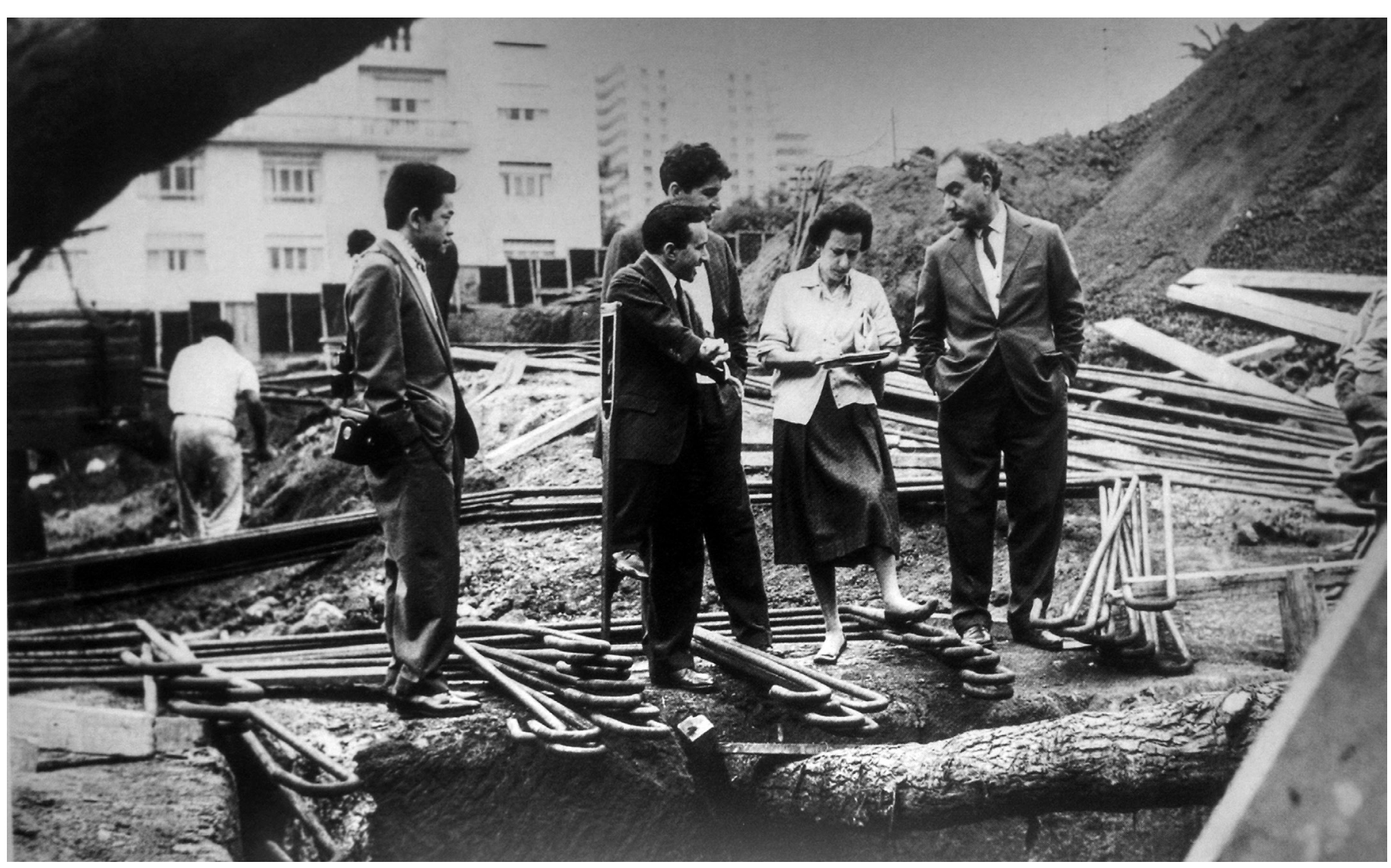

Pietro Maria Bardi atende ao jornalistas no canteiro de obras. Fonte: GOUVÊA, R. (2008). P. 69. radas lá escolas de gravura, pintura, design industrial, escultura, ecologia, fotografia, cinema, jardinagem, teatro, dança e moda, em continuidade com o que já acontecia na sede anterior.

A simplicidade de acabamento do projeto do MASP foi tema de questionamentos no circuito cultural naquele momento. Apesar de o edifício da FAU-USP, de Vilanova Artigas, e do MAM-RJ, de Affonso Eduardo Reidy, estarem sendo construídos na mesma época e também utilizarem a limpeza, o minimalismo e o concreto aparente como linguagem, essa estética ainda estava em vias iniciais de ser apropriada pelo sistema.

[...] Lina adotou uma estética despida de acabamentos industriais (à maneira de Vilanova Artigas), mas também como ato de resistência ao apagamento das marcas dos operários (num sentido próximo ao que defenderam os arquitetos Flavio Império, Rodrigo Lefévre e Sergio Ferro). ${ }^{30}$

O canteiro de obras era para Lina uma extensão do escritório de projeto e, lá - em conjunto com operários, engenheiros e outros arquitetos - Lina desenhava e redesenhava o futuro do MASP. Erros e problemas técnicos eram comumente incorporados ao projeto, e soluções eram encontradas à medida que problemas surgiam, in loco.

O reconhecimento da origem mítica do MASP reside em sua força concisa, simples e direta, ao mesmo tempo lírica e épica, sugerindo múltiplas metáforas. Reside também na condição do terreno sobrevivente em um espaço densificado, resquício miraculoso e absurdo à logica do capitalismo: um espaço para nada. Mas a origem mítica reside sobretudo na condição que nós mesmos criamos em nossa mente, acolhendo-a sem concessões. No fundo, o que menos desejamos é desvelar o mistério, por isso o aceitamos. E o nascimento mágico da arquitetura do MASP é, sem dúvida, inseparável de sua própria existência.”

\footnotetext{
MiYOSH, A. Arquitetura em Suspensão: o edificio do Museu de Arte de São Paulo. São Paulo: Armazém do Ipê, 2011.
}

31 Alex Myioshi - pg 20/2 
Figueiredo Ferraz foi o engenheiro por trás da viabilização desse projeto que à época parecia tecnicamente inviável e utópico. Convidado por Lina Bo Bardi para participar desse desafio, Ferraz viu a possibilidade de incorporar técnica à arte e alcançar um resultado estético único. Para esse projeto, ele desenvolveu uma maneira nova de protender o concreto para vencer o gigantesco vão, que foi denominada "patente Ferraz". O engenheiro também foi fundamental por conta de a arquiteta ter permanecido até 1968 entre idas e vindas de Salvador a São Paulo. Ele era o corpo presente durante todo o processo.

A decisão pelo total envidraçamento do edifício, tão coerente com o discurso da democratização e da conexão entre espaços pode ser vista também como oriundas do acompanhamento de outros projetos que eram desenvolvidos pelo mundo naquele momento, e que também utilizavam esse material como discurso moderno tais como o Museu de Belas Artes de Houston e Nova Galeria de Berlim, ambos de Mies van der Rohe. Como aponta Alex Miyoshi, essas eram "referências estimulantes à radical transformação do museu tropical”. ${ }^{32}$

Pietro Maria Bardi acompanhou com apreensão a decisão de Lina por trocar as antes planejadas iluminações zenitais pelas fachadas de vidro, já que a princípio isso poderia afetar a segurança das pinturas, que passariam a receber luz natural direta, porém se viu compelido a abraçar o material após extensa pesquisa sobre os avanços da indústria vidraceira italiana, em texto publicado em 1930.

“(...) O vidro é hoje um dos elementos preponderantes da arquitetura moderna: ele tem um papel predominante [...] e a conquista do ar e da luz obtida na nossa época - por meio da nova arquitetura - é principalmente mérito [...das suas novas possibilidades]. ${ }^{33}$
Para além de questões técnicas que ele enxerga como já muito melhores do que em tempos passados, ele continua:

"No fundo, tudo é lógico na evolução do progresso humano. Somente hoje, que o trabalho é um direito, o povo é verdadeiramente povo; somente hoje, portanto, há o problema integral da vida do povo. Mas sendo a luz a primeira necessidade da vida, somente a atual poderia - e deveria - ser a época do vidro, triunfo de um mistério na idade mais científica do gênero humano"

Com isso, o conceito de transparência abraça o MASP e irá também ser a base do discurso construído pela museografia que Lina está desenvolvendo para a Pinacoteca do museu.

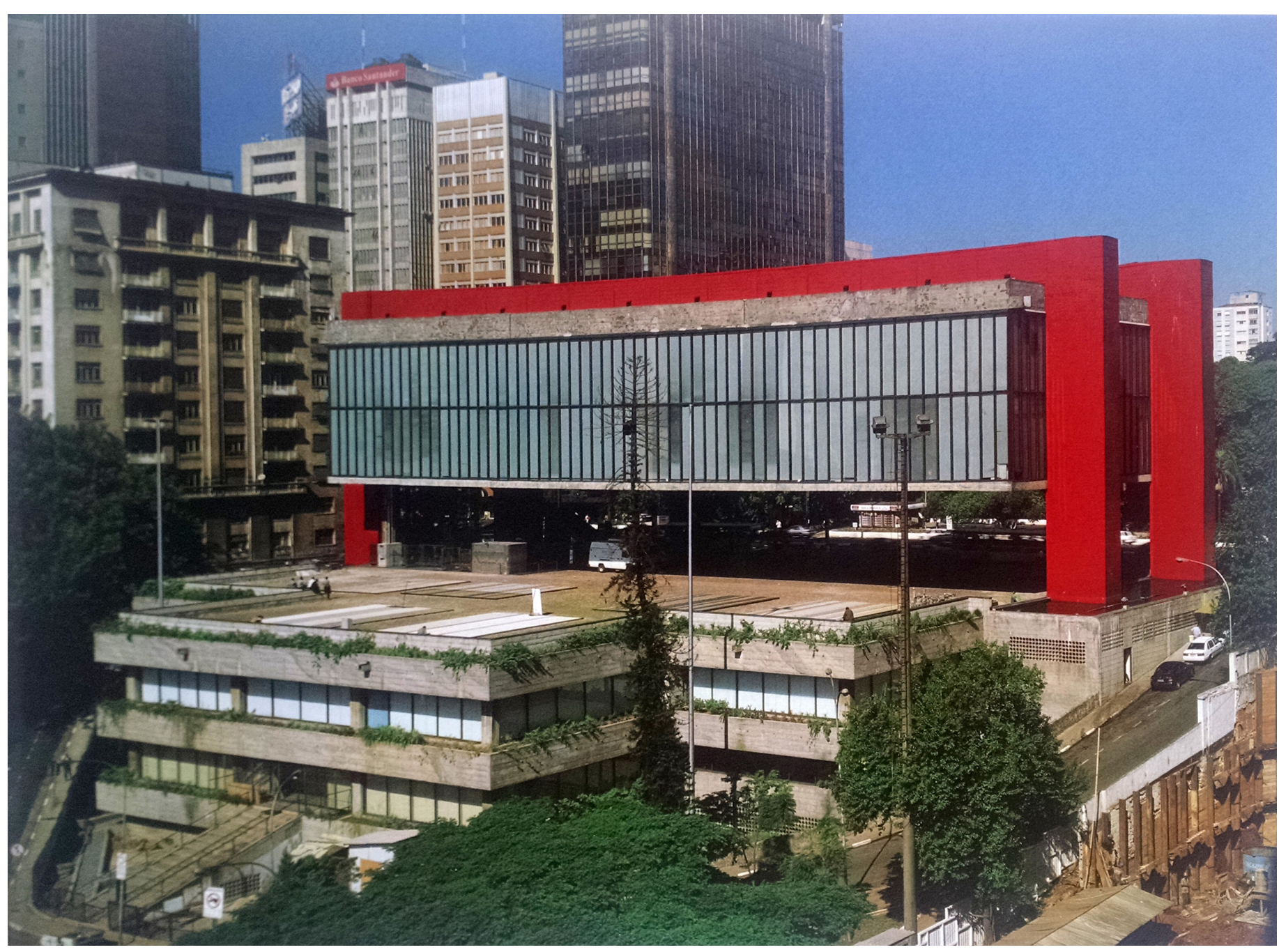

Vista do Masp a partir do Vale do Anhangabaú. Fonte: OLIVEIRA, O. (2006). P. 63. 
saber respeitar essa espécie de altar onde a obra estava pendurada uma forma de ritual de respeito e admiração sempre esteve envolvido $\mathrm{n}$ princípio desse ambiente imaculado. O simples ato de escolher uma obra para estar na parede de um espaço museológico com essa configuração eleva seu status e transforma a maneira como o visitante irá vivenciar a obra. $\mathrm{E}$ isso dá poder para quem faz as escolhas.

O cubo branco opera sob o pretexto de que sua aparente invisibilidade permite que a obra de arte fale melhor por si, ele parece em branco, inocente, inespecífico, insignificante. Em última análise, o que faz de um cubo branco um cubo branco é que, em nossa experiência nele, ideologia e forma se encontram, e tudo isso sem que nos apercebamos. ${ }^{36}$

A ideologia embutida na neutralidade do espaço expositivo está inevitavelmente ligada a um discurso de poder. A forma como o público vai se relacionar com as obras no espaço, mesmo que não perceba, é determinada pela sua consciente configuração. Não é de se estranhar que, em 1937, alguns anos após a criação da ideia de cubo branco, o ditador Adolph Hitler tenha decidido adotar o modelo na Haus der Kunst, em Munique, o primeiro projeto arquitetônico nazista depois de ele ter tomado o poder.

O conceito do cubo branco envolve a ideia de controle total, uma situação espacial e expositiva que não oferece maiores possibilidades de reflexão.

Hoje, porém, instituições museológicas pelo mundo vem tentando mudar essa linguagem "ditatorial", criando modelos que estabelecem narrativas não convencionais e que empoderam o público, colocando -o numa situação de agente dentro das escolhas de como se relacionar com cada obra. O museu TATE Britain, em Londres, é um dos que promovem interessantes experiências na forma de mostrar, de modo permanente, seu acervo. Em 2013, foi inaugurada uma inovadora cronologia da coleção, organizada não por escolas, mas, estritamente, pela data em que cada pintura foi realizada. A escolha, que parece simples, gera uma desconstrução total da ideia de linearidade e estilos que temos construída em razão da forma como fomos educados.

É claro que a cronologia é uma maneira muito tradicional de organizar um museu. Mas esta é uma cronologia mais neutra do que é habitual, e, nesse sentido, é mais radical. Pedi aos curadores para esquecer os movimentos históricos e escolas da arte. [A nova linha do tempo] não agrupa 'Hogarth e o nascimento da pintura britânica', ou 'Gainsborough e os anos dourados'. Agrupa o que os artistas estavam fazendo em 1610, ou o que eles estavam fazendo em 1910. Ela reúne as coisas que normalmente não seriam pendurados juntas e mostra que em tempo real, ao contrário do tempo museológico, as coisas se movem de maneiras mais imprevisíveis e elásticas do que a história da arte tende a apresentar. O resultado é que você tem obras tardias de alguns artistas se acotovelando com as primeiras obras de outros, até os dias de hoje, com por exemplo Bridget Riley e Leon Kossoff ao lado de Anya Gallaccio e Gary Hume.37

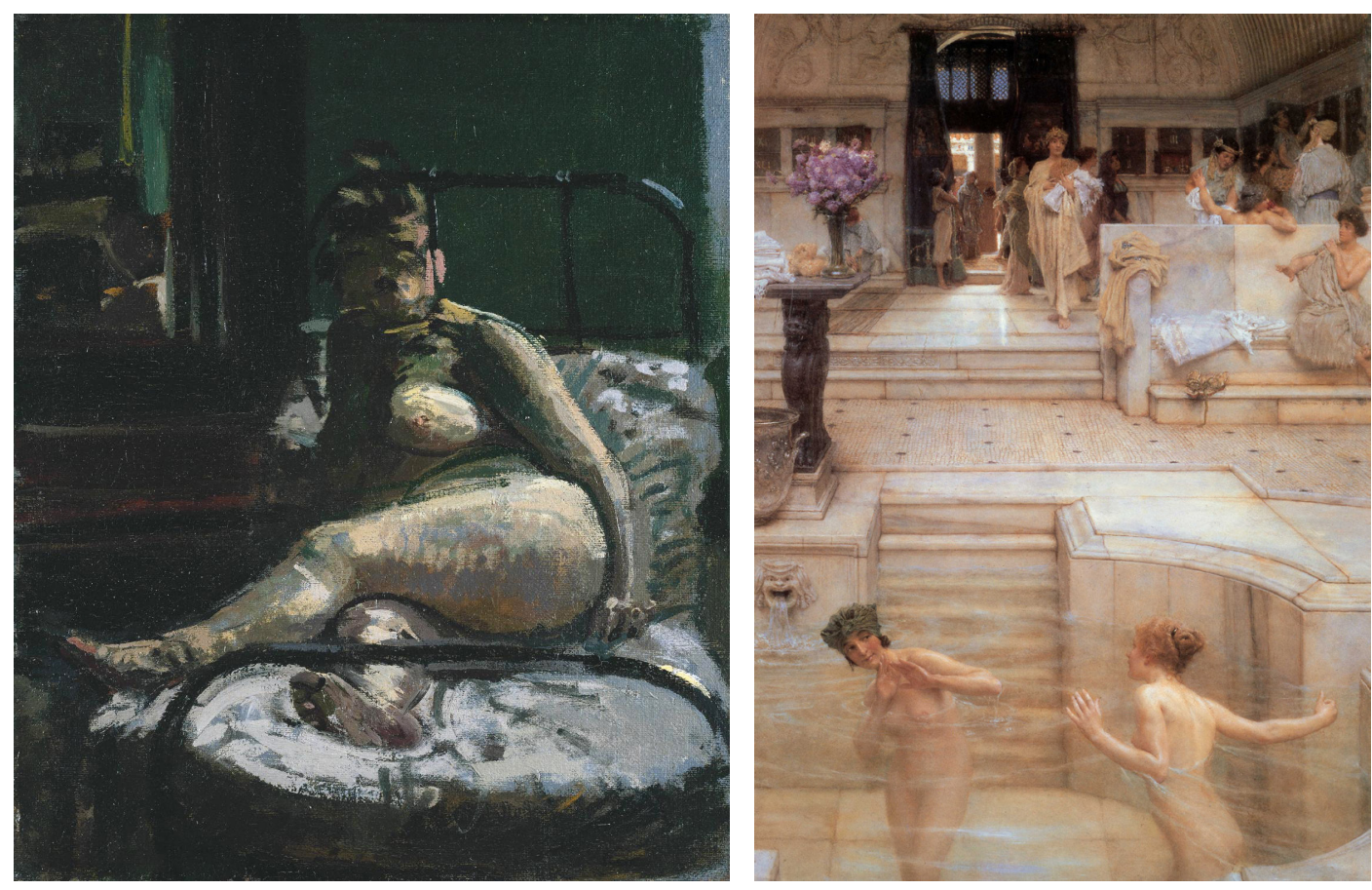

"La Hollandaise" de Walter Richard Sickert e "A Favourite Custom", de Lawrence AlmaTadema, agora lado a lado na nova montagem da pinacoteca da TATE Britain. Imagem:

37 http://www.theguardian.com/artanddesign/2013/may/03/tate-britain-on-move-rehang - tradução livre. 
A proposta claramente visa quebrar com a expectativa consolidada pela maioria dos museus de se estabelecer como um grande livro da história oficial da arte. Essa atitude, apesar de não depender da criação de um novo modo de expor, desloca o público para uma compreensão libertadora da produção dos artistas, menos hierarquizada, mais humana.

O Louvre, em Paris, também é uma das instituições que tateia novas maneiras de lidar com a exposição permanente de seu acervo. Em dezembro de 2013, inaugurou em sua unidade Louvre-Lens a exposição semipermanente intitulada "Uma Apresentação Transversal: um novo olhar sobre as coleções do Louvre”, com obras-primas do acervo de sua sede. A ideia, em grande parte, lembra os princípios de desierarquização propostos por Lina Bo Bardi e Pietro Maria Bardi: escolheu-se montar essa grande exposição em uma única sala, com a justificativa de que isso permitiria que obras de arte produzidas por diferentes civilizações e culturas - mas concebidas no mesmo ponto da história - fossem justapostas. Segundo os curadores, isso liberta o público das restrições do museu do Louvre, em Paris, onde as coleções são sempre apresentadas por departamento, não permitindo o diálogo entre obras de arte do mesmo período. Nessa nova forma de expor a coleção, visitantes poderão ver, por exemplo, obras-primas da Grécia clássica lado a lado com peças do império persa. Essa proposta traz em sua base o desejo de criar uma nova forma de entender a história da arte e da humanidade, que oferece ao público as ferramentas para estabelecer essas conexões.

É também parte do discurso da instituição a ideia de inclusão de um público não familiarizado com museus. A abertura dessa unidade em Lens tem como baselevar exposições para perto de populações desprivilegiadas de uma forma generosa e não opressora.

A maneira como os museus consolidam seus espaços expositivos - arquitetura e forma de apresentar as obras - é o que define o discurso ideológico de uma instituição.
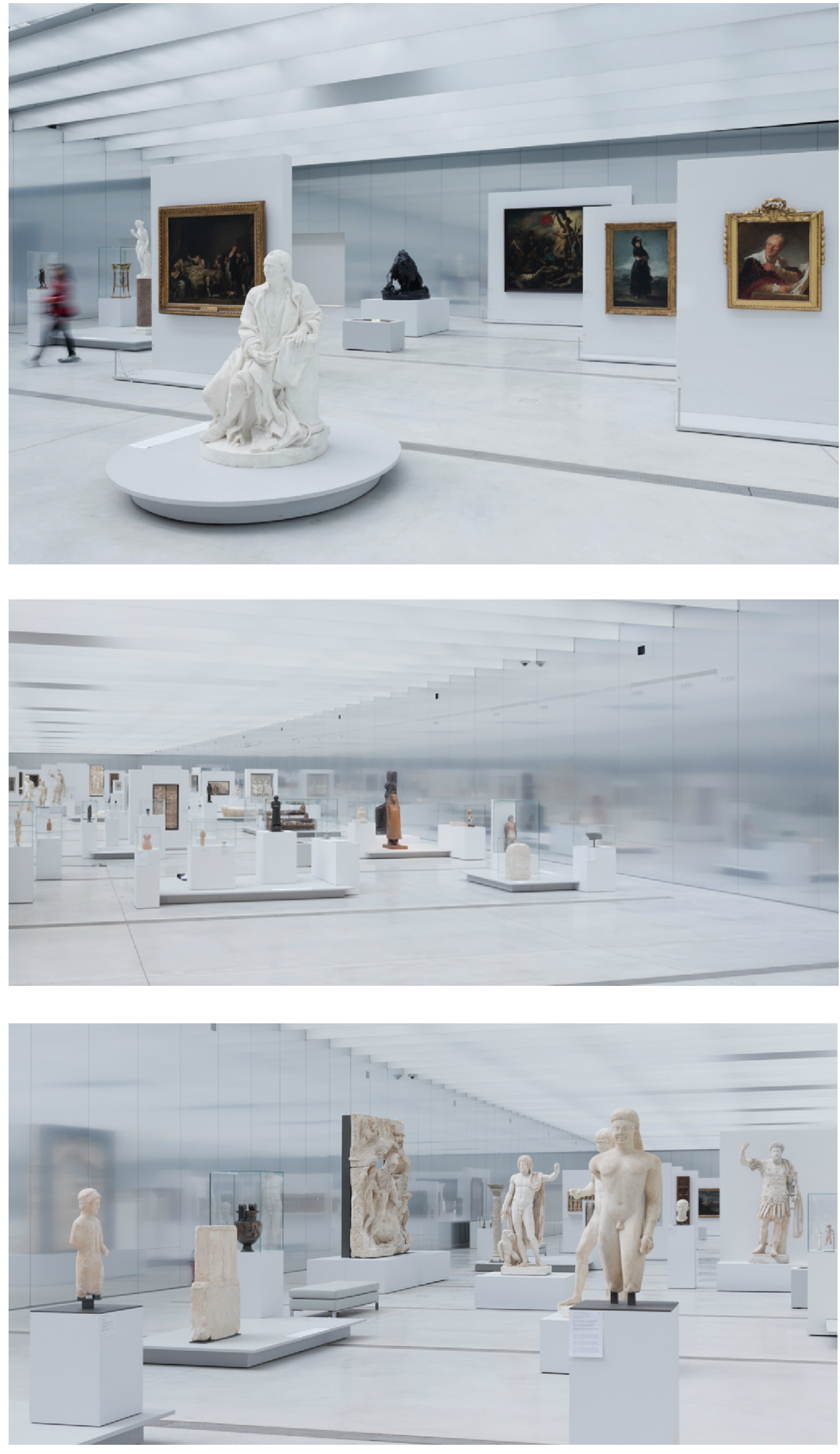

Vista da exposição. Musée du Louvre-Lens I @ MOSBACH PAYSAGISTE / Catherine Mosbach 
[...] Num momento quando a arte permanece como um dos poucos modos de resistir, criticamente, a transformações hegemônicas (...), as formas de exposição precisam ainda mais urgentemente ser meios inteligentes, sensíveis e apropriados para tornar a arte pública. (...) Obras de arte, por mais que sejam elementos na construção do significado de uma exposição e ainda, dialeticamente, sejam submetidas à sua encenação, também, de fato, articulam posições estéticas e intelectuais e definem modalidades de experiência que resistem às molduras temáticas ou estruturais nas quais são colocadas. (...). A maneira pela qual uma seleção de obras de arte, um contexto tectônico, e outros acompanhamentos temáticos ou discursivos coalescem em uma determinada forma está no cerne de como uma exposição se expõe. Isso, afinal, é o que distingue uma exposição de, digamos, um ensaio ilustrado: a articulação de um espaço físico específico através do qual as relações entre espectadores e objetos, entre um objeto e outros, e entre objetos, espectadores e seu contexto específico de exposição são encenadas. ${ }^{38}$

Dentro disso, podemos olhar para o MASP como um projeto que adiantou em muito discussões que hoje são a pauta das instituições museológicas pelo mundo. O projeto de Lina, porém, foi feito em um momento histórico com limitadas possibilidades para lidar com questões técnicas, o que resultou numa coerência de discurso ideológico, mas uma situação real que colocava a coleção em risco. Porém, não há dúvidas de que esse "adiantamento histórico" de Lina é o que faz com que o MASP e os cavaletes de cristal estejam, constantemente, em pauta quando a discussão envolve as perguntas: como apresentar arte para o público hoje? E quem é esse público? Quais são suas expectativas ao visitar um museu? É fato que grande parte do público frequentador assíduo de museus, e inseridos no circuito cultural tradicional, irá adotar um discurso conservador frente a mudanças no status quo das instituições museológicas. Para eles, a

38 FILIPOVIC, Elena. The Global White Cube, Disponivel em OnCurating org - http:I/ www.on-curating.org/index.php/issue-22-43/the-global-white-cube.htmlt.VOO6E1Xwww.on-curating.org/
F8ww. Tradução livre. linguagem já é consolidada, natural e não há sentido em desestabilizar essa situação. No entanto, para toda uma enorme parcela de potenciais visitantes, o olhar enciclopédico e sagrado dos museus é algo que repele e desestimula. É um universo distante demais e sem pontes que facilitem a travessia. A generosidade das novas formas de pensar os museus hoje, centro do pensamento de Lina Bo Bardi, está ligada a um modo menos elitista e exclusivista de apresentar arte para o público.

Além de aspectos técnicos que defendiam a retirada dos cavaletes, havia uma outra questão que também inquietava a administração do museu e outros críticos externos: a contraditória organização do acervo no espaço da pinacoteca e a falta de um olhar em sintonia com narrativas propostas por instituições internacionais.

Pode-se notar em vários textos de Lina que a arquiteta foi, cada vez mais, se alinhando à arte moderna e popular em detrimento da arte clássica. Essa predileção a encaminhava para uma situação de contradição: a coleção do MASP, apesar de contar com grande acervo de obras populares, de arte africana e indígena, era predominantemente formada por cânones da pintura. Contraditoriamente, ao definirem a disposição das obras, Lina, junto com Pietro Maria Bardi (assumidamente mais próximo às artes clássicas) acabaram optando por organizar a Pinacoteca em algo muito próximo a uma ordem cronológica. É difícil encontrar textos que falem especificamente dessa decisão, mas o fato é que este dado é com frequência utilizado como evidência da falta de rigor de Lina Bo Bardi na elaboração desse projeto expográfico - um discurso pungente de dessacralização e quebra de narrativas supostamente abafado por uma escolha final pela tradição.

Opondo-se à validade dessa crítica, a arquiteta e pesquisadora Olivia de Oliveira comentou em entrevista realizada em janeiro de 2015 para essa dissertação sobre sua experiência vivencial do espaço da Pinacoteca: 
Quando o elevador abria a porta [no andar da pinacoteca] você via aquilo na sua frente: os quadros todos, um atrás do outro. Era um choque. Algo que nunca vimos em lugar algum. Era muito impressionante. As pessoas esquecem como era forte essa imagem de chegar e se deparar com tudo lá, na sua frente, um mundo de quadros como se fossem pessoas olhando pra você. Todas elas olhando pra você.

E sobre o fato de muitos criticarem a escolha por haver uma certa organização cronológica na distribuição das peças no espaço, avalia:

Organizado ou não [em ordem cronológica], of fato é que você tinha tudo junto - todas as épocas, tudo em transparência, tudo superposto, acontecendo aqui e agora, num só lugar, num só instante.

De fato, um aspecto marcante vivenciado no processo de desenvolvimento dessa pesquisa foi conversar sobre o tema com as mais variadas pessoas, das mais distintas formações, e notar que, sem nem mesmo termos que pedir um depoimento sobre que tipo de lembrança carregavam daquela museografia, todos se manifestavam sobre como era forte e desconcertante mergulhar naquela Pinacoteca. Muitos se recordavam inclusive de como gostavam de percorrer aquele mar de telas, quais pinturas gostavam de ver primeiro, como se relacionavam com aquele espaço. Eram curadorias pessoais, exatamente como Lina desejava, que mesmo após quase vinte anos permanecem vivas na memória de quem teve a chance de vivenciar o museu.
3.2 O Cavalete de Cristal:

design de uma nova forma de ver e entender a arte

Foi o escritor francês André Malraux que, em 1947, em seu livro "O Museu Imaginário", desenvolveu o conceito de "museu sem paredes" - referindo-se a um movimento novo que ele começava a identificar em alguns museus no século XIX, que juntavam os mais variados perfis de produção, de todos os tempos e lugares, num mesmo espaço. Ele via nessa nova e crescente tendência a possibilidade de um movimento libertador, por ser muito mais potente e democrática do que a proposta pelos museus tradicionais, que dividiam e segregavam suas peças entre paredes - conceituais ou físicas. A partir dessas ideias, desenvolveu seu Museu Imaginário. Malraux entende que o papel de instituições museológicas é muito maior do que simplesmente dispor coleções para que o público tenha acesso. A forma como esse público se relaciona com o acervo depende, fundamentalmente, de decisões curatoriais sobre como apresentá-las no espaço.

Lina olha para questão próximas a essas ao tomar decisões sobre como irá apresentar a coleção do MASP em sua nova e definitiva pinacoteca.

Lina cria um museu sem paredes, sem barreiras e fronteiras, no qual as obras de arte, como imagens flutuantes no grande salão, parecem traduzir a riqueza e amplidão das inúmeras obras artísticas guardadas nas nossas mentes. Tendo como base de organização das obras de arte o predomínio da atemporalidade, sem seleção e definição de prioridades, tal organização das obras não direciona o olhar do observador para nenhuma obra privilegiada, muito pelo contrário. Deixando-o livre para suas escolhas, oferecelhe as obras apenas como imagens. Imagens que, sem identificação imediata, o remetem às outras imagens ali presentes, bem como a tantas outras retidas na memória; imagens cujas molduras, entalhadas e douradas, além de introduzirem um sentido de luxo passado, parecem buscar mais uma vez o momento original da obra, a representação da cena no passado, no tempo de quem a pintou, 
Nesse sentido, sua decisão sobre como apresentar a coleção do MASP no espaço da Pinacoteca é de grande coerência: a proposta curatorial é oferecer ao público um espaço libertário, transgressor, antiaurático, onde o tempo não é cronológico e, sim, vivencial. Nesse novo espaço, projetado a partir de todos os princípios que envolviam o pensamento do casal Bardi, nasce uma forma de expor que ainda hoje é tida como única, ousada e polêmica.

É difícil imaginar uma solução mais minimalista em termos materiais e de desenho e, ainda assim, mais ousada em termos expográficos e de rompimento com regras clássicas de museografia que o cavalete de cristal concebido por Lina Bo Bardi para o MASP. Um objeto que dá continuidade à arquitetura do edifício, de concreto e vidro. Uma grande lâmina vertical de vidro incrustrada num cubo sólido de cimento e estabilizada por uma cunha de madeira. Um aparato que quase se anula frente à sua própria invisibilidade, mas que cria uma presença transformadora ao ser colocado em uso. Uma obra que, ao ser pendurada em um pano vertical de vidro, flutua sobre sua superfície - nas palavras de Lina Bo: "porque é um cavalete, e um quadro nasce no ar, num cavalete" 40.

Alex Miyoshi, em análise a um texto escrito por Bo Bardi, observa que o cavalete seria "[...] um elemento que integra duas peças modernas e industriais - uma lâmina de vidro e um bloco de concreto -, unidas por uma cunha de madeira, peça "artesanal”, junção quente de duas matérias frias”. ${ }^{41}$ 39 http://www.docomomo.org.br/seminario\%209\%20pdfs/169_M27_RM-LinaBoBar-
diEoMuseulmaginario-ART_suely_puppi.pdf

40 BARDI, Lina Bo - Explicações sobre o Museu de Arte in jornal "O Estado de São Paulo", 5/abr/1970 - Arquivo Instituto Lina Bo e P M Bardi.

41 MIYOSHI, Alexander Gaiotto. Arquitetura em Suspensão - O edifício do Museu de

Arte de São Paulo. São Paulo: Armazém do lpê, 2011.

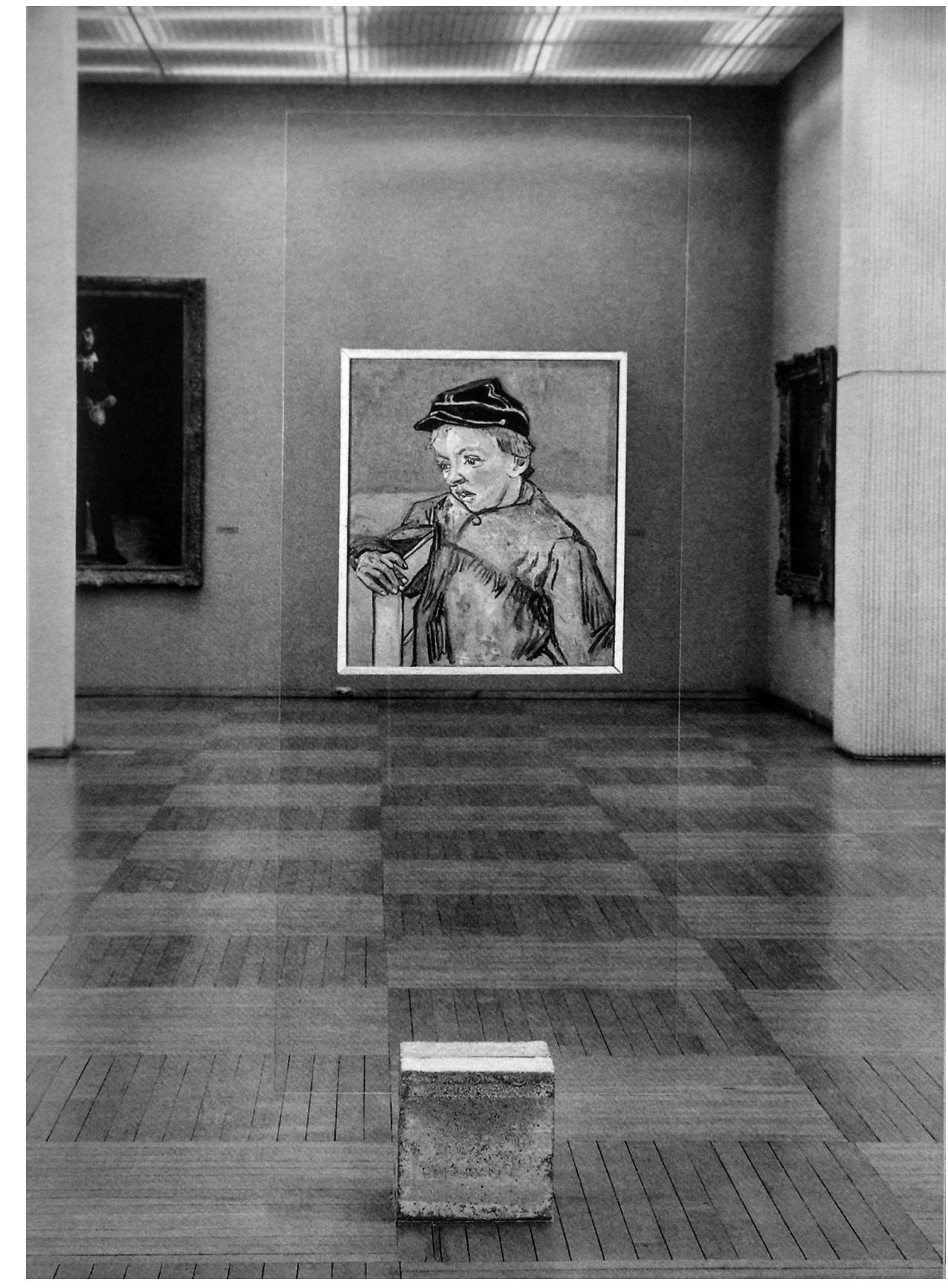

Ainda no espaço da Rua Sete de Abril, foto da primeira vez que é apresentada a solução para a montagem das obras para o novo MASP. Fonte: LATORRACA, G. (2014) p. 117. 
Olivia de Oliveira também comenta sobre a coerência construtiva do cavalete:

"Os suportes dos quadros da pinacoteca do MASP são como uma maquete do edificio: uma parte transparente, aérea, que flutua, e a outra opaca, não-vista, submersa em uma base de concreto." (OLIVEIRA, 2006, p. 335)

E sobre o uso do vidro, completa:

"A transparência do vidro traz a cidade para dentro do edifício e dali o espectador a apreende, tornando-se ele mesmo ator dessa realidade. Ele se mistura aos quadros que, por sua vez, misturam-se com a paisagem, com a cidade e com os transeuntes." (OLIVEIRA, 2006, p. 323)

A grande quantidade de cavaletes distribuída pelo espaço do museu, criando um mar de pinturas nesse ambiente de flutuação, dá força a essa proposta expográfica. A partir desse momento, um quadro já não pode ser visto de maneira totalmente individualizada, muito menos como parte de uma hierarquia histórica ou temporal pré-definida. A transparência dos cavaletes faz com que todas as obras ocupem o mesmo espaço visual simultaneamente, sobrepondo-se e criando a possibilidade de novas histórias e percursos que se definem, predominantemente, a partir de decisões dos visitantes e não de uma curadoria rígida - orientada, por exemplo, por linhas do tempo ou de escolas. A curadoria, assim, é na verdade produzida por cada um que visita o espaço e o percorre a partir do interesse que sente por cada obra. Essa proposição de Lina coloca o público frente ao acervo não como leigos ou crianças, mas, sim, como parceiros, como pessoas que podem tomar suas próprias decisões sobre como desbravar e compreender aquele território cultural desarranjado "quase propositadamente no sentido de produzir um choque que desperte reações de curiosidade e de investigação" [Habitat (1): 17, 1950]

Suspensos nos cavaletes de vidro, os quadros deixavam as paredes para virem procurar a companhia do público. Eles se misturavam ao público e, por transparência, víamos uma fusão e superposição de acontecimentos. Aqui quadros e visitantes estavam liberados de todas as balizas de épocas e leituras pré-definidas. [...] Os cavaletes são importantes não por sua aparência formal, mas porque eles abrem uma nova maneira de relacionar visitantes e quadros. Pois tal como na obra dos mestres da arquitetura moderna e das primeiras vanguardas, a ruptura formal aqui apoia-se na superação da percepção habitual e rotineira do espectador e jamais num formalismo inconsequente. ${ }^{42}$ 
$=0$ 


\subsection{Frente e verso:}

discurso curatorial transformado em display

Além do contato visual com a obra, ao desenhar esse aparato, Lina tinha em vista a necessidade de criar uma área para a disposição dos conteúdos educativos, dando continuidade ao seu projeto desenvolvido na sede anterior do MASP, na Sete de Abril - prosseguindo com a intenção de não orientar o público a se relacionar com uma obra simplesmente porque sua legenda anunciava um Picasso ou Rembrandt. Como esse display nada mais é do que uma lâmina de vidro solta no espaço, possui naturalmente duas faces passíveis de uso. A partir dessa divisão simples, a arquiteta determinou funções bem definidas: a frente - ou a face que está voltada para a direção da entrada principal do acervo - recebe a obra, sem qualquer outro tipo de conteúdo periférico. No verso, encontra-se o que ela chamou de "painel didático", onde o público poderia encontrar informações sobre o artista, o contexto de produção da obra ou qualquer outra informação que a equipe do museu julgasse pertinente e enriquecedora. Era de certa forma uma maneira de fundir em um único espaço os princípios presentes nas exposições didáticas e na Pinacoteca da Sete de Abril.

A partir da intenção de educar o público que se formava, seus textos localizavam cada obra em seu momento histórico e, pela relação com o momento em que foi produzida, revelavam que aquilo era produto de uma determinada forma específica de entender o mundo artista que pertenceu a um determinado momento. Sobre esse recurso, Gulherme Wisnik comenta:

Cada vez mais, qualquer pessoa, mesmo nós [que trabalhamos com cultura], é vitima disso: quando você vai num museu você quase sempre está um pouco com pressa, não está assim completamente entregue, e aí a primeira coisa que você faz é ler a legenda. É difí-
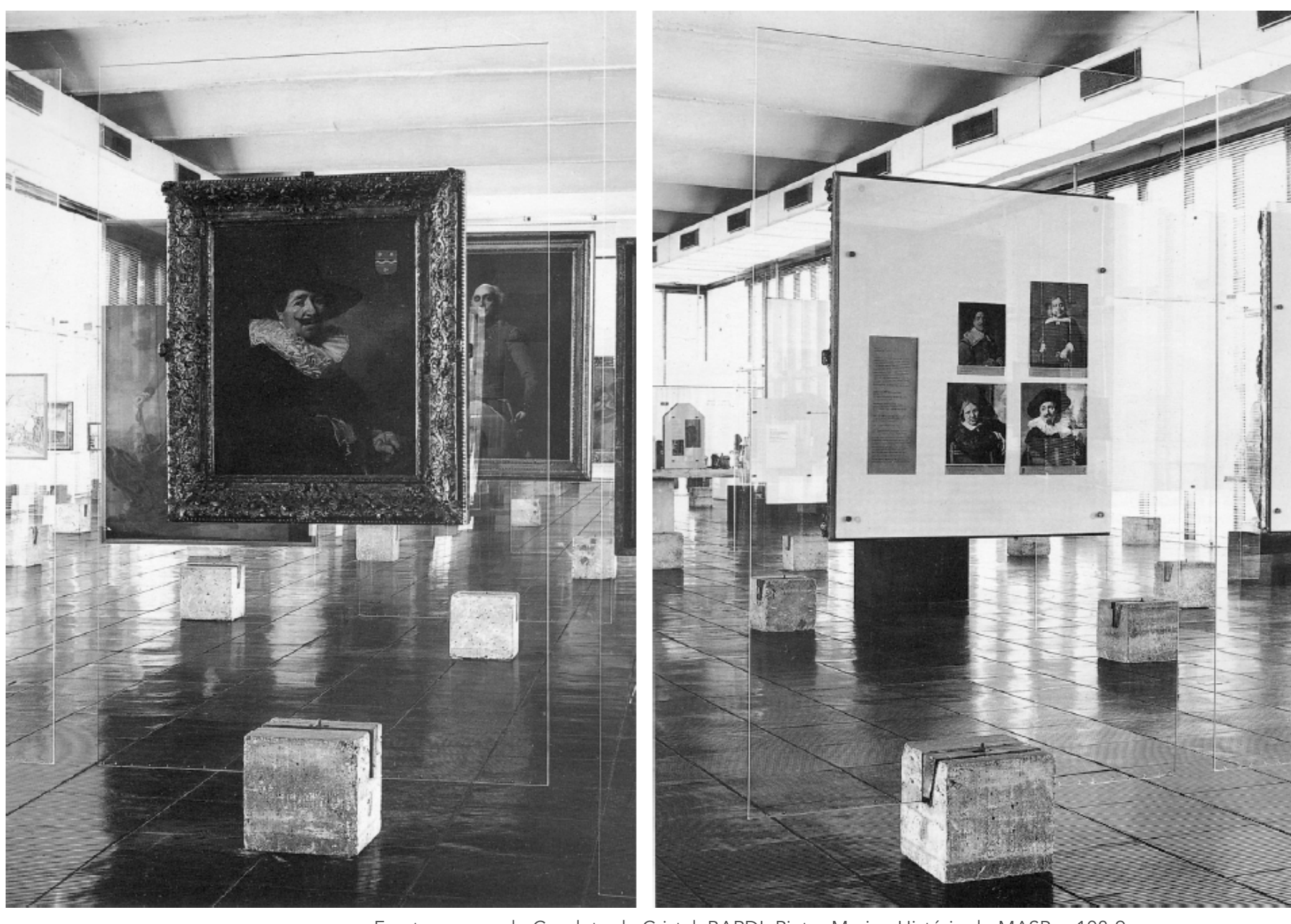

Frente e verso do Cavalete de Cristal. BARDI, Pietro Maria - História do MASP, p 108-9 
cil escapar disso. E a Lina ajudava de alguma forma a evitar esse comportamento.

O curador e crítico Roger Buergel afirma, em texto chamado "Esta exposição é uma acusação - A Gramática do display de acordo com Lina Bo Bardi” que uma das coisas mais interessantes que a arquiteta consegue com a museografia do MAP é fazer com que o público deixe de estar submetido a uma curadoria, qualquer que seja. O público não é visto como ignorante, como alguém que provavelmente não tem as ferramentas intelectuais necessárias para lidar com o conteúdo apresentado. Na situaçnao proposta por ela, o visitante passa a ser visto como um parceiro a partir da criação de uma situação espacial que não permite passividade. Sobre isso, Gulherme Wisnik, em conversa em agosto de 2014, complementa dizendo que essa atitude é reconhecível em vários outros momentos da obra da arquiteta:

[essa não-passividade] está de alguma forma presente nas cadeiras do auditório do SESC Pompeia também. Lina fala inclusive que isso é uma concepção Brechtiana de teatro, que a pessoa não pode ficar com sono, deve permanecer sempre engajada, ativa. É o não -passivo. $E$ isso de fato dá mais independência e autonomia para o público. Ele toma suas próprias decisões. Ele não é infantilizado.

O dramaturgo e poeta alemão Bertold Brecht, criador do que hoje chamamos de teatro moderno, transformou o teatro ao decidir romper com os limites entre palco e público, o que revolucionou a teoria e a prática da encenação, aproximou o teatro de questões sociais. Para Brecht, o público era parte da encenação e o teatro só acontecia se audiência e atores estivessem em sintonia nas ações. Poremos, de certa forma, aproximar os partidos da museografia da pinacoteca do MASP com esse preceito brechtiano: a exposição não existe, ou não faz sentido, se o público não se engaja.

Voltando ao período que a arquiteta passou na Bahia, observamos elementos que ajudam a reforçar o que foi apontado há pouco como um casamento de precisão entre display e arquitetura, entre mo- derno e popular, realizado por Lina Bo no MASP. A arquiteta explica que na Bahia aprendeu "a lição da experiência popular, não como romantismo folclórico, mas como experiência de simplificação" (FERRAZ, 1993, p. 100).

Sem dúvida, a simplificação está em pauta tanto no design do cavalete como no projeto arquitetônico do museu. Especificamente em relação à criação do display, Cristina Garcia Ortega indica em texto sobre o período de Lina em Salvador que a organização das feiras populares motivaram a arquiteta a pensar espaços radicalmente destituídos de narrativa e, ainda assim, altamente potentes no sentido de despertar interesse e curiosidade.

Apesar da organização e equidistância entre os cavaletes, sua ambientação experimenta as mesmas condições dos arranjos físicos encontrados nas feiras populares do Brasil afora, onde nos deparamos com situações espaciais restritivas espacialmente, mas ao mesmo tempo, tem-se a impressão de que os produtos encontrados nestas feiras vão ao encontro do público, assim como as obras suspensas como que espargindo a essência da arte no ar - pareciam assediar os visitantes. Da mesma forma que muitas vezes nos deparamos com os próprios artesãos desenvolvendo suas peças em meio às feiras de artesanato, os cavaletes remetem ao estado de criação da obra, aos momentos de concepção, fazendo o artista ausente se aproximar do interlocutor, numa simbiose entre o observador e o observado. ${ }^{43}$

As feiras populares já foram assunto para a arquiteta em outros momentos, especialmente durante o período em que esteve na direção do Solar do Unhão, quando desenvolveu uma exposição chamada "Nordeste" (Solar do Unhão, 1963).

De acordo com sua própria definição, a exposição teve uma visão antropológica em vez de estética sobre os artefatos populares criados no Nordeste brasileiro. A exposição consistia em uma abundân-

43 http://www.docomomobahia.org/linabobardi_50/4.pdf 

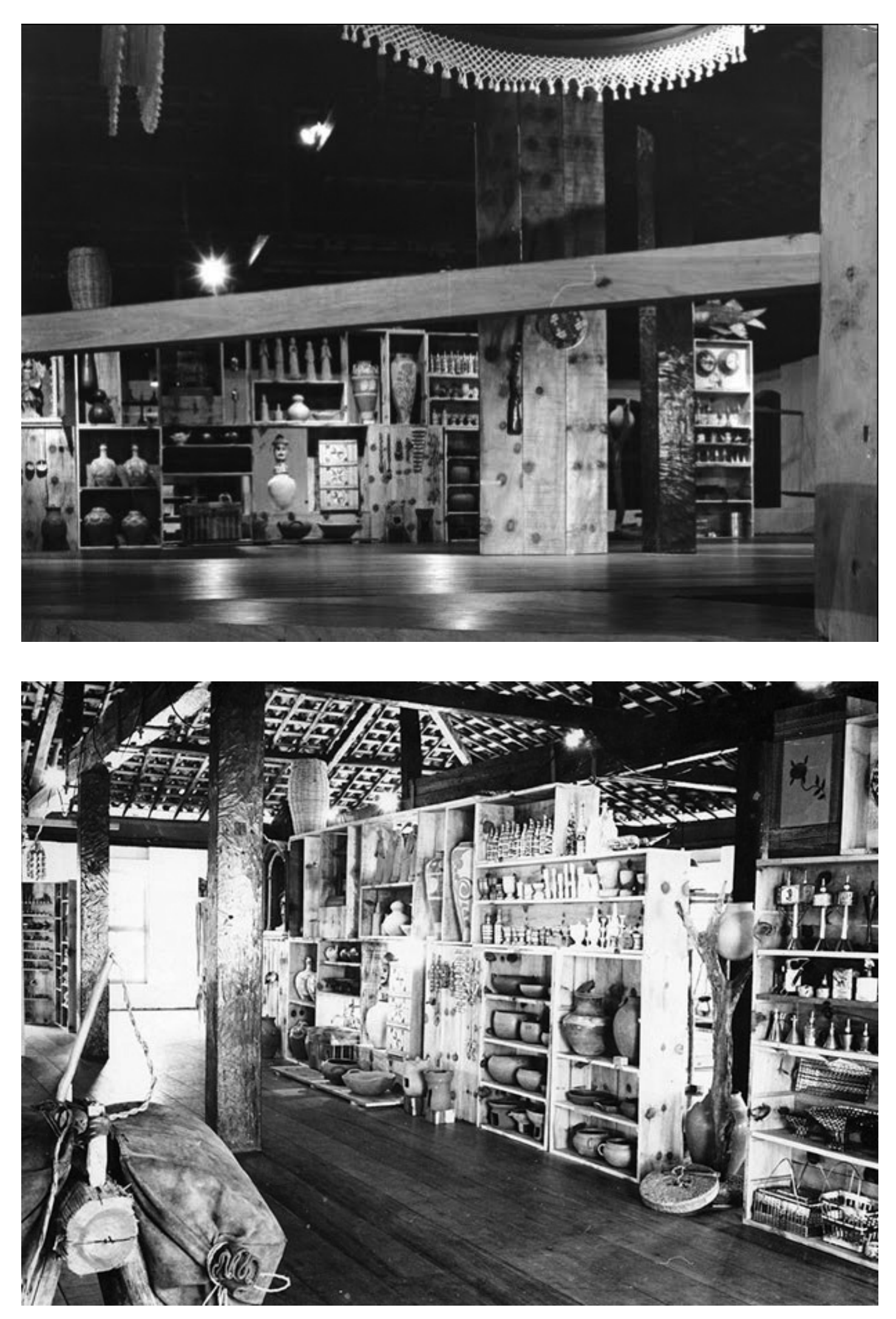

Exposição "Nordeste, realizada em 1963 no recém-inaugurado Museu de Arte Popular, concebido por Lina Bo Bardi. Muitos dos objetos apresentados faziam parte da coleção que a própria arquiteta foi de
TORRACA, G. (2014). p. 135. cia de objetos disposta pelo espaço de forma que pareciam pertencer a famílias ou grupos:

\section{As cuias de cerâmica, por exemplo, foram dispostas de acordo com a sua altura em prateleiras de madeira bruta, enquanto que os lampiões na plataforma adjacente contrariavam este princí pio hierárquico e sugeriam um padrão puramente morfológico. Outros objetos, como uma pedra de moinho, foi pousada no chão como se para venda no mercado local. Enquanto o amplo display de Bo Bardi afirmava a função básica do ordenamento - de um sistema - como uma forma de recuperar para os artefatos po- pulares significados que havia, em grande parte, deixado de ter valor, também deixava os objetos exporem o caráter arbitrário de qualquer tipo de ordenamento. Basicamente, os objetos foram autorizados a falar sobre si. ${ }^{44}$}

Podemos, com isso, especular que o minimalismo e a limpeza do desenho do cavalete, apesar de estar ligado a uma linguagem moderna - referenciada nos italianos do pós-guerra - poderia então ter, na forma que foi disposto no espaço, agregado em seu discurso um pouco dessa compreensão de Lina sobre esses empilhamentos das feiras, que criariam, nessa situação, sobreposições visuais das obras e a consequente multiplicação das possibilidades de interpretação do espaço e de seu conteúdo.

Cabe lembrar, como já apontado no primeiro capítulo dessa dissertação, que Lina não foi a primeira a desenvolver um sistema expográfico que buscasse dar certa autonomia às obras no espaço e à maneira do público vivenciá-las. Pesquisas apontam para arquitetos que desde os anos 30 trabalhavam com essa ideia e que influenciaram o pensamento de Lina, como Eduardo Persico, Franco Albini, Frederick Kiesler, entre outros. 4 BUERGEL, Roger M. 'This Exhibition Is an Accusation. The Grammar of Display According to Lina Bo Bardi. In: Afterall Magazine, 2011. http://www.afterall.org/journal/ -bardi1 (Tradução livre do original em inglês) 
Todos estes arquitetos buscavam, exatamente como o faz Lina Bo Bardi, criar com seus sistemas expositivos, um ambiente ou uma "atmosfera" de aproximação tanto entre as obras expostas como entre o visitante e a obra de arte. ${ }^{45}$

Também vale lembrar que as mais variadas formas de montar exposições já foram adotadas no MASP, sempre de acordo com a demanda de cada exposição. O cavalete é o módulo expositivo utilizado unicamente na composição da pinacoteca, e nesse sentido os críticos exageram quando afirmam que ele imobiliza a coleção, já que pinacotecas em geral são espaços que permanecem mais estáticos, com exposições permanentes. Quem visita o Louvre sempre sabe onde encontrar a Monalisa, por exemplo. Porque exigir do MASP que ele seja também nisso diferente de todos os outros? É na pinacoteca que, estática ou não, esse museu encontra o espaço de maior liberdade e eloquência, com um discurso que muitos podem não concordar, mas que é único e fala sobre a identidade dessa instituição e do lugar onde ela está. Todos os outros espaços do museu tem sua identidade construída a partir do tema de sua exposição, como em qualquer outra instituição.
3.2 Um museu que passa a negar a si mesmo: a supressão da transparência

Foi uma grande polêmica quando o MASP reabriu suas portas em 1996, após um período de reforma, e revelou uma radical transformação do espaço de exibição do acervo. Sem abrir espaço para discussões - e não muito tempo após o falecimento de Lina, em 1992, e o declínio da saúde de Pietro, já afastado da direção - a nova diretoria do museu, presidida pelo arquiteto Julio Neves, extinguiu sumariamente qualquer rastro da expografia idealizada por Lina. Ao selar os vidros do grande salão do acervo com paredes, o novo projeto impediu, assim, qualquer contato visual com o exterior do prédio. Eliminaram-se também todos os cavaletes de vidro, prontamente substituídos por paredes divisórias que organizavam as obras "à moda internacional", por períodos, estilos ou temas. Em texto que discute o papel desse museu transparente para a cultura brasileira na segunda metade do século XX e a atualidade de sua concepção, Renato Luiz Sobral Anelli encerra com uma afirmação afiada, que aponta essa ação de desmonte como um enorme desrespeito ao legado de uma arquiteta que, como poucos, olhou para o Brasil e produziu pensamento e arquitetura correspondentes à complexidade de nossa cultura. Para ele, "o caráter do Masp é muito forte para permitir que ele se torne o oposto daquilo para o qual foi concebido". ${ }^{46}$

Uma comparação entre duas imagens é emblemática sobre a falta de compreensão da então diretoria em relação ao projeto total que era o do MASP. A célebre imagem de Lina junto a um dos cavaletes que suporta um Van Gogh, no espaço ainda em construção do museu, fala sobre como o projeto é completo quando ele acontece de forma generosa, estabelecendo contato direto com a cidade e com

\footnotetext{
Bardi, 2006. In VITRUVIUS: http://www vitruvius.com br/revistas/read/arquitextos/06.068/387
}

46 http://www.vitruvius.com.br/revistas/read/ arquitextos/10.112/22. 


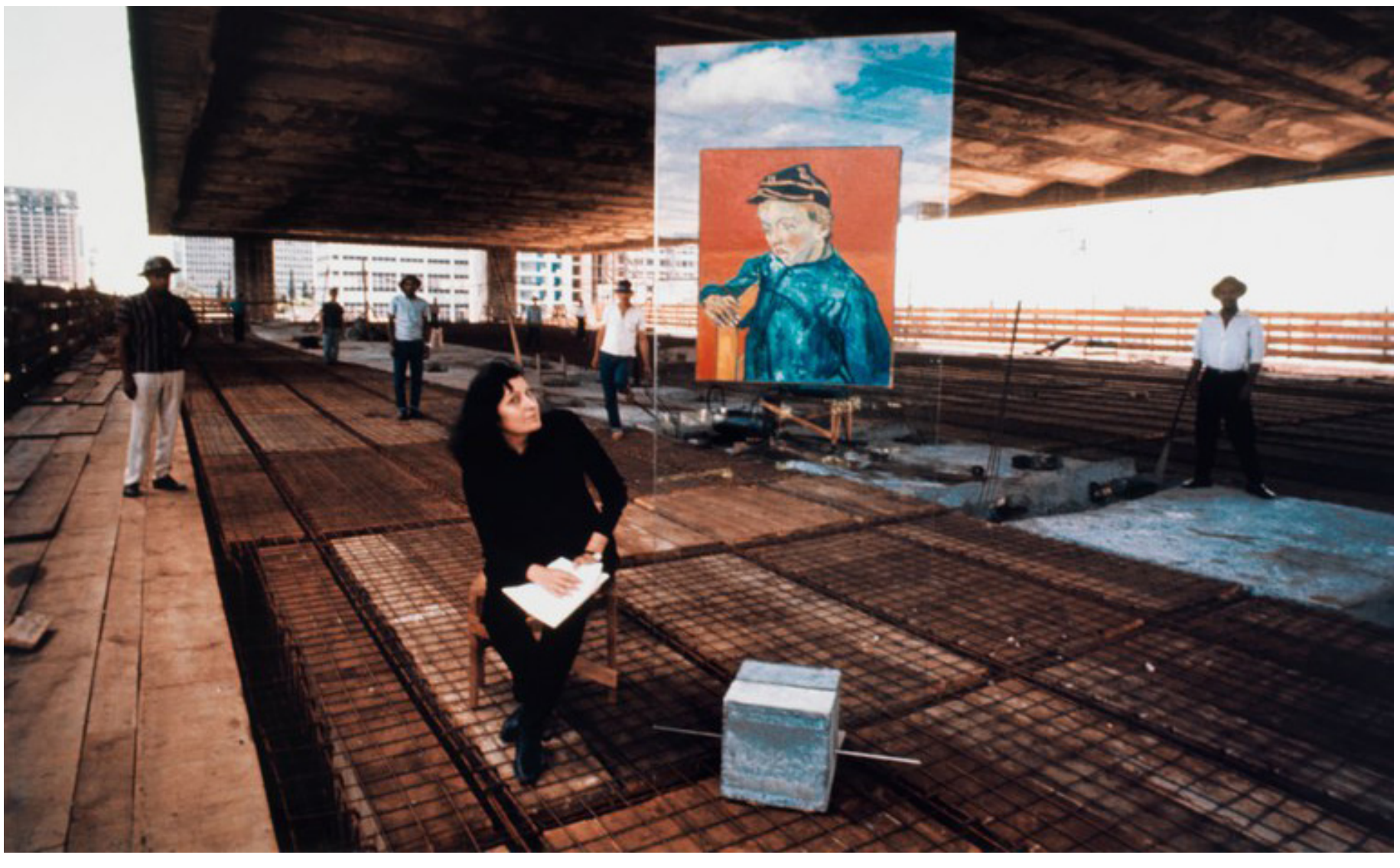

Masp em construção. Lina Bo Bardi ao lado da pintura "O escolar", de Van Gogh. Foto Lew Parrela

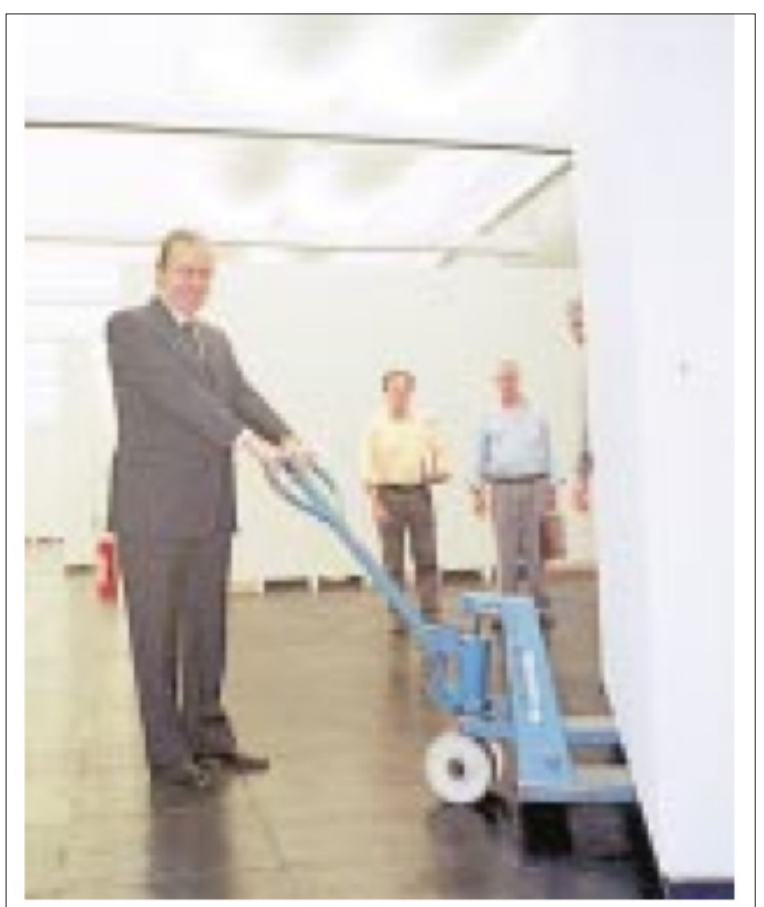

Julio Neves, diretor do Masp, brinca

com uma das paredes de madeira que

hoje sustentam obras na pinacoteca,

em vez dos antigos cavaletes

Fonte: Jornal da Tarde - Terça-feira, 20 Mar 2001 o público. E esse conceito, na imagem do edifício em construção, já está vivo e evidente. Na foto seguinte, de 1996, temos o diretor Julio Neves, contente, segurando um carrinho de carga que contém uma das paredes de madeira que seriam usadas para transformar o espaço em um museu "mais ao gosto internacional". A ironia é que, nesse primeiro momento, as paredes, desenvolvidas em parceria com o arquiteto Vasco Caldeira - então gerente de exposições do museu -, haviam sido pensadas como solução provisória. Porém acabaram por se consolidar como padrão no espaço até o momento atual.

Julio Neves achava que a escolha pela remoção dos cavaletes, a partir de seu ponto de vista conservador e alinhado às tradições da museologia internacional, iria transformar o MASP num museu mais didático, como afirma em conversa com a Folha de S. Paulo:

Tudo isso foi feito para ter um museu didático, mas se amanhã quisermos, tiramos tudo, é só pôr um "jacaré" (máquina como um macaco de automóvel) e mover os painéis", prossegue, referindo-se aos painéis (projetados por seu escritório) que estão lá hoje.47

O professor e arquiteto Guilherme Wisnik, em depoimento realizado em agosto de 2014 para essa dissertação adianta sobre esse tópico questões importantes, que nos levam a olhar para o acontecido de forma mais abrangente:

É importante lembrar que essa visão do Luis Marques e do Julio Neves espelha uma visão que não é de pouca gente. Muitos tem raiva dos cavaletes, acham que aquilo é ultrapassado, anacrônico. E não só os cavaletes. O problema começa pelas fachadas de vidro. Foi nos anos 90 que as requisições museológicas começaram a ficar muito mais rigorosas. As obras de arte também começaram a valer muito mais. Somado a isso, tínhamos a preferência por essa total assepsia do cubo branco, a ideia de que o espaço de exposição precisa ser completamente protegido, neutro. $E$ os grandes arquitetos de museus daquele momento - Renzo Piano, Alvaro Siza, são arquitetos

47 Folha de S. Paulo, Caderno llustrada, 11 de março de 2000. 
de espaços internos mais neutros, que fazem projetos considerados não-interferentes. São os arquitetos que os artistas gostam, porque deixam o protagonismo para a obra de arte. De certa forma é legítimo. Mas é oposto ao raciocínio que norteou o projeto da Lina Bo Bardi. Porém era o raciocínio dominante, moderno.

É fato que muitas críticas válidas foram feitas ao projeto de Lina desde sua inauguração. De questões técnicas reais - como o problema da falta de controle de iluminação do espaço expositivo, o que poderia prejudicar as obras - até a instabilidade dos cavaletes, que vibrariam por conta do trânsito e do metrô e poderiam se quebrar, sujeitando a obra a uma queda bruta. O professor de História da Arte, Luiz Marques, ex-curador do MASP, alega que "parafusar quadros em vidro nunca foi solução museológica”. Segundo ele, a solução de Lina Bo Bardi "permaneceu isolada porque nenhum museu de pintura a adotou" 48 , o que evidencia uma grande indisposição em lidar com os desafios que a originalidade daquela proposta apresentavam.

As críticas falam de problemas reais e bastante complicados de serem contornados, à medida que a origem dos questionamentos está diretamente relacionada com a origem da solução formal do museu. Não há em lugar nenhum do mundo um museu cujas faces sejam totalmente transparentes e suscetíveis à livre entrada de sol, assim como permanece única a solução de pendurar quadros em painéis de vidro aglomerados em uma grande sala. São problemas que, à época da criação do espaço, não eram discutidos de maneira tão aprofundada. Todos os cuidados extremos com conservação e a tecnologia desenvolvida para assegurar os mais adequados padrões de controle de luz, umidade e segurança só entraram de maneira mais forte em pauta na passagem da década de 80 para a de 90 . O que Lina encontrou naquele momento foi uma espécie de brecha que a permitiu explorar uma possibilidade ousada de estrutura museológica, a qual se provaria, apesar de revolucionária e libertadora, museologicamente bastante complicada.

48 Cf. "MASP" in: Jornal da Tarde [coluna do leitor]. São Paulo, 03 abr. 2001.
Porém, a ideia de simplesmente se livrar do problema - sem refletir sobre as razões que deram origem a esse formato de museu ou se há uma possibilidade de meio-termo - reflete uma ignorância em relação aos caminhos que instituições museológicas em geral tentam trilhar nas últimas décadas, frente às enormes transformações do conceito de cultura e entretenimento que, inevitavelmente, colocaram em cheque as estruturas tradicionais das exposições.

O curador alemão Roger M. Buergel, em texto escrito em 2011, destaca de maneira objetiva e potente o quanto foi perdido pela falta de compreensão do projeto de Lina para o MASP. O título, em tradução livre "Essa exposição é uma acusação: a gramática do display segundo Lina Bo Bardi” já declara o tom de manifesto. O autor aponta duas razões fortes que, segundo ele, colocam o legado de Lina Bo Bardi num lugar especial na história da arquitetura, da tecnologia do display e do senso de textura espacial:

A primeira razão é artística: a estagnação formal que assola o design de exposições contemporâneas. Enquanto curadores desejam falar de forma ininterrupta sobre mediação (e são ensinados em tantos cursos de curadoria a fazer exatamente isso) a questão do display segue vergonhosamente negligenciada. A arte é feita para parecer como se estivesse amarrada a nada mais do que a produção artística em si, enquanto o contexto é reduzido a mero texto. A segunda razão é política: Bo Bardi é excepcional em seu entendimento formal da entidade igualmente vasta e misteriosa chamada "o social". Sua poética da colaboração sensual poderia ser o antídoto às inclinações populistas das instituições de arte ocidentais (incluindo a predileção delas por grandes exposições).49

Buergel, que já foi curador da Documenta de Kassel, entre outras importantes exposições, é uma das fortes vozes internacionais que tentam colocar a importância dos cavaletes de cristal de volta à pau-

49 http://www.afterall.org/journal/issue.26/this-exhibition-is-an-accusation-the-grammar -of-display-according-to-lina-bo-bardi1 (Tradução livre do original em inglês) 
ta, atacando a ignorância daqueles que não souberam lidar com os desafios naturais que o projeto veio a apresentar com o passar do tempo. Em outro trecho, Buergel escreve:

Aprender com Bo Bardi hoje implica conceber instituições em termos de autoperfuração, em termos de sua própria ruína. Elas têm que aprender a dramatizar seu dilema-chave - ou seja, o que conto como ensinável e por quê. Tentar sintetizar um "gold-standard" do conhecimento legítimo em um mundo de cânones em ruínas é ridículo. Tentar sintetizar a sensualidade contemporânea é ainda pior. É necessário uma metodologia que aborda o público nem como consumidores nem como crianças, mas como parceiros. ${ }^{50}$

Fica claro que o desejo de discutir a atualidade do projeto de Lina Bo Bardi parte de uma necessidade de se criarem novos parâmetros frente a uma espécie de paralização da capacidade de as exposições lidarem de maneira produtiva e construtiva com seu público. E Buergel, como muitos, enxerga na construção de um diálogo generoso com o público, uma possível saída para a experiência repetitiva de visitar um museu que, por sua neurtalidade, poderia estar em qualquer lugar do mundo.

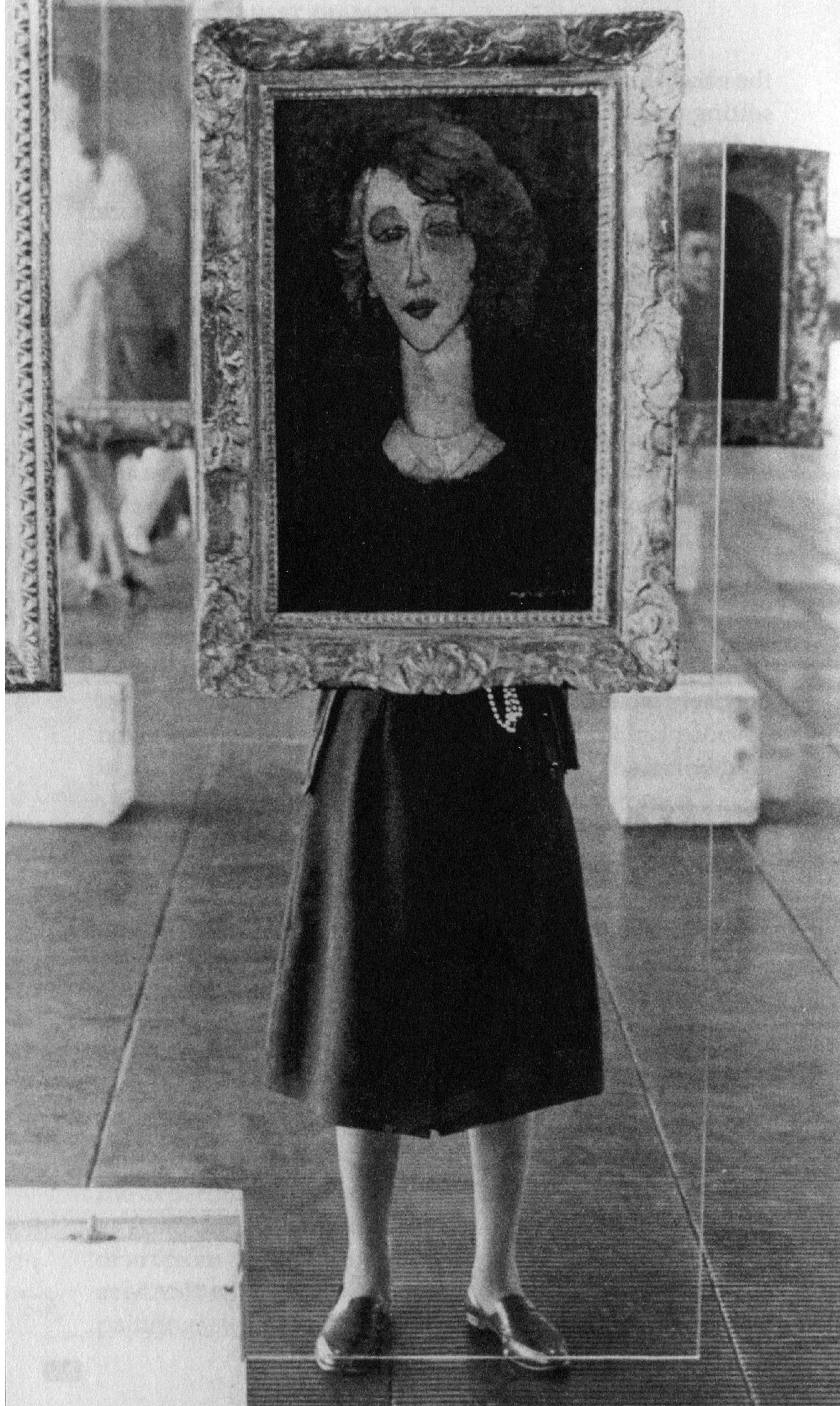




\section{O USO CONTEMPORÂNEO DO CAVALETE DE CRISTAL}

Há uma ironia ao percebermos que a eliminação da museografia e funcionamento arquitetônico do MASP acontece concomitantemente a uma crescente onda de estudos internacionais, que colocam Lina e seu cavalete de cristal na ponta de uma importante reflexão sobre necessárias mudanças na forma de se apresentarem obras de arte no contexto museológico contemporâneo.

Lina não poderia prever sua própria sina: o MASP - pensado para ser um museu transparente, fluido, em contato com a cidade e com uma museografia para ser vivenciada pelo público de maneira livre - justamente por ser exceção acabou numa posição de fragilidade. Sobre isso, Aldo van Eyck escreve:

A exposição, sendo única, é, em consequência, também anormal. E o que é anormal - neste caso à revelia, devido a seu caráter único também é vulnerável no sentido de que corre o risco de ser mudado ou desmantelado completamente, o que seria uma perda inominável. Seja como for, agora o problema tornou-se agudo. ${ }^{51}$

De fato, a singularidade do projeto foi seu calcanhar de Aquiles. Após 25 anos do museu em funcionamento, sem aviso prévio, o MASP teve seus órgãos mais vitais suprimidos: o edifício perdeu seu contato com a cidade, as obras perderam seu campo de trocas e 
contaminações com o público. O MASP, após a reforma conduzida pelo então diretor Júlio Neves e curador Luiz Marques, passou a "negar a sim mesmo" - como bem aponta Renato Anelli. Apesar disso, não cessam de surgir pelo mundo projetos e textos que dialogam com a extinta museografia, sempre num tom de valorização de um partido que, hoje, possibilita reflexão sobre possíveis novos rumos para a forma de se mostrar arte. Os cavaletes de vidro estão na ponta da língua de curadores internacionais, artistas e pesquisadores das mais renomadas universidades do mundo. Os projetos aqui levantados demonstram sua potência, a qual resiste apesar de sua extinção. Para além da solução formal, o cavalete e o espaço do MASP propõem uma importante discussão sobre o papel da arte em nossa sociedade hoje e, também, sobre o desejo de tornar o público partícipe da construção dessa relação.
4.1 Levantamento de projetos atuais que revisitam o display ${ }^{52}$

\section{6 - Londres}

Reforma da National Portrait Gallery

Arquiteto Piers Gough

Em 1996, ano que coincide com a retirada dos cavaletes de cristal, todo o primeiro andar da National Portrait Galery, em Londres, foi redesenhado pelo arquiteto holandês Piers Gough para exibir a coleção de retratos vitorianos e do início do século XX. O arquiteto, de perfil eclético, decidiu criar nesse espaço um efeito de salão de festas onde poderíamos nos deparar com diversas personalidades da história. Para criar essa ambiência, Piers Gough decidiu suspendendo os retratos em paredes inteiramente de vidro. As obras, assim, flutuavam no espaço da sala, convidando o espectador para uma espécie de jogo - onde não só quadros, mas também o público era envolvido pela transparência e multiplicação. Focos de luz foram desenvolvidos para evitar reflexos nesses panos de vidro. Janelas existentes que haviam sido seladas foram reabertas para que a luz do dia pudesse iluminar todo o espaço perpendicularmente às paredes - trazendo o exterior de volta ao espaço, mais à maneira de uma residência.

Conforme levantado pela pesquisadora Olivia de Oliveira em seu livro "Lina Bo Bardi - Sutis Substâncias da Arquitetura", o arquiteto explica, em carta enviada para o Instituto Lina Bo e P. M. Bardi, que sua proposta de expor "as pinturas sustentadas em paredes de

52 Muitos outros eventos e projetos relacionados a Lina Bo Bardi foram realizados nos últimos 20 anos, tais como a exposição Together: Lina Bo Bardi (Basel, 2012 - curadoria: Hans Ulrich Olbrist), entre tantos outros Porém, iremos destacar aqu' somente os que envolvem diretamente uma discussão acerca do Cavalete de Cristal e do MASP 
vidro" recebeu "influência direta do projeto de Lina para o MASP" - o que fica evidente ao observarmos o feito conseguido na imagem abaixo. O interesse na construção de uma relação entre as obras, e entre público e obra, reflete algumas das intenções que Lina teve ao desenvolver a museografia do MASP.

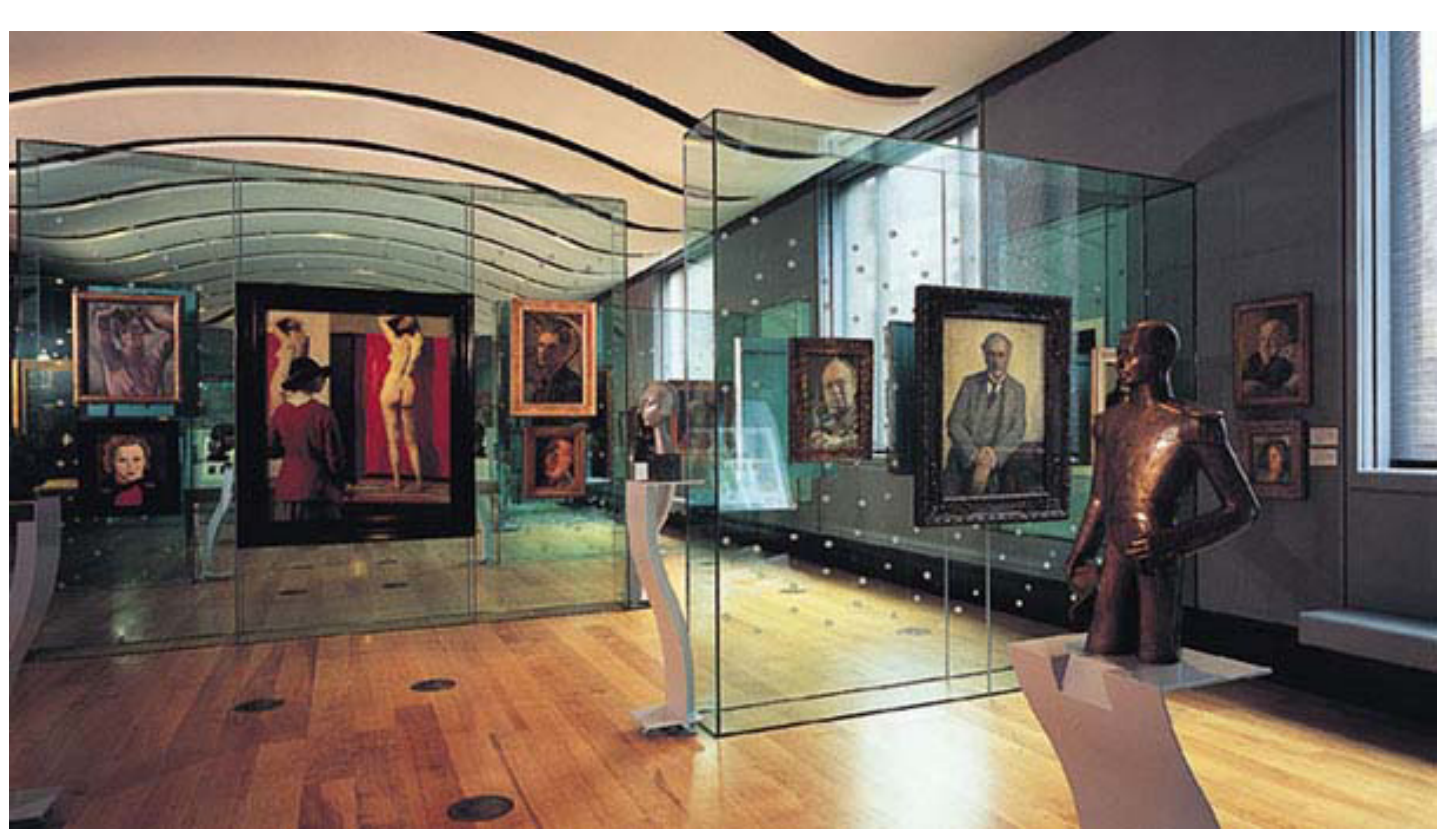

Vista do andar reformado da National Portrait Gallery. Fonte: http://www.czwg.com/

É interessante observar a releitura que Gough faz do cavalete de Lina: aqui, ele utiliza o próprio vidro para criar uma caixa autoportante, não precisando, assim, de uma base em um segundo material. Essa solução, claro, deixa de lado outros aspectos envolvidos na concepção do cavalete de Lina - que possibilitam ao espectador contornar uma obra e ter contato com um extenso conteúdo a seu respeito. No caso de Gough e sua caixa de vidro, o que se encontra do lado oposto de cada caixa são mais obras. Outro dado que vale ser observado nesse projeto é a furação das placas de vidro. Como podemos ver na imagem, Gough optou por criar um amplo grid de furação, o que permitiria a fixação de telas de variados tamanhos. Esse era um dos problemas encontrados nos cavaletes de Lina: cada vidro era pensado especificamente para um quadro - o que limitava bastante a possibilidade de fazer mudanças na curadoria de forma simples.
1997 - São Paulo

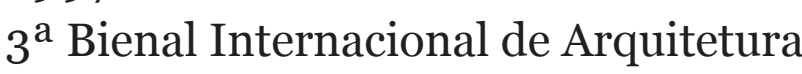

Os cavaletes de cristal banidos da pinacoteca do MASP, em 1996, reapareceram no ano seguinte na $3^{\text {a }}$ Bienal Internacional de Arquitetura, no Parque Ibirapuera - servindo de suporte para parte de uma exposição de fotos, desenhos e textos inéditos que contavam a história da construção do MASP. Foi uma maneira de trazê-los a público para problematizar sua recente supressão. Eles retomavam a urgente necessidade de olhar com mais cuidado para o valor único do projeto cultural que a arquiteta tinha proposto para o MASP, e que acabava de ser quase completamente extinto devido à reforma conduzida pelo então diretor, Júlio Neves, e sua equipe.

Em texto que acompanhou a exposição da Bienal, Lina ressaltava que o sistema dos cavaletes visava "criar no visitante a forma mental adaptada à compreensão da obra de arte”. Em matéria divulgada pela Folha de S. Paulo durante o evento, encontramos o trecho:

Depois de quase 30 anos, a proposta de Lina impressionou os curadores do museu dedicado ao arquiteto holandês Gerrit Thomas Rietveld (1888-1964), que viram a mostra sobre o Masp ao visitarem a Bienal Internacional de Arquitetura. "Eles gostaram da ideia, nos pediram e estamos enviando os desenhos e as medidas para que reproduzam os cavaletes no museu Rietveld”, conta Ferraz. ${ }^{53}$ 
2000 - Chicago, Illinois - EUA

Cavaletes do MASP no Crown Hall

O Crown Hall, edifício projetado por Mies van der Rohe, em 1950, para o Illinois Institute of Technology, é localizado em Chicago. O edifício, assim como outros projetos do arquiteto, carrega evidentes semelhanças com o MASP: uma grande caixa de vidro, com planta livre, pensada de maneira flexível. Finalizado em 1956, ficou mundialmente famoso por empregar uma nova tecnologia de uso combinado de aço e vidro. Mies chamou o piso principal de "espaço universal" e foi projetado para ser totalmente flexível na sua utilização. A divisão dos espaços é feita por painéis leves e móveis, facilmente deslocáveis para reconfigurações desse ambiente.

A universidade solicitou autorização do Instituto Lina Bo e P. M Bardi para reproduzir os cavaletes, que serviriam de base, nesse mesmo salão principal, para receber a exposição de duzentos desenhos da arquiteta, em abril de 2000.

O arquiteto e colaborador de Lina, Marcelo Ferraz, destaca em entrevista para a Folha de S. Paulo que "o que o Brasil abandona está sendo revisto no exterior".

As réplicas do cavalete foram, posteriormente, incorporadas pela instituição, e ficaram por muito tempo na área de entrada do prédio. Esporadicamente, continua sendo usado como display para outras exposições. Sobre esse caso, a pesquisadora Olivia de Oliveira escreve:

O interessante é que os argumentos que vêm sendo utilizados para "purificar" e renegar a arquitetura e sistemas de exposições previstos para o Masp são diametralmente opostos aos utilizados por especialistas de outros museus. Oitenta réplicas destes mesmos cavaletes relegados ao porão do Masp, atualmente integram uma das principais obras construídas pelo mestre da arquitetura moderna Mies van der Rohe: nada mais nada menos do que o Crown Hall, o salão principal de exposições do Instituto de Tecnologia de Illinois em Chicago. ${ }^{54}$
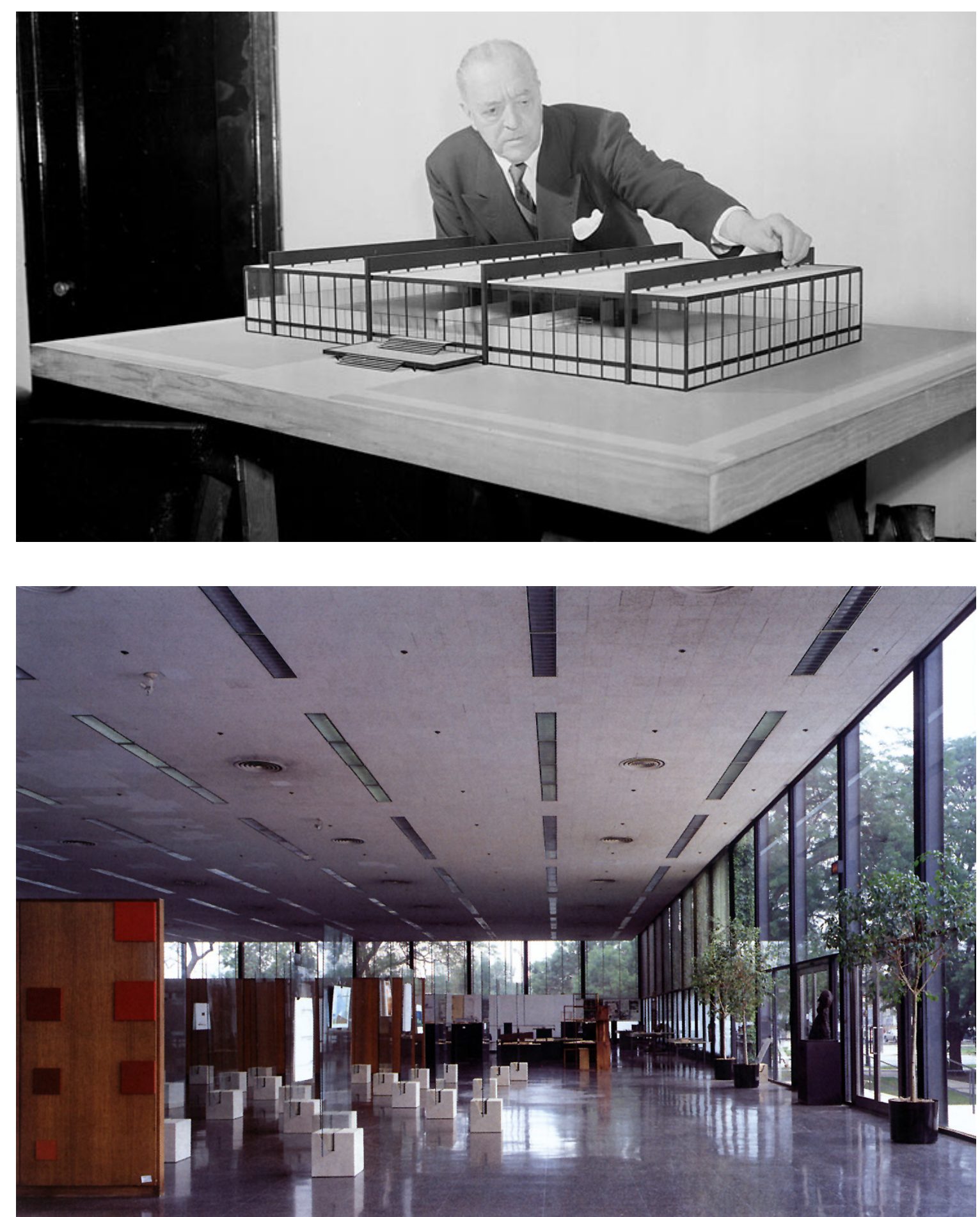

54 OLIVEIRA O Repasses: a depredação material e espiritual da obra de Lina Bo Bardi. 2006. http://www.vitruvius.com.br/revistas/read/arquitextos/06.068/387 


\section{6 - São Paulo}

Lina Bo Bardi - Arquiteto | Exposição realizada no MASP

A exposição Lina Bo Bardi - Arquiteto, concebida pelos curadores italianos Luciano Semerani, Antonella Gallo e Giovanni Marras e exibida, originalmente, na $9^{\text {a }}$ Mostra Internacional de Arquitetura de Veneza, em 2004, trouxe para o MASP, em 2006, cerca de duzentas obras e desenhos originais da arquiteta. Para homenageá-la, o arquiteto responsável pelo projeto expográfico do evento, Vasco Caldeira, promoveu algumas mudanças no espaço interno do subsolo do museu, abrindo uma das muitas paredes criadas por Julio Neves e que comprometiam, totalmente, o contato do público com o exterior do edifício. O público podia, durante essa exposição, vislumbrar uma brecha do que foi a concepção original do subsolo que, ao contrário do que se espera desse tipo de espaço, nada tinha de sombrio ou selado antes da interferência.

Os cavaletes originais projetados pela própria Lina Bo Bardi são retomados aqui com a intenção de dispor com fluidez os conteúdos da exposição. Porém, o que acabou acontecendo foi um uso que pode ser visto como, de alguma forma, equivocado da peça: a iluminação colocada acima de cada cavalete gerava uma profusão de sombras e reflexos, os quais evidenciavam a presença física do cavalete ao invés de criar diálogos entre os conteúdos expostos. A peça, pensada para quase invisibilidade, ganhava o primeiro plano. Podemos entender que essa pode ter sido uma estratégia para evidenciar a ausência do cavalete, porém nada da exposição falava de maneira clara sobre isso, e a impressão que ficou é a de fetichização do display.

Críticos da direção que atuava no MASP naquela época avaliaram que era, no mínimo, "irônica" a decisão de celebrar a obra da arquiteta num local em que sua obra acabou sendo tão desrespeitada.
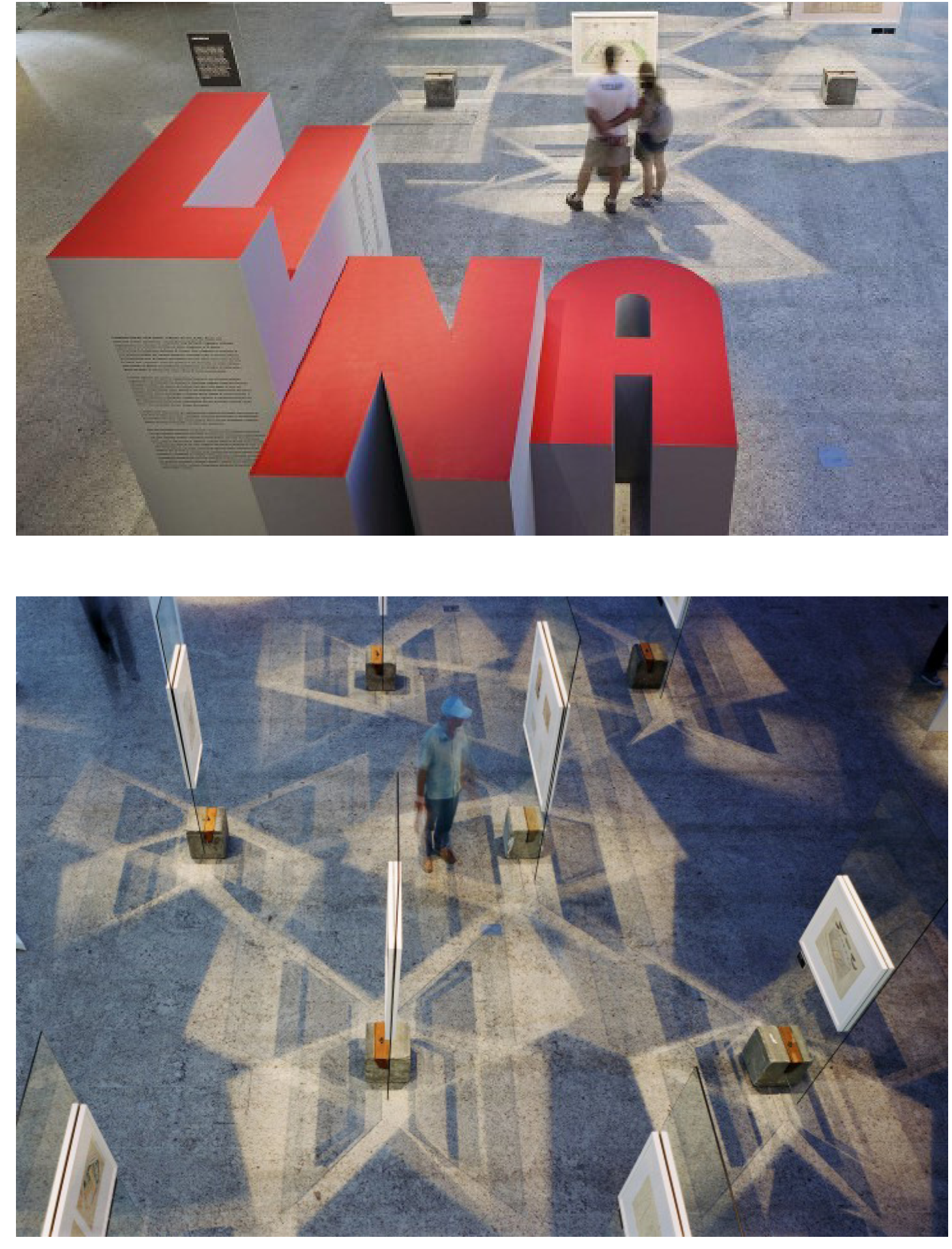

Vistas da exposicão. Fonte: ART UNLIMITED, Disponivel em: http://artunlimited.com. br/ index.php/portfolio/lina-bo-bardi-arquiteto/ 


\section{1 - Holanda}

Duas propostas do Van Abbemuseum

O Van Abbemuseum é uma instituição que se destaca como uma das maiores pesquisadoras de novas formas de desenvolver exposições. Possui um interessante programa de exibições intitulado "Play Van Abbe" que, em sua segunda edição, trabalhou com o conceito de reencenação com o projeto "Time Machines: reloaded exhibition" (em tradução livre, "Máquinas do Tempo: exposições retomadas"55). A ideia de repetir exposições do passado para gerar um entendimento atualizado sobre elas é um movimento que merece atenção nos últimos dez anos. Isso atesta a importância do fenômeno da exposição nas sociedades de hoje e aponta para um interesse na história de exposições, na memória coletiva gerada por elas e nos cruzamentos da teoria e da prática de exposições passadas com preocupações contemporâneas. A pesquisadora e escritora Reesa Greenberg afirma que:

O surgimento do [conceito] "lembrando exposição" é uma manifestação de fascinação atual da cultura ocidental que trata a memória como uma modalidade para a construção de identidades individuais ou coletivas. A forma como nos lembramos de exposições e nossa necessidade de lembrar delas são uma parte muito importante da recente cultura de exposição."”6

Esse programa abordou o Cavalete de Cristal de Lina Bo Bardi de duas formas: remontando o que seria o espaço museográfico do MASP - em menor escala -, utilizando obras do acervo do Van Abbemuseum, e dando espaço a artistas para criar um projeto autoral que também utilizou os cavaletes. Os dois projetos seguem deta-

\footnotetext{
55 A palavra reloaded, utilizada no nome original da exposição, não possui uma traduçâo adequada para ser utilzada aqui. A traduçăo literal, "recarregada", náo dá conta da ideia que a proposta pretende transmitir e, por isso, foi substituída pelo termo
}

6, http://www.tate.org.uk/download/file/fid/7264 lhados a seguir. Estas apresentações fornecem um olhar inspirador na gênese do museu de arte moderna e contemporânea, ao mesmo tempo que propõem perguntas sobre o seu futuro.

\section{Play Van Abbe - Museum Modules}

Nesse primeiro projeto, os curadores Diana Franssen e Steven ten Thije utilizaram algumas salas do museu para retomar estruturas modulares utilizadas em museus do passado - e que eles julgavam importantes de serem revisitados. O cavalete de Lina Bo Bardi estava entre os selecionados, que foram escolhidos por serem representativos de um momento histórico que transformou a função dos museus - o pós-guerra. O que o museu quer discutir é um eminente esgotamento do modelo do cubo branco, mostrando que esses projetos reapresentados no Museum Modules sugerem diferentes possibilidades de museus que existiram no passado - e que diferentes modelos poderão também existir no futuro.

Para configurar a exposição, o museu conseguiu direito de reprodução dos cavaletes e partiu de seu próprio acervo para desenvolver a exposição. As pinturas escolhidas, por uma decisão da curadoria, deveriam necessariamente ser retratos (Marlene Dumas, Charley Toorop, Asger Jorn e Karel Appel são alguns dos artistas escolhidos). Essa foi uma forma de entrar em consonância com o que Lina mencionava apreciar sobre o projeto do MASP - a simbiose entre visitantes e pinturas no espaço, uma configuração que, segundo ela, fala sobre diversidade e democracia.

Os painéis didáticos também foram elaborados seguindo os preceitos de Lina Bo e Pietro Maria Bardi, oferecendo uma contextualização ampla da obra, além de relacioná-la a outras obras e a seu tempo na história. 
Na situação em que a exposição foi montada - uma sala confinada, sem janelas - seria impossível estabelecer padrões fiéis de fruição e vivência oferecidas pelo MASP, já que no projeto de Lina, a arquitetura completa o funcionamento do projeto - um é parte indissociável do outro.
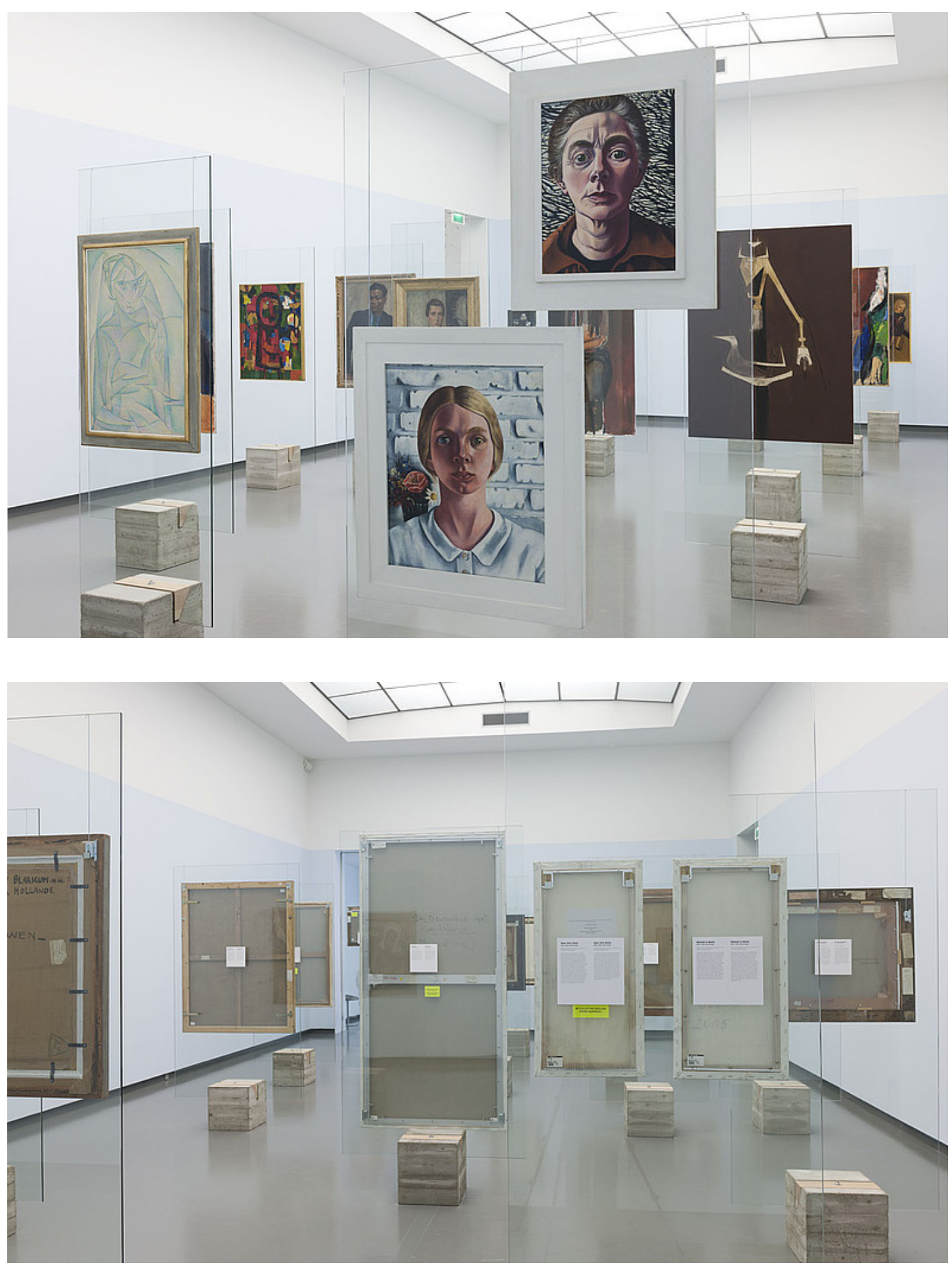

Vistas da exposição. Fonte: Van Abbemuseum - http://vanabbemuseum.nl/
vabdisplay_pi1\%5Bptype\%5D=18\&tx_vabdisplay_pi1\%5Bproject\%5D=692
Lina Bo Bardi - The Didactic Room -

Politics of Collecting - Collecting of Politics

O Projeto "A Sala Didática” foi concebido e desenvolvido pelos artistas Wendelien van Oldenborgh e Grant Watson.

A exposição traz à tona duas características distintivas da prática de Lina Bo Bardi: seu grande rigor em relação às soluções formais dos projetos e, simultaneamente, a enorme liberdade de criar novos caminhos e possibilidades. A apresentação dos trabalhos em seus painéis de vidro é combinada com um programa ativo de atividades relativamente espontâneas que, aos poucos, vai deixando seus resíduos ou resultados agregados aos cavaletes circundantes.

A escolha de obras da coleção da Van Abbemuseum, as quais iriam integrar esse projeto, deu-se a partir de uma busca por aquelas que teriam algum tipo de relação com os pensamentos e práticas de Lina Bo Bardi e com a própria coleção do MASP.

Em depoimento sobre a proposta, Oldenborgh declara:

Este é um espaço dedicado à introdução das línguas formais e sociais desta arquiteta significativa através da reprodução de seus painéis de vidro que ela desenhou para a coleção no MASP, em conjunto com os painéis didáticos (...) Esta sala integra uma exposição chamada "Time Machines", que propõe um estudo de vários modelos de museus do passado, levantando questões sobre o museu no presente e no futuro..$^{57}$

As colagens que ocupavam os painéis didáticos foram, numa primeira fase de desenvolvimento do "roteiro", desenvolvidas em colaboração com Grant Watson. No entanto, sofriam interferências dos próprios visitantes ao longo do tempo. O espaço oferecia uma espé-

57 Wendelien van Oldenborgh em carta para Pablo Leon de la Bara. Fonte:http// centrefortheaestheticrevolution blogspoticom.br/2011/01/lina-bo-barde: hidactic -room-and-lina-bo.html (tradução livre). 
cie de mesa de estudos onde o público podia dispor de diversas publicações, além de materiais de desenho, tesoura e cola. Com isso, eles eram incentivados a pensar sobre as informações que julgavam importantes de constar nos painéis didáticos, acrescentando visões pessoais à curadoria.
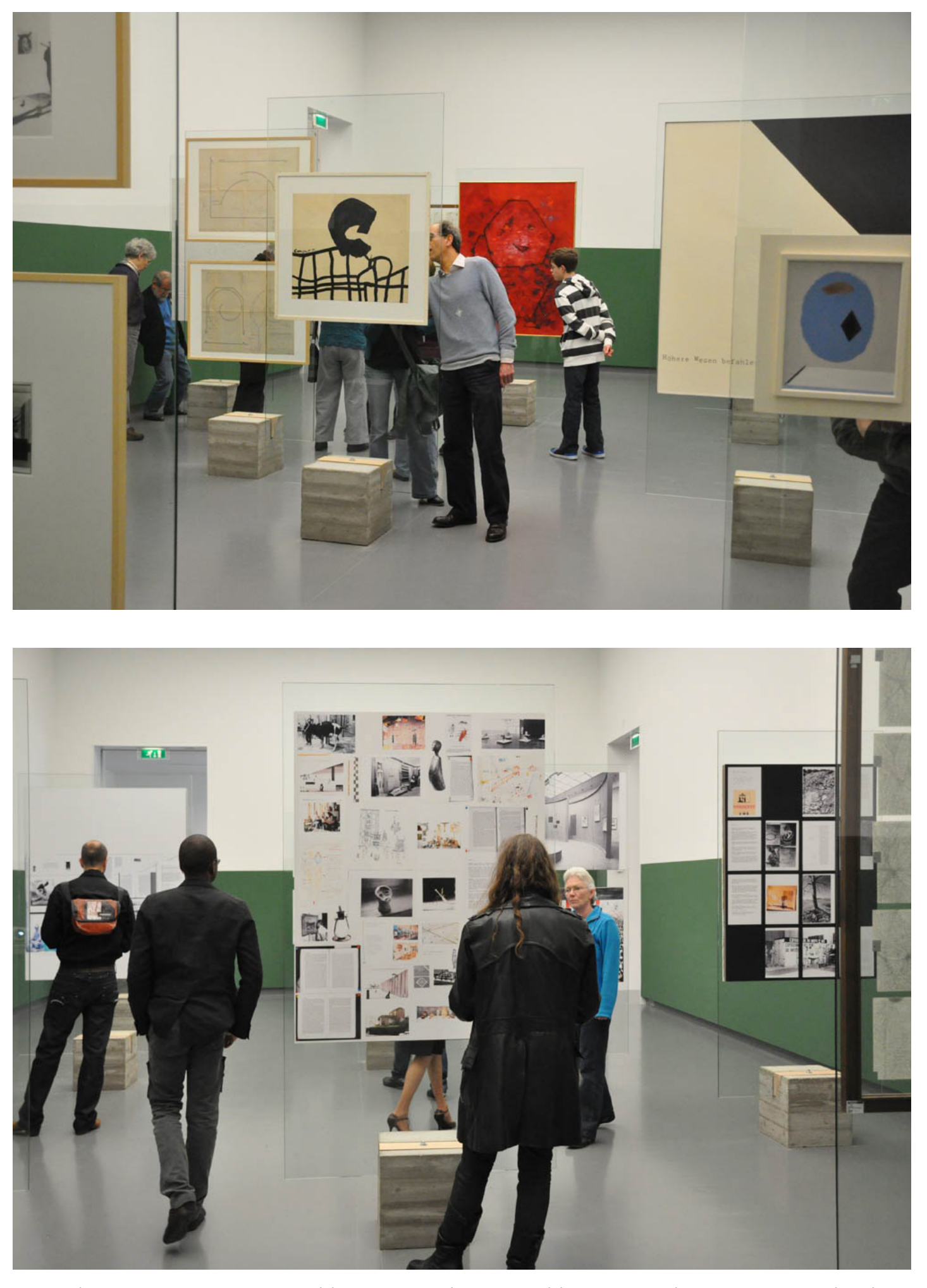

Vistas da exposição. Fonte: Van Abbemuseum - http://vanabbemuseum.nl/
vabdisplay_pi1\%5Bptype\%5D=18\&tx_vabdisplay_pi $1 \% 5$ Bproject $\% 5 D=692$
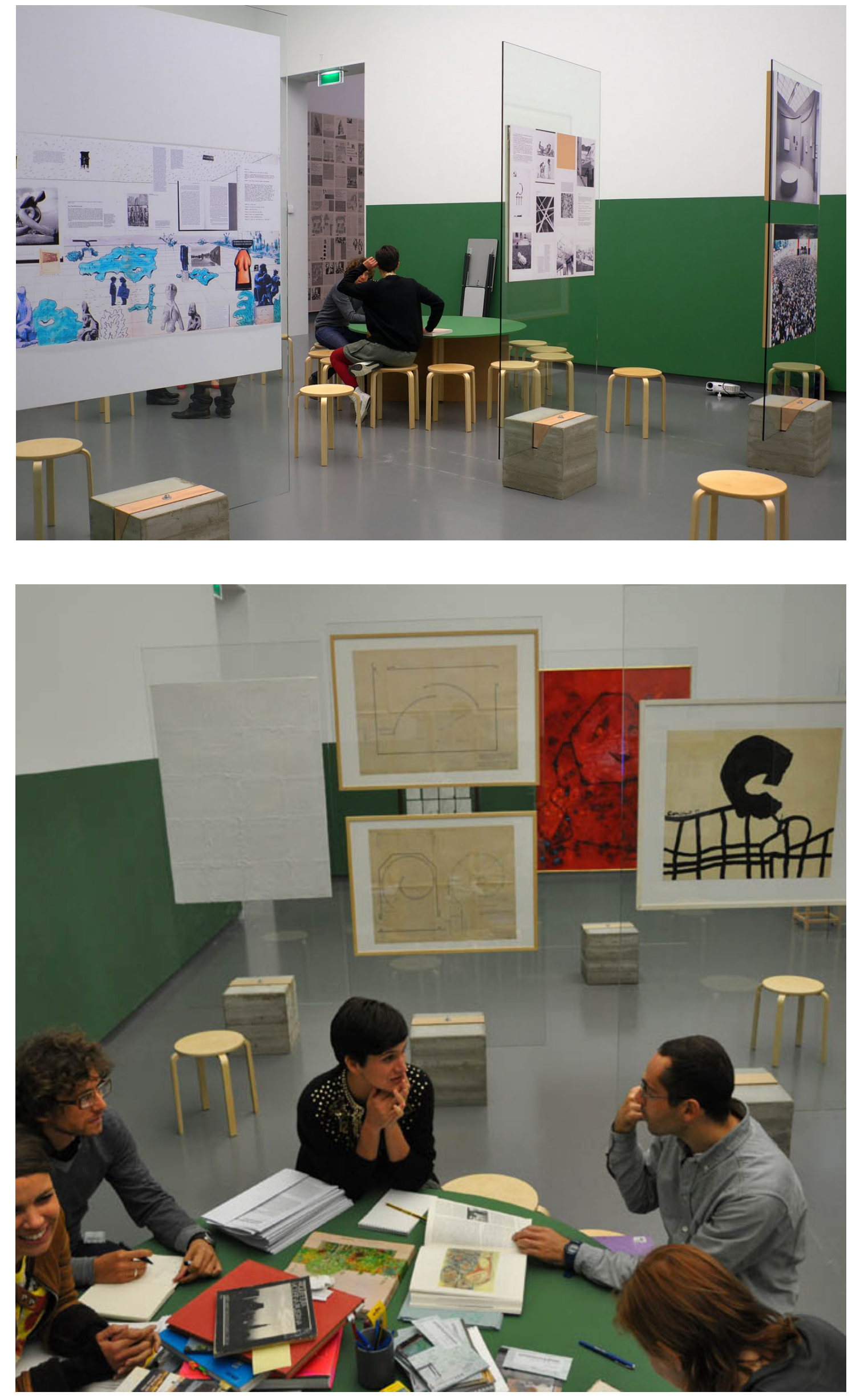


\section{2 - São Paulo}

obra da artista Jutta Koether

$30^{\mathrm{a}}$ Bienal de Arte de São Paulo

A alemã Jutta Koether é uma pintora, performer, musicista, crítica e teórica. Seu conhecimento interdisciplinar é revelado em seu trabalho, que está sempre desafiando normas. Sua exposição, que fez parte da $30^{\mathrm{a}}$ Bienal de Arte de São Paulo - e que foi inserida dentro da exposição permanente no MASP -, integra uma série que a artista vem desenvolvendo nos últimos anos. São pinturas abstratas, coloridas, gestuais e confusas, que produzem releituras pessoais de obras de importantes artistas como Francis Bacon e o clássico pintor francês do século XVIII, Nicolas Poussin. Para a artista, lidar com essas pinturas envolve trazê -las de volta à discussão a partir de novos princípios.

Koether retoma o uso dos cavaletes originais a fim de exibir suas pinturas inspiradas pela obra Himeneu Travestido Assistindo a uma Dança em Honra a Príapo (1634 a 1638). A série foi exibida em frente à própria obra original, que havia acabado de ser restaurada e que compunha a exposição permanente do MASP naquele momento. A proposta, sem dúvida, continha um teor crítico: era uma chance pontual de superar, momentaneamente, as dificuldades que essa instituição tinha de estabelecer uma conexão entre dois momentos de sua própria história. "Demos a possibilidade para ela expor no MASP de uma maneira não disponível para a maioria dos artistas. Criamos mais um diálogo, pois o museu projetado por Lina Bo Bardi recentemente restaurou um quadro de Poussin”, afirma Tobi Maier, cocurador da Bienal em entrevista a Marcos Sanchez. ${ }^{58}$

Como é apontado no texto do catálogo da bienal sobre essa obra, "as instalações resultantes desses trabalhos convidam o espectador a refletir sobre expectativas relacionadas às pinturas, aos displays

58 http://www.dw.de/doze-artistas-alem\%C3\%A3es-participam-da-30\%C2\%AA-bienalde-s\%C3\%A3o-paulo/a-16225156 das exposições e ao contexto institucional no qual o trabalho é apresentado.”59 Dificultar a visibilidade de uma obra-prima da coleção a partir do uso da história dessa mesma instituição é a maneira que a artista encontrou de se infiltrar de forma crítica, despertando um passado que, a seus olhos, não deve ser renegado.

A artista desenvolve essa série de trabalhos há alguns anos e, na elaboração dos espaços de exposição de sua obra, sempre colocou a transparência e a sobreposição como objetivos. Assim, num retrospecto, podemos olhar para várias de suas exibições como espaços que dialogam
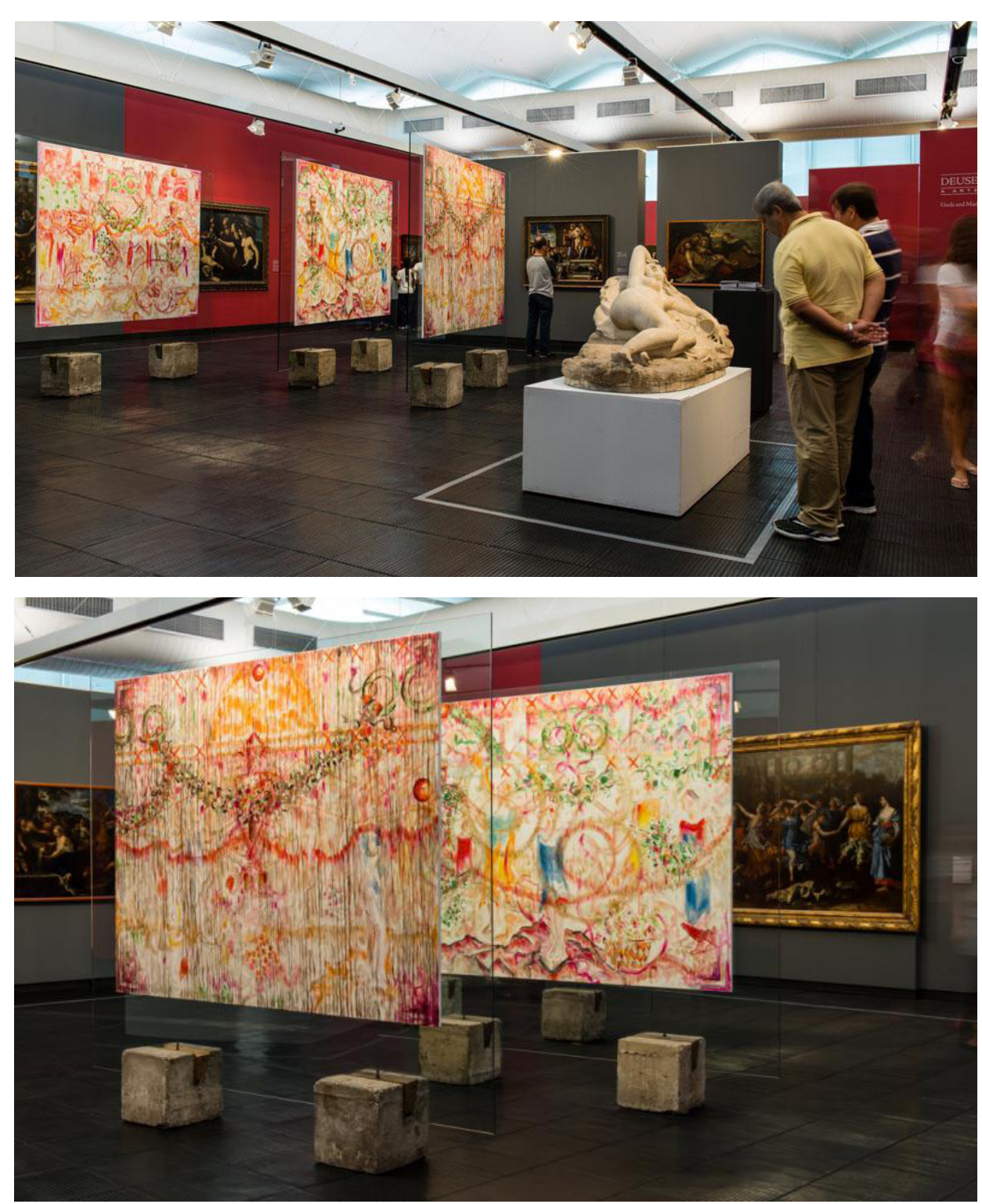

Obra montada durante a $30^{a}$ Bienal de Arte de São Paulo, com os cavaletes originais de Lina Bo Bardi (2012). Fonte: Domus Web - http://www.domusweb.it/es/arte/2012/11/23/ bienal-de-sao-paulo-constelacion.htm

59 In: Trigésima Bienal: a iminência das poéticas. São Paulo: Fundação Bienal, 2012, p. 204. 
com a transparência e contaminação propostas por Lina em sua museografia - algo perceptível nas fotos apresentadas aqui. Foi uma grande surpresa para a artista quando ela tomou conhecimento da existência do cavalete de cristal e de sua supressão no MASP. A possibilidade oferecida pela curadoria de lidar com essa história e de produzir uma série de pinturas baseadas em uma obra da coleção do MASP desde o princípio deu fôlego à obra da artista, que encontrou nos cavaletes de Lina um pensamento alinhado com o tipo de crítica e reflexão que ela queria propor em seu trabalho. Assim, ao desejar fazer referência à arquitetura do museu de Lina Bo Bardi, Koether inventou seu próprio sistema de paredes de vidro. Essa instalação foi mostrada pela primeira vez em 2009 em duas salas do Van Abbemuseum, na Holanda.
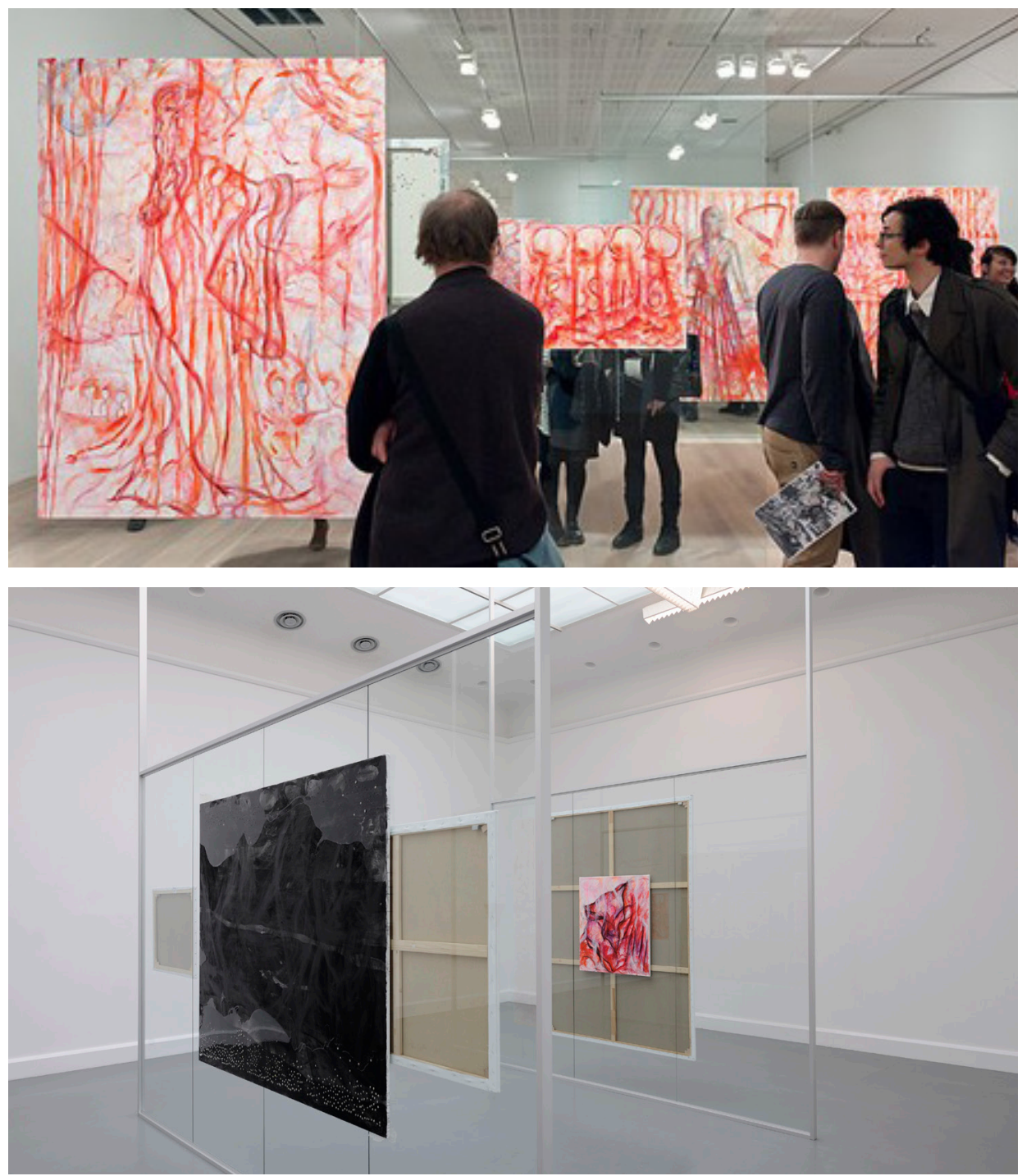

Obras da mesma série expostas no Van Abbemuseum, com displays inspirados no Cavalete de Lina Bo Bardi (2009)
2013 - São Paulo

Modos de Atravessar: o asfalto e a areia

$\mathrm{X}$ Bienal de Arquitetura

A exposição "O asfalto e a areia", que integrou a $30^{\mathrm{a}}$ Bienal de $\mathrm{Ar}-$ quitetura, relaciona a produção de importantes artistas e arquitetos brasileiros, na virada dos anos de 1960 para os de 1970, em torno da promulgação do AI-5: Vilanova Artigas, Paulo Mendes da Rocha, Lina Bo Bardi, Hélio Oiticica e Cildo Meireles.

De acordo com o site da Bienal, "o tema são os constantes atravessamentos entre as esferas pública e privada no Brasil, na forma de casas pensadas como espaços urbanos e instalações artísticas ambientais em lugar público concebidas para ser usadas de modo subjetivo e doméstico. Os elementos do asfalto e da praia, presentes nos diversos trabalhos, encarnam a imagem metafórica das duas principais áreas coletivas no Brasil: a rua e a praia.”

A exposição, que ocorreu no MASP, escolheu retomar o uso dos cavaletes como mais uma oportunidade de ecoar a ausência do aparato na atual configuração do museu. Os cavaletes foram utilizados aqui de uma nova forma: configuravam uma espécie de labirinto que definia espaços por onde o público caminhava para encontrar as obras dos artistas. Os cavaletes, ao invés de receberem obras, foram recobertos de plotagens coloridas que ora traziam textos, ora imagens, sempre em vinil transparente, o que construía uma ambiência de filtros de luz. Apesar de gerar um efeito interessante no espaço, podemos avaliar que esta forma de utilização não tenha produzido um discurso claro, político, para o público em geral. Afinal, o cavalete de Lina Bo Bardi só faz sentido como objeto por carregar um poderoso discurso curatorial, diretamente ligado à forma como ele foi criado para funcionar. Renato Anelli, em artigo que analisa e elogia as conquistas da X Bienal de Arquitetura de maneira geral, faz uma ressalva justamente a isso: 
A exposição no Masp, apesar da qualidade da temática e abordagem, acentua a indignação com o tratamento que os "cavaletes de cristal", suportes expositivos transparentes concebidos por Lina para a pinacoteca do museu, vem tendo desde o seu banimento na década de 1990. Apesar da intenção de homenagem, sua disposição formando paredes transparentes que chegam perto de configurar pequenas "salas" em meio à amplitude do espaço do museu é somente uma caricatura da grandeza original. Momento difícil para o Masp, que defende o cercamento do vão livre como modo de enfrentamento do aumento de criminalidade e do consumo de drogas nesse local. ${ }^{60}$

Em entrevista para essa dissertação, o professor e arquiteto Guilherme Wisnik comenta que, apesar de o objetivo da retomada do cavalete ter sido colocá-lo novamente à evidência, de fato, talvez, a maneira com que foi feita tenha deixado uma certa ambiguidade no ar.

Tivemos a oportunidade de usar o MASP para fazer aquela exposição que tinha como uma das personagens era a própria Lina. (...) Eram cinco grandes personagens que fizeram parte de acontecimentos cruciais na arte no brasil no fim dos anos 60 e começo dos 70. Aquele hall cívico do MASP onde a exposição aconteceu é um lugar muito interessante. Não é o lugar onde os cavaletes ficavam, então já havia um deslocamento. Se íamos fazer uma exposição no MASP, queríamos logo de saída usar o cavalete como um discurso - tirá-los do depósito e colocá-los de novo em exposição. Mas justamente num sentido deslocado, pois a ausência de quadros sobre aqueles vidros falava um pouco dessa ausência - era uma espécie de discurso sobre a ausência, a evocação de um fantasma do cavalete. Eu sei quemuitos não entenderam assim, e não gostaram. Os mais puristas acharam aquilo uma blasfêmia. Penso que tudo bem, são posições válidas. Mas nossa intenção era essa: trazer o aspecto fantasmático do cavalete e criar com ele um labirinto, que obviamente não era algo que Lina faria. O labirinto era a grande obsessão de Hélio Oiticica. A obra toda dele fala sobre essa ideia de labirinto, que tem a ver com o espaço da favela, e isso não está nem um pouco longe das questões de Lina. Então construir um labirinto com o sentido de estabelecer um diálogo.

Comentamos então que o que parece ter incomodado professor Renato Anelli é o fato de que talvez não tenha ficado evidente essa ideia do fantasma, da ausência, por conta de o cavalete estar de alguma forma coberto de conteúdo - seja conteúdo cromático simplesmente, ou de texto. Isso pode ter gerado uma certa ambiguidade, já que o fato é que naquela situação o cavalete, além de labirinto, virou sim suporte - não para quadros, mas para textos e imagens plotadas. Em resposta à essa especulação, Wisnik responde:

A situação era ambígua mesmo. Não ficou um discurso explícito sobre essa ausência, porque também não era exatamente essa a nossa intenção. De fato era uma exposição com conteúdo [sobre os cavaletes] - não conteúdos originais mas reproduções, e buscávamos muito colocar Lina em diálogo com outros artistas. Mas pode ser que Anelli tenha de fato razão. Creio que é uma questão em aberto.

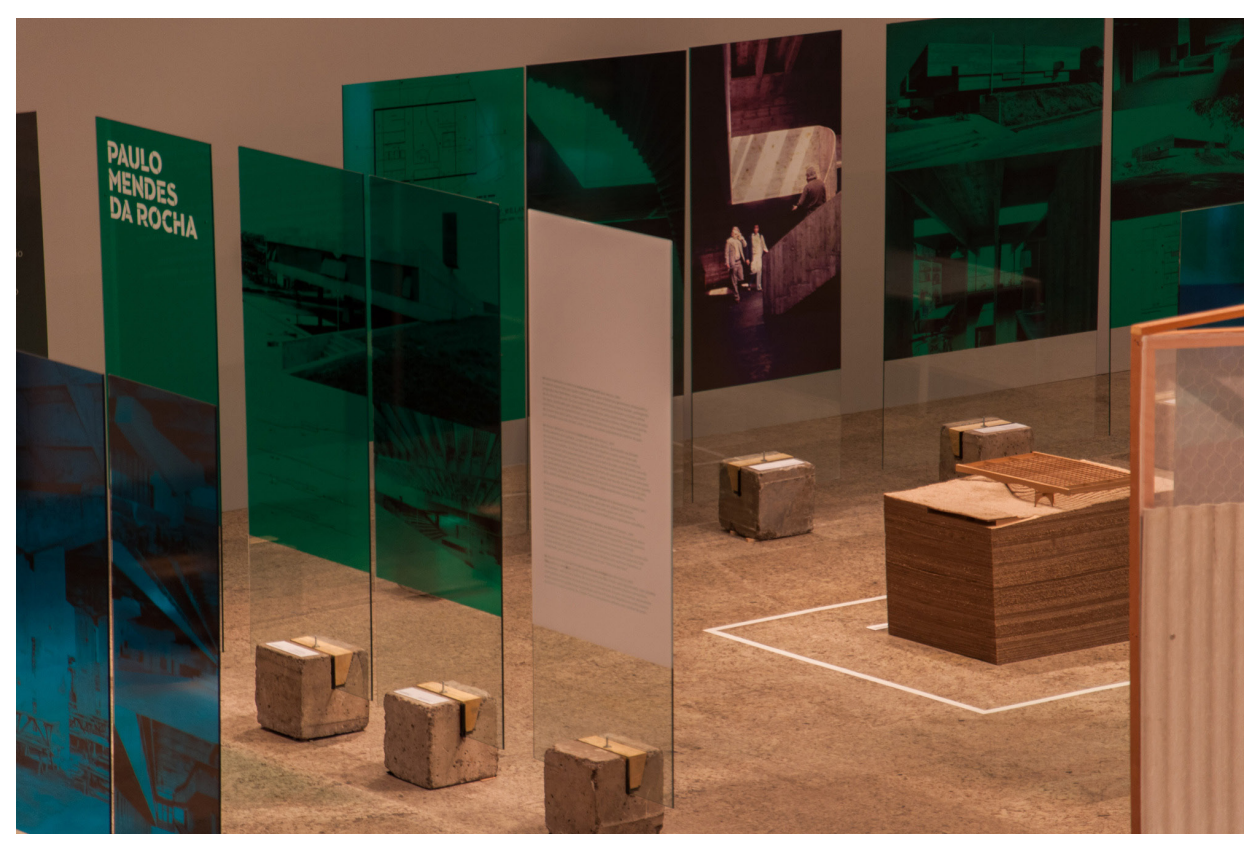

Fonte: Archidaily - http://www.archdaily.com.br/br/01-155619/modosde-atravessar-masp-museu-de-arte-de-sao-paulo-assis-chateaubrian-
d/5293a8eae8e44eba3c00003e 

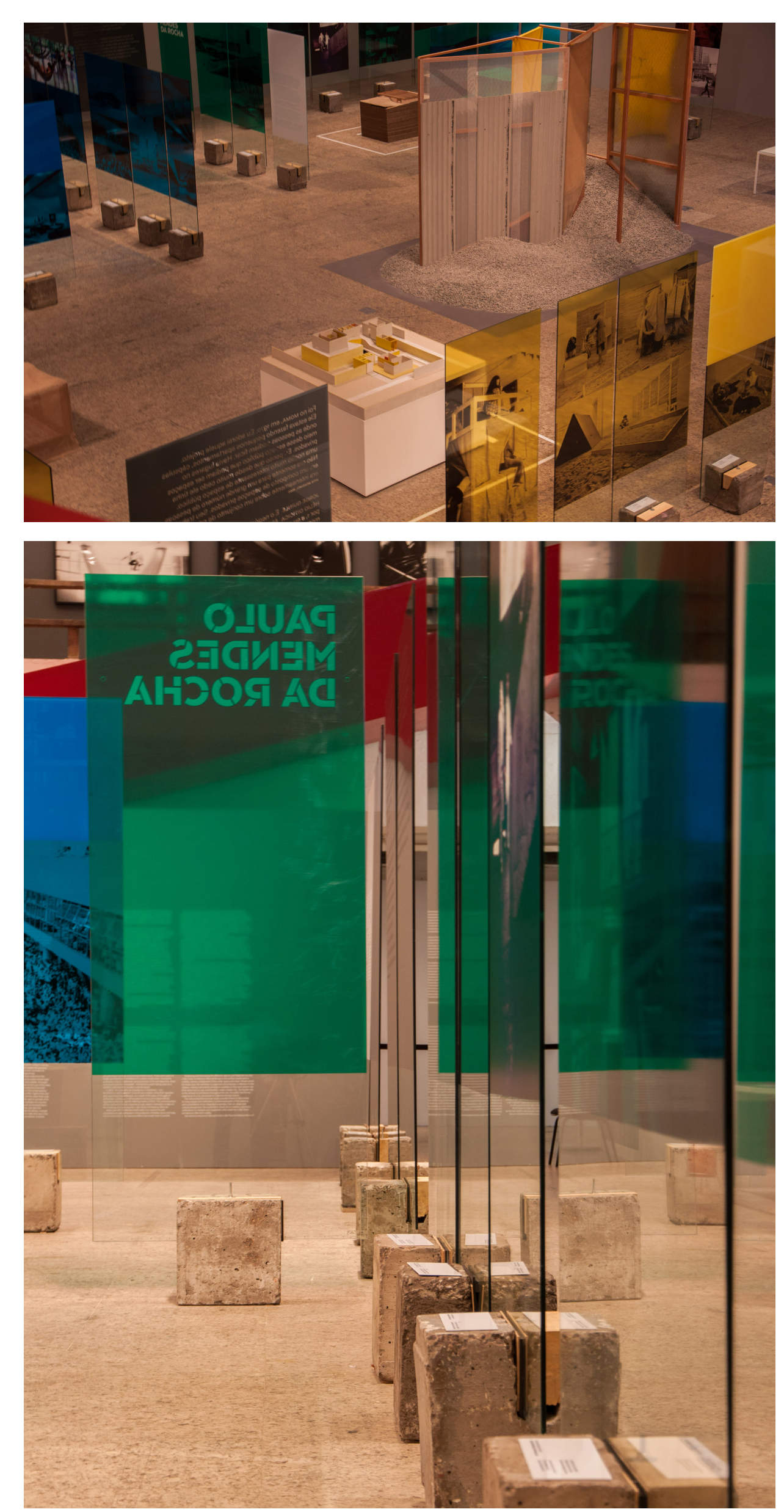

2014 - São Paulo

Maneiras de Expor -

Arquitetura Expositiva de Lina Bo Bardi

Com curadoria de Giancarlo Latorraca, a mostra realizada no $\mathrm{Mu}-$ seu da Casa Brasileira se dedicou, exclusivamente, a olhar as mais variadas formas de exposição desenvolvidas por Lina ao longo de sua carreira. Destacou-se a importância de seu papel na construção de um pensamento legitimamente conectado às questões brasileiras e que se consolidou como forte referência para as próximas gerações. Foi a primeira vez que seus displays foram olhados de forma abrangente, numa montagem que conseguiu reproduzir, com precisão e sem excessos, ambientações criadas pela arquiteta para algumas de suas mais marcantes exposições, como "Bahia no Ibirapuera", "A Mão do Povo Brasileiro" e, é claro, os cavaletes do MASP. No ambiente dedicado a esse tema, a curadoria conseguiu simular a amplitude do espaço da pinacoteca quando ainda estava tomada pelos cavaletes com a plotagem de uma foto em grande escala na parede do fundo, e a sobreposição de alguns cavaletes à frente. Sobre o cavalete mais ao centro, foi projetado um vídeo que oferecia ao público um passeio pelo espaço da pinacoteca, vivo e cheio de pessoas, na companhia do arquiteto Aldo van Eyck, conhecido defensor da museografia de Bo Bardi.

Sobre a forma colo Lina desenvolvia seus sistemas expositivos, o curador comenta:

A construção de suas exposições e dos 'ambientes para fruição e vivência de conteúdos', considerados aqui como as áreas públicas dos museus, ocorreu inicialmente em projetos de caráter mais temporário, contidos no âmbito interno da arquitetura. Foi o caso do primeiro Masp da 7 de Abril, instalado em andares de um edificio existente, e do Museu de Arte Moderna da Bahia (MAMB), instala- 

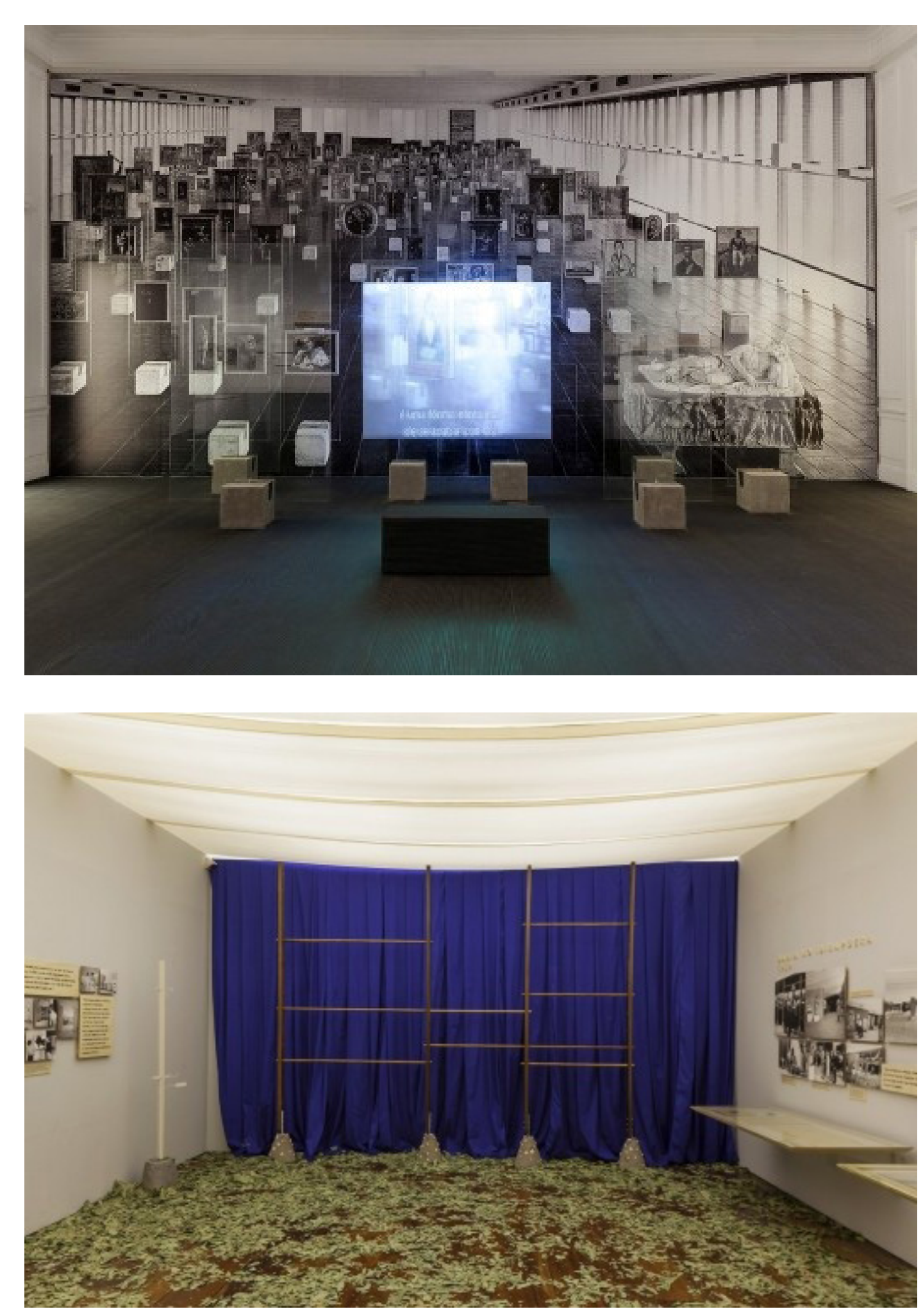

Exposição "Maneiras de expor", curadoria de Giancarlo Latorraca, Museu da Casa Brasileira. Foto Renato Parada. Fonte: http://www.vitruvius.com.br/revistas/read/arquitextos/15.173/5335 do no foyer do Teatro Castro Alves, quase de improviso, sintetizando as necessidades imediatas e mínimas para a operação de um modelo de museu vivo. ${ }^{61}$

A exposição é exitosa em apresentar para o público a coerência na evolução dos displays de Lina em cada situação expográfica, ainda oferecendo uma experiência vivencial potente, rara de ser encontrada em uma exposição documental.

Um catálogo com excelentes textos e rico em imagens completa a exposição, deixando um registro desse importante olhar panorâmico sobre os espaços expositivos desenvolvidos por Lina. 
2017 - Kassel - Alemanha

$14^{a}$ Documenta de Kassel

Ainda em fase embrionária, a Documenta, uma das mais importantes mostras de arte do mundo, realizada a cada cinco anos em Kassel, na Alemanha, terá como curador desta edição o polonês Adam Szymcyk. Introduzido com maior profundidade à obra de Lina Bo Bardi em sua última visita ao Brasil, o curador declarou à Folha de S. Paulo:

Ela é interessante porque foi uma pensadora, ativista e arquiteta que fez muito para moldar a realidade social a partir da construção de museus. O que ela fez no Masp é um gesto corajoso de defesa do espaço público. Se há um papel para os museus aqui é que eles sejam espaços de acolhimento. ${ }^{2}$

O curador destacou que pretende se apropriar da "arquitetura de proposições e manifestos" de Lina como princípio organizado da próxima edição da Documenta, e fez uma declaração em defesa da atualidade e pertinência dos extintos cavaletes:

Ela criou com esses suportes imateriais um confronto cara a cara entre cidadão e obra de arte. Não tinha o caráter linear dos museus. É um campo aberto, e o fato de todos nos lembrarmos disso significa que esses conceitos não são anacrônicos. ${ }^{63}$
4.2 Deslocamentos do cavalete:

o que fica pelo caminho

O levantamento desses projetos evidencia a frequência com que o cavalete volta à tona para ser usado como maneira de refletir sobre formas de expor ou propor críticas à sua supressão. Fica claro, com isso, que ele ainda é encarado como um objeto que detém uma importante carga discursiva, que não se perdeu mesmo após tantos anos passados. É importante, porém, evidenciar que em quase todos os projetos em que o cavalete é trazido à tona há uma artificialidade e limitação no resultado, que estão ligados ao fato de que falta, nessas montagens alternativas, um elemento que tem tanta importância quanto o próprio display: o edifício do MASP. O projeto do cavalete dificilmente pode manter sua potência se transferido para outro espaço que não aquele para o qual foi elaborado - afinal, é um projeto total, um pensado para o outro. A experiência de ter o contato com a cidade e o reconhecimento da continuidade dalinguagem de desenho dos espaços são elementos-chave que criam a potência da proposta museográfica do MASP.

\footnotetext{
62 in "Próxima Documenta busca inspirações em Lina Bo Bardi". Folha de S. Paulo. Caderno llustrada, 03/10/2014
}

63 Idem. 


\section{O RETORNO DOS CAVALETES - \\ UM FUTURO QUE DEPENDE DO PASSADO}

Deixem que o MASP continue a ser uma exceção maravilhosa à regra e à

prática errada.

Aldo van Eyck

Durante o desenvolvimento dessa dissertação, constava como capítulo de fechamento a ser desenvolvido um intitulado "Especulações sobre um possível retorno do cavalete”, no qual iriamos refletir sobre a possibilidade de retomar essa museografia e os desafios que essa proposta traria. Para nossa surpresa, a especulação tornou-se fato, e a nova diretoria do MASP empossada no final de 2014 tomou para si como objetivo primeiro o de restabelecer a vocação original do museu, o que inclui trazer de volta os famosos cavaletes de cristal e deixar a luz voltar a entrar no museu. O destino desse capítulo de considerações finais passou então de discussão hipotética para um olhar sobre desafios de um futuro próximo.

Em outubro de 2014, depois de anos em crise, anunciou-se o início de uma grande mudança do quadro diretivo do MASP. O empresário Heitor Martins, ex-diretor da Fundação Bienal, assumiu como novo presidente e, em novembro, o curador e editor Adriano Pedrosa, um dos nomes mais conceituados da área do país, assumiu o cargo de diretor artístico da instituição. Diferentemente do padrão antes adotado pelo museu de se ter um curador geral, a direção decidiu por fragmentar as atividades entre vários curadores, cada um dedicado a uma área de especialidade, já que a coleção do MASP é de grande diversidade. Pedrosa coordenará, então, a equipe de curadores e 
o desenvolvimento dos projetos de exposições. Já em sua primeira declaração à mídia, o curador deixou claro que não se pode propor um novo futuro para a instituição, ignorando seu passado como vem sendo feito nas ultimas décadas. E, agindo nesse sentido, propôs a retomada dos cavaletes e a remoção das paredes que selam as janelas do museu em todos os andares. A ideia, porém, não é simplesmente recuperar o passado do espaço, mas repensar de que maneira é possível fazê-lo com coerência em relação ao atual momento histórico, em termos técnicos e discursivos. Em entrevista à Folha de S. Paulo, Pedrosa afirma: "Voltar com os cavaletes é um gesto genuíno por achar que isso tem uma radicalidade, uma subversão. Muitos de nós não conviveram com eles, e há um desejo que voltem. Não é um gesto de marketing, mas vai ser nossa grande ação agora.”44

Logo de início, um grandes desafio técnico começou a se apontar, e ele serve de exemplo do que terá de ser enfrentado para que essa reforma seja, de fato, bem sucedida. Pedrosa relatou, em breve encontro realizado em razão dessa dissertação em janeiro, junto com o arquiteto integrante da equipe, Martin Corullon, que um primeiro obstáculo nesse momento inicial de recuperação dos cavaletes tem a ver com a necessidade de assegurar a integridade das obras - mais especificamente, proteger sua superfície de possíveis toques ou intervenções por parte do público. É sabido que a disposição original das obras, espalhadas pela pinacoteca, conformando estreitos corredores, acaba por gerar uma situação em que as peças ficam mais vulneráveis, pois é mais difícil a vigilância dar conta de um espaço tão fragmentado. Nos museus tradicionais, a organização perimetral dos quadros nas salas permite um controle mais claro de tudo o que está acontecendo em volta. De forma a permitir o retorno dos cavaletes assegurando a integridade das obras, a equipe está estudando a instalação de vidros antirreflexo em boa parte delas. Dessa forma, as pinturas estariam protegidas de eventuais toques em sua superfície. Esses vidros

\footnotetext{
64 PEDROSA, A. Folha de S. Paulo - Caderno llustrada, 09/10/2014
}

especiais serão embutidos na moldura e, por seu caráter não reflexivo, sua presença quase não é notada. Aqui entra o segundo nível de dificuldades enfrentado: para que a invisibilidade dessa película vítrea seja garantida, é necessário um rigoroso controle da incidência da iluminação ao redor da obra a fim de que não haja pontos de reflexão. Com a desejada reabertura das janelas, porém, haverá novamente luz banhando o salão da pinacoteca por ambos os lados. Essas luzes laterais poderão criar manchas reflexivas nesses vidros que recobrem as obras - o que atrapalharia, em muito, a observação das mesmas. Para isso, a equipe começa a estudar, também, possíveis soluções que amenizem a incidência da luz solar no espaço, sem impedir o contato visual entre interior e exterior. Corullon destaca que, além da dificuldade de controlar a luz que vem de fora, é também um desafio criar um sistema de iluminação satisfatório para cada obra - já que os cavaletes, em sua disposição original, se encontram soltos no espaço e o grid do teto é mais adequado para resolver exibições distribuídas em salas. Com os cavaletes dispostos de forma irregular, uma luz que é posicionada para iluminar com sucesso um quadro pode estar gerando sombra ou reflexo em outro.

É com esses problemas em mão, e muitos outros por vir, que a equipe procura uma forma de dar os primeiros passos em direção a uma desafiante recuperação da vocação original do MASP, respeitando as necessárias regras de conservação - porém, não negligenciando o discurso do museu em detrimento de tais normas.

Enquanto dá andamento ao processo de recuperação da pinacoteca, Pedrosa já tem em cartaz sua primeira exposição no museu, intitulada MASP em Processo. Sobre ela, o curador afirma:

MASP em processo, ocupando o primeiro andar e o subsolo, é a primeira mostra pública nessa nova etapa, espécie de prólogo ou ensaio de transição, ela não configura uma exposição tradicional, acabada, e com lista de obras expostas predefinida. Ao contrário, o que será revelado ao público, como o nome indica, é justamente 
o processo - de montagem, de pesquisa do acervo e do redescobrimento da arquitetura do museu. ${ }^{65}$

Essa mostra, que organiza as obras a partir de uma mescla de cronologia e gêneros, evidencia trabalhos que não costumam sair da reserva técnica. Sua montagem estará em processo até o fim do período da exposição, com obras sendo incorporadas semanalmente a partir de escolhas do próprio público. É uma primeira oportunidade de voltar a criar um vínculo real e de participação com os visitantes do museu, estreitando sua intimidade com a coleção.

Além dessa mostra, outro espaço mobiliza a atenção daqueles que visitam o espaço: o subsolo do MASP. Apesar de ser semienterrado na direção da Avenida Paulista, foi concebido como um grande salão aberto para as outras três laterais, com entrada abundante de luz natural - situação possibilitada pelo grande desnível do terreno em relação ao Vale do Anhangabaú. Este salão, que estava inteiramente selado desde a reforma, começa a ter suas paredes falsas removidas, permitindo, novamente, o contato com a luz e a cidade. É um processo emocionante de acompanhar, como se um gesso que há tempos imobiliza um membro estivesse, finalmente, sendo retirado - dando chance à respiração da pele e ao movimento.

A possibilidade de retomar, de maneira crítica, essa forma de exposição pode ser fecunda pois irá produzir um maior entendimento sobre suas origens e abrirá chance para que o debate em torno de sua atualidade ganhe corpo num momento em que talvez estejamos todos mais preparados para lidar de forma produtiva com sua potência e ousadia.

Em entrevista concedida para essa dissertação em agosto, antes de sabermos dos novos caminhos do MASP, o professor e arquiteto Guilherme Wisnik traça uma análise sobre as especificidades do momento histórico que estamos atravessando, e como esse pode ser um momento favorável e coerente para que o museu volte a ter sua voz:

65 http://masp.art.br/masp2010/exposicoes_integra.php?id=177\&periodo_menu=cartaz
Acredito que todos esses exemplos de projetos que estão olhando hoje para o cavalete que você me apresentou aqui são bons sinais. É também sempre bom ser otimista. Assim como eu acho que o Brasil não tinha espaço público e agora começa a ter. A noção de espaço público sequer existia na cidade até pouco tempo - é tudo sempre gradeado, fechado, e ninguém dava a mínima para ao espaço urbano. Agora as coisas estão mudando, as manifestações, a Praça Roosevelt, o movimento para transformar o Minhocão num parque, tudo isso são sinais muito positivos de uma revisão total do que é a esfera pública, do que é nosso direito, do que é mobilidade, e eu sou extremamente otimista em relação a tudo isso. Acho que por mais que a política demore mais para incorporar esses dados, as pressões sociais estão nas ruas. E acredito que dá para pensar a mesma coisa em relação a esse seu tema. De alguma maneira ficamos durante duas décadas muito vítimas do argumento neoliberal de que não há escapatória para essas lógicas conservadoras e acho que o momento que a gente vive agora é de crítica em relação a isso. Assim como eu acho que é possivivel a médio prazo simplesmente o minhocão deixar de ser um lugar para carros, e a consequência é um caos de trânsito na cidade, mas ainda sim isso pode acontecer e ser positivo (aliás essa hipótese era impensável há cinco anos atrás), eu acho que o MASP pode ser objeto desse tipo de disputa. Estamos voltando a ter uma consciência sobre a importância daquele que é um patrimônio único. Temos o exemplo do curador Teixeira Coelho que durante esse ano só de mencionar a possibilidade de gradear o MASP gerou uma revolta grande da população, o que provavelmente não aconteceu na época em que os cavaletes foram retirados. As pessoas agora estão muito mais conscientes do que é direito público. E o MASP é talvez um dos mais fortes espaços públicos. (...) Esse movimento está ligado a uma espécie de zeitgeist.

Há consenso de que, sim, existem muitos problemas técnicos e até conceituais - que podem ser também analisados como resultado de dificuldades técnicas -, que precisam ser revistos e discutidos em re- 
lação ao cavalete de cristal e à configuração arquitetônica da pinacoteca do MASP. No entanto, é necessário enxergar que, dentro da singularidade do projeto museográfico criado por Lina, há a criação de uma nova maneira de se relacionar com a arte. No mundo, diversos museus possuem coleções tão ou mais significativas quanto a do MASP, e o que, cada vez mais, faz com que essas coleções atraiam público hoje - para além do valor das próprias obras - é o desafio de essas instituições criarem um discurso que vá além de, simplesmente, pendurar quadros na parede em ordem cronológica. Os desafios contemporâneos relativos à exposição da arte estão muito ligados à forma como as obras são apresentadas ao público - e a opção por criar uma contranarrativa, que desmonta com as tradições e coloca o público como agente na criação de percursos e pensamentos não poderia ser mais atual. O público não deseja mais ser tratado como leigo, mas como participante, como parte ativa de um processo e não como alguém que precisa de um tutor que indique a maneira certa de se entender o que é apresentado. Essa nova tendência é, em grande parte, fruto da evolução do conceito de entretenimento e cultura - os quais não devem ser ignorados em favor de um gosto passadista pela forma clássica de se apreciar arte, numa estrutura essencialmente elitista e impenetrável para os não familiarizados com esse mundo. Os museus atuais precisam ser, fundamentalmente, generosos e inclusivos. A base para que isso seja possível é transformar a maneira como as obras se relacionam com espaço arquitetônico, público e cidade, reconhecendo e contemplando as especificidades de cada local. São questões que Lina embutiu no cerne de seu projeto para o MASP.

Os desafios que a nova equipe do museu terá que enfrentar para trazer o MASP de volta à sua integridade não serão poucos. A empreitada não poderá adotar uma postura preciosista a partir da qual o que vale é reproduzir, em sua totalidade, o que foi feito no projeto original. O tempo que passou nos deu a oportunidade de olhar, de maneira crítica, para esse projeto, e agora é o momento em que o discurso de Lina poderá se concretizar dentro de novos e necessários parâmetros museais. Para o sucesso do projeto em termos das necessárias condições ideais exigi- das de uma instituição museológica desse porte, é muito provável que mudanças tenham que ser feitas - seja na forma como a luz penetra no edifício, através de películas protetoras ou outro recurso mais estrutural, seja com adaptações do cavalete, para torná-lo, de fato, mais flexível e de fácil movimentação, além de tantas outras questões que surgirão e precisarão de considerável tempo de pesquisa e maturação. O que fica como conclusão desse trabalho é que o MASP precisa ser objeto de requalificação. E essa é a chance de o maior museu da América Latina se estabelecer também como pioneiro de metodologias que olham para o futuro dos museus a partir de seu passado, que já estava muito à frente de seu tempo. De nada vai adiantar simplemente refazer o que jea existia. Os mesmos problemas persistirão. O MASP precisa agora se reinventar, tendo, acima de tudo, consciência de sua origem.

Em 1990, dois anos antes de sua morte, Bo Bardi proferiu uma palestra para alunos da FAU-USP. Em sua fala, destacou exatamente a importância de não ignorar o passado, se nossa intenção é construir um futuro onde possamos reconhecer nossa identidade. E é com esse parágrafo em mente que encerramos essa dissertação, na expectativa de que os próximos passos do museu sejam dados em consonância com o caminho já percorrido.

É preciso se libertar das 'amarras', não jogar fora simplesmente o passado e toda a sua história: o que é preciso é considerar o passado como presente histórico, é ainda vivo, é um presente que ajuda a evitar as várias arapucas... Frente a ele, nossa tarefa é forjar um outro presente, 'verdadeiro', e para isso é necessário não um conhecimento profundo de especialista, mas uma capacidade de entender historicamente o passado, saber distinguir o que irá servir para novas situações de hoje que se apresentem a vocês, e tudo isto não se aprende somente nos livros. Na prática, não existe o passado. O que existe ainda hoje e não morreu é o presente histórico. O que você tem que salvar - aliás, salvar não, preservar - são certas características típicas de um tempo que pertence ainda à humanidade. ${ }^{66}$ 66 Trecho de conferência proferida por Lina Bo Bardi aos estudantes da FAU-USP e transcrita no
texto "Uma aula de arquitetura". Revista Projeto, São Paulo, n. 133, 1990, p. 103-108. 
BIBLIOGRAFIA

ADORNO, T. Prismas, crítica cultural e sociedade. São Paulo: Editora Ática, 1998.

ANDRADE, O. A utopia antropofágica. São Paulo: Globo, 1990.

ANELLI, R. L. S. O Museu de Arte de São Paulo: o museu transparente e a dessacralização da arte. São Paulo: Portal Vitruvius, 2009. Disponível em <http://vitruvius.com.br/revistas/read/arquitextos/10.112/22>. Acesso em: 12 ago. 2014.

.X Bienal de Arquitetura: quando o meio é a mensagem. Portal Vitruvius: 2013. Disponível em: <http://www.vitruvius.com. br/revistas/read/drops/14.074/4967>

Gosto Moderno: o design da exposição e a exposição do design. Arqtexto, Porto Alegre, v.14, UFRGS, 2009, p. 92-109.

AVELLA, A. A. El arquitecto de dos mundos. Lina Bo Bardi, una italiana constructora de Brasil. Santiago: Taller de Letras, v. 44, p. 79-85, 2009.

AVELLA, A. A.; WEYRAUCH, C. S.; FONTES, M. A. R. (Orgs.). Travessias Brasil-Itália. Rio de Janeiro: Eduerj, 2007.

BARDI, P. M. História do MASP. São Paulo: Instituto Quadrante, 1992.

BARDI, L. B. Arte Industrial. In: RUBINO, S.; GRINOVER, M.(Orgs.) Lina por escrito. São Paulo: Cosac Naify, 2009, p.109.

Explicações sobre o Museu de Arte. O Estado de $S$.

Paulo. 5 abr. 1970.

O Museu de Arte de São Paulo: função social dos museus. Revista Habitat. São Paulo: Editora Habitat Ltda., n. 1, p. 17, out./ dez. 1950.

Museu de Arte de São Paulo. São Paulo: Blau, 1997.

Uma Aula de Arquitetura. Revista Brasileira de Arquitetura, Planejamento, Desenho Industrial e Construção. São Paulo: Projeto Editores Associados Ltda., n. 133, p.103 - 108, ago. 1990.

BARKER, E. Contemporary cultures of display. Yale: Yale University Press, 1999.

BELCHER, M. Organización y diseño de exposiciones: su relación con el museo. Gijón: Trea, 1997. 
BENCHETRIT, S; BEZERRA, R.; MAGALHÃES, A. (Orgs.). Museus e comunicação: $a$ exposição como objeto de estudo. Rio de Janeiro: Museu Histórico Nacional, 2010

BLANCO, A. G. La Exposición: un medio de comunicación. Madri: AKAL, 1999.

BUERGEL, R. M. This Exhibition is an accusation: the grammar of display according to Lina Bo Bardi. Afterall, n. 26, 2008. Disponível em: $<$ http://www.afterall.org/journal/issue.26/this-exhibition-is-an-accusation-the-grammar-of-display-according-to-lina-bo-bardi1>. Acesso em: 17 nov. 2013.

CABRAL, M. C. N. O Racionalismo Arquitetônico de Lina Bo Bardi. Dissertação (Mestrado em História) - Departamento de História. Rio de Janeiro: Pontifícia Universidade Católica do Rio De Janeiro, 1996.

CANAS, A. T. MASP: Museu Laboratório - Projeto de museu para a cidade: 1947- 1957. Tese de Doutorado. São Paulo: FAU-USP, 2010.

O MASP: Museu e Cidade em Pietro M. Bardi. São Paulo: Portal Vitruvius. Disponível em: <http://www.vitruvius.com.br/ revistas/read/arquitextos/13.150/4450 > . Acesso em: 21 fev. 2014.

CASSOU, R. de S. C. A cenografia das exposições museográficas de Lina Bo Bardi. Rio de Janeiro: UNIRIO - Laboratório de Estudos do Espaço Teatral e Memória Urbana.

CHIARELLI, T. As funções do curador, o Museu de Arte Moderna de São Paulo e o Grupo de Estudos em curadoria do MAM. Grupo de Estudos em curadoria. São Paulo: MAM, 1998.

CHKLOVSKI, V. Arte como procedimento. Teoria da Literatura - Formalistas Russos. Porto Alegre: Globo, 1998.

CRIMP, D. Sobre as ruínas do museu. São Paulo: Martins Fontes, 2005.

CURY, M. X. Exposição: análise metodológica do processo de concepção, montagem e avaliação. Dissertação de mestrado. São Paulo: ECA, 1999.

Chapecó: Argos, 2005

. Museologia. Marcos Referenciais. Cadernos CEOM.

CZWG. Disponível em: <www.czwg.com>. Acesso em: 19 fev. 2014.

DANTO, A. C. Após o fim da arte. São Paulo: Edusp, 2006.

DEAN, D. Museum exhibition: theory and practice. New York: Routledge, 2001.
DIDI-HUBERMAN, G. O que vemos, o que nos olha. São Paulo: Editora 34, 1998.

ENCICLOPÉDIA Itaú Cultural de Artes e Cultura Brasileira. Disponível em: <http://enciclopedia.itaucultural.org.br/pessoa1646/lina-bo-bardi> Acesso em: 23 jul. 2013.

FERRAZ, M. (Org.). Lina Bo Bardi. São Paulo: Instituto Lina Bo e P. M. Bardi, 1993.

FERRAZ, M. Lina Bo Bardi e a Tropicália. Projeto Design. São Paulo: Arco Editorial. 337 ed. 2008. Disponível em: < http://arcoweb.com.br/projetodesign/artigos/artigo-lina-bo-bardi-e-a-tropicalia-01-03-2008>. Acesso em: 21 nov. 2013

FERREIRA, E.C. Refletindo e inovando a maneira de expor arte. In: Fundação Bienal de São Paulo. XXIII Bienal Internacional de São Paulo - Catálogo Universalis. São Paulo: FBSP, 1996, p.17.

FRY, R. Visão e Forma. Trad. Cláudio Marcondes. São Paulo: Cosac Naify, 2002.

GEIGER, P. As formas do espaço brasileiro. Rio de Janeiro: Jorge Zahar Editor, 2003.

GENETTE, G. Paratexts: threshold of interpretation. Massachusetts: Cambridge University Press, 1997.

GONÇALVES, L. R. Entre Cenografias: o museu e a exposição de arte no século XX. São Paulo: EDUSP/FAPESP, 2004.

GREENBERG, R.; FERGUNSON, B.; NAIRNE, S. (Org.). Thinking about exhibitions. Londres e Nova York: Routledge, 2006.

Remembering exhibitions: from point to line to web. Londres: TATE's Online Research Journal, 2009. Disponível em: <http:// www.tate.org.uk/download/file/fid/7264>. Acesso em: 05 mar. 2014.

GRINOVER, M. Lina Bo Bardi e Glauber Rocha: diálogos para uma filosofia da "práxis", 2010. Disponível em: <http://www.docomomobahia. org/linabobardi_5o/15.pdf >. Acesso em: 14 set. 2013.

GRINOVER, M.; RUBINO, S. (Org.). Lina Por Escrito. São Paulo: Cosac Naify, 2009.

Uma ideia de arquitetura: escritos de Lina Bo Bardi. Dissertação de Mestrado - São Paulo: FAU-USP, 2010.

JORGE, L. A. O Museu de Arte de São Paulo. Revista Arquitetura e Urbanismo. São Paulo: p. 53-63, 1997. 
KIRK, Terry. The Architecture of Modern Italy - Volume II: Visions of Utopia, 1900 - Present. Princeton: Princeton Architectural Press, 2005.

LAVINE, S. D. Exhibiting Cultures: the poetics and politics of museum display. Washington: Smithsonian Books, 1991.

LIMA, Z. Lina Bo Bardi, entre margens e centros. ARQTEXTO, Porto Alegre: UFRGS.v. 14, 2009. Disponível em: <http://www.ufrgs.br/propar/ publicacoes/ARQtextos/pdfs_revista_14/o5_ZL_entre\%2omargens\%20 e\%20centro_070210.pdf>. Acesso em: 22 jul. 2014.

Lina Bo Bardi: Hybrid Modernism. Pós-doutorado - Heyman Center for the Humanities. Nova York: Columbia University, 2006-2010.

LONRENC, J.; SKOLNICK, L.; BERGER, C. What is Exhibition design? Suíça: Rotovision, 2007.

MACHADO, V. R.; SANTOS, F. L. de S. Lina Bo Bardi e a cultura material popular. Salvador: DOCOMOMO, 2009. Disponível em: <http://www.docomomobahia.org/linabobardi_5o/22.pdf >. Acesso em: 12 mar. 2014.

MAHFUZ, E. da C. Traços de uma arquitetura consistente. São Paulo: Portal Vitruvius, 1991. Disponível em: <http://www.vitruvius.com.br/revistas/read/arquitextos/02.016/847>. Acesso em: 23 abr. 2013.

MALDONADO, T. Lo real y lo virtual. Espanha: Gedisa Editorial, 1995.

.Design plus Research, Opening Lecture. Milão, 2000.

MALRAUX, A. O museu imaginário. Lisboa: Edições 70, 2000.

MARSTINE, J. New Museum, Theory and Practice. Oxford: Blackwell, 2006.

MARINCOLA, P. (Org.). What makes a great exhibition? Filadélfia: Philadelphia Exhibitions Initiative, 2006.

MIYOSHI, A. Arquitetura em Suspensão: o edifício do Museu de Arte de São Paulo. São Paulo: Armazém do Ipê, 2011.

Expografias italianas do pós-guerra, o MASP na Rua 7 de Abril e na Avenida Paulista. Campinas: III Encontro de História da Arte - IFCH. Campinas: UNICAMP, 2007. Disponível em: <http:// www.unicamp.br/chaa/eha/atas/2007/MIYOSHI,\%20Alexandre\%20 Gaiotto.pdf>. Acesso em: 23 nov. 2013.

Museografias do MASP. I ENCONTRO DE HISTÓRIA DA ARTE - IFCH. Campinas: UNICAMP, 2005. Disponível em: $<$ http://www.unicamp.br/chaa/eha/atas/2004/MIYOSHI,\%20Alexander\%20Gaiotto\%2o-\%20IEHA.pdf>. Acesso em: 15 nov. 2014.
MIRANDULINA, Maria Moreira Azevedo. Experiência de Lina Bo Bardi no Brasil (1947-1992). Dissertação de Mestrado - FAU-USP, 1995.

MORAIS, F. Chatô: o rei do Brasil. São Paulo: Companhia das Letras, 2013

MOMA Collection. Disponível em: <http://www.moma.org/collection/ object.php?object_id=757. Consultado dia 12 de fevereiro de 2015>. Acesso em: O’NEILL, P.; ANDREASEN, S. Curating subjects. Londres: Open Editions, 2007.

O'DOHERTY, B. No interior do Cubo Branco: a ideologia do Espaço da Arte. São Paulo: Martins Fontes, 2002.

OLIVEIRA, O. Lina Bo Bardi: sutis substâncias da arquitetura. São Paulo: Editora Romano Guerra/Gustavo Gili, 2006.

Repasses: a depredação material e espiritual da obra de Lina Bo Bardi. São Paulo: Portal Vitruvius, 2006. Disponível em: <http://www.vitruvius.com.br/revistas/read/arquitextos/o6.068/387>. Acesso em: 19 nov. 2014

Lina Bo Bardi: Built Works. Barcelona: 2G, 2001.

ORTEGA, C. G. Salvador: a experiência da simplificação - uma premissa para o Museu de Arte de São Paulo. Salvador: DOCOMOMO, 2009. Disponível em: http://www.docomomobahia.org/linabobardi_50/4.pdf. Acesso em: 11 set. 2013.

PEREIRA, J. A. A didática dos museus de Lina Bo Bardi e os conteúdos da modernidade e da identidade local. São Paulo: DOCOMOMO, 2009. Disponível em: <http://www.docomomo.org.br/seminario\%205\%2opdfs/o8oR.pdf >. Acesso em:

EDUFU, 2007.

Lina Bo Bardi: Bahia 1958-1964. Uberlândia:

PIEROBON, M. Z. O Museu de Arte de São Paulo - MASP no contexto do turismo cultural paulistano: imagem e crise - dicotomia entre o real e 0 imaginário. São Paulo: Monografia apresentada ao curso de Turismo da Unesp, 2007. Disponível em: <http://biblioteca.rosana.unesp.br/upload/Pierobon.pdf>. Acesso em: 15 nov. 2014.

PUPPI, S. de O. F. Lina Bo Bardi é o Museu Imaginário de André Mal raux. $9^{\circ}$ Seminário DOCOMOMO Brasil. Brasília: DOCOMOMO, 2011. Disponível em: <http://www.docomomo.org.br/seminario\%209\%20 pdfs/169_M27_RM-LinaBoBardiEoMuseuImaginario-ART_suely_puppi.pdf $>$. Acesso em: 15 nov. 2014

RATTEMEYER, C. (Org.). Exhibiting the New Art: 'Op Losse Schroeven' and 'When Attitudes Become Form' 1969. Londres: Afterall Books, 2011. 
RATTENBURY, A. Exhibition design: theory and practice. Michigan: Studio Vista, 1971.

RISÉRIO, A.; VELOSO, C. (Apres.). Avant-Garde Na Bahia. São Paulo: Instituto L. B. e P. M. Bardi, 1995.

SCHINCARIOL, Z. Através do espaço do acervo: o Masp na 7 de Abril. Dissertação de Mestrado - São Paulo: FAUUSP, 2000.

SERTORIO, P. V. Relação entre arte e o público no MASP: um olhar do presente em direção a 1970. Dissertação (Mestrado em...) - Departamento de... .São Paulo: ECA-USP, 2012.

SHEDROFF, N. Experience Design. London: Experience Design Books, 2009.

STANISZEWSKI, M. A. The Power of Display: $a$ history of exhibition installations at the Museum of Modern Art. Massachusetts: MIT Press, 1998.

SUZUKI, M. (Org.). Tempos de grossura: o design no impasse. São Paulo: Instituto Lina Bo e P. M. Bardi: Fundação Vilanova Artigas, 1994.

Lina e Lucio. Dissertação de Mestrado - São Carlos:

EESC-USP, 2010.

VIERNO, L. R. A modernidade museográfica de Lina Bo Bardi. Taubaté: Universidade de Taubaté - Departamento de Arquitetura, 2002. 